Prepared in cooperation with the California State Water Resources Control Board A product of the California Groundwater Ambient Monitoring and Assessment (GAMA) Program

\title{
Status of Groundwater Quality in the Santa Barbara Study Unit, 2011: California GAMA Priority Basin Project
}

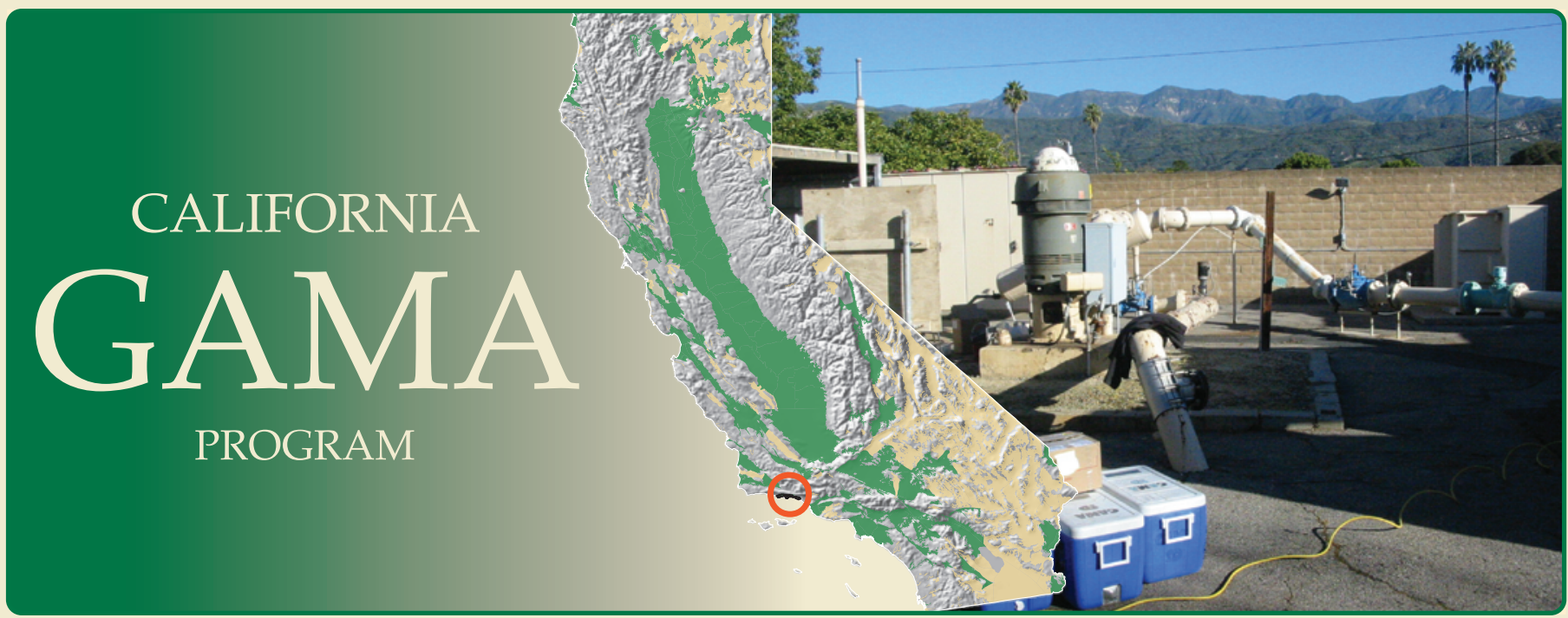

Scientific Investigations Report 2016-5112 
Front Cover Map: Groundwater basins categorized by sampling priority. Location of groundwater basin boundaries from California Department of Water Resources (CDWR, 2003).

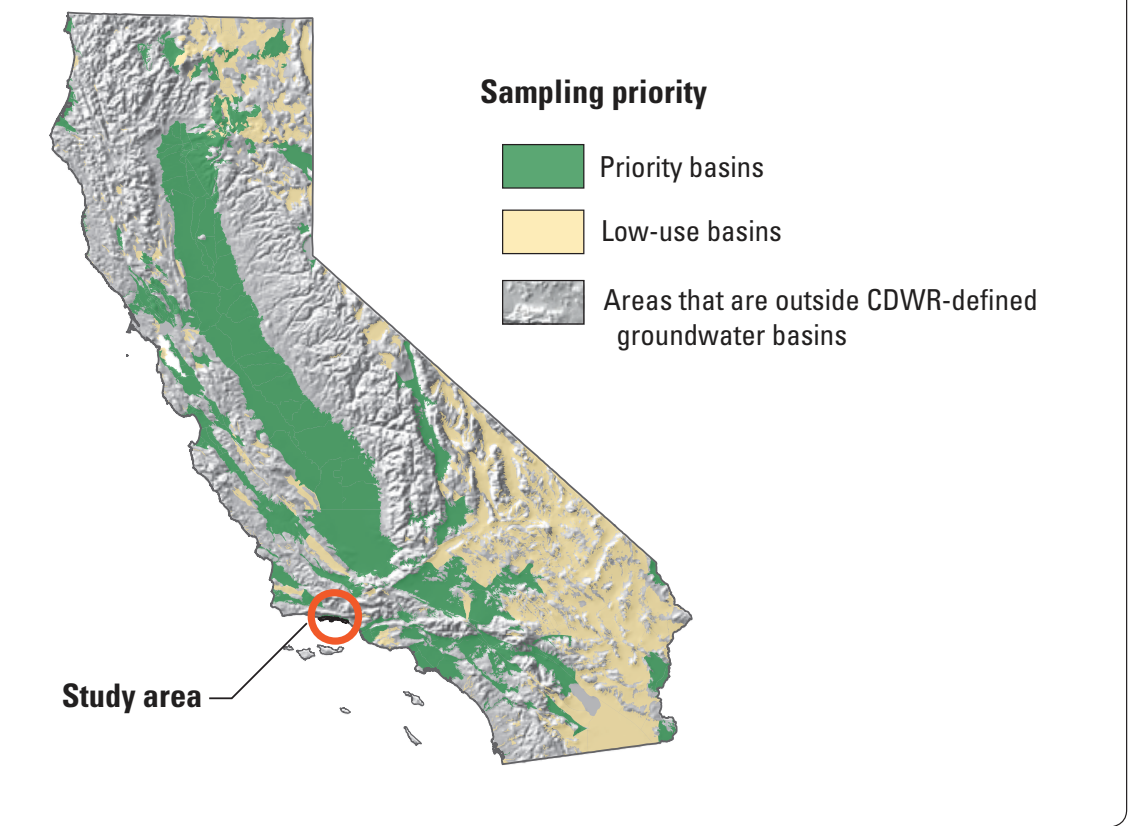

\section{Cover photographs:}

Front cover: Municipal supply well, Santa Barbara County, California. (Photograph taken by Greg Brewster, U.S. Geolgoical Survey.)

Back cover: Historic Cabrillo Boulevard Bridge over Mission Creek, Santa Barbara, California. (Photograph taken by Dara Goldrath, U.S. Geolgical Survey.) 


\section{Status of Groundwater Quality in the Santa Barbara Study Unit, 2011: California GAMA Priority Basin Project}

By Tracy A. Davis and Justin T. Kulongoski

A product of the California Groundwater Ambient Monitoring and Assessment

(GAMA) Program

Prepared in cooperation with the California State Water Resources Control Board

Scientific Investigations Report 2016-5112 


\title{
U.S. Department of the Interior SALLY JEWELL, Secretary
}

\section{U.S. Geological Survey Suzette M. Kimball, Director}

\author{
U.S. Geological Survey, Reston, Virginia: 2016
}

For more information on the USGS - the Federal source for science about the Earth, its natural and living resources, natural hazards, and the environment—visit http://www.usgs.gov or call 1-888-ASK-USGS.

For an overview of USGS information products, including maps, imagery, and publications, visit http://www.usgs.gov/pubprod/.

Any use of trade, firm, or product names is for descriptive purposes only and does not imply endorsement by the U.S. Government.

Although this information product, for the most part, is in the public domain, it also may contain copyrighted materials as noted in the text. Permission to reproduce copyrighted items must be secured from the copyright owner.

Suggested citation:

Davis, T.A., and Kulongoski, J.T., 2016, Status of groundwater quality in the Santa Barbara Study Unit, 2011: California GAMA Priority Basin Project: U.S. Geological Survey Scientific Investigations Report 2016-5112, 70 p., http://dx.doi.org/10.3133/sir20165112. 


\section{Acknowledgments}

The authors thank the following cooperators for their support: the California State Water Resources Control Board, Lawrence Livermore National Laboratory, the California Department of Public Health, and the California Department of Water Resources. Funding for this work was provided by the State of California bonds authorized by Proposition 50 and administered by the California State Water Resources Control Board.

We especially thank the cooperating well owners and water purveyors for their generosity in allowing the U.S. Geological Survey to collect samples from their wells.

\section{Contents}

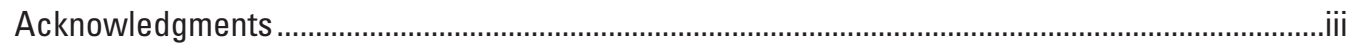

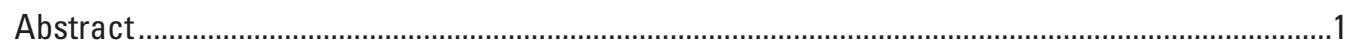

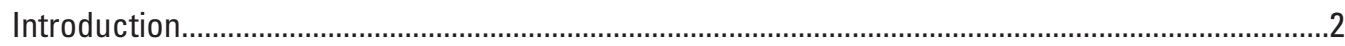

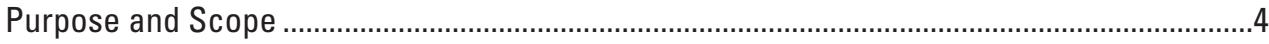

Hydrogeologic Setting of the Santa Barbara Study Unit ...........................................................

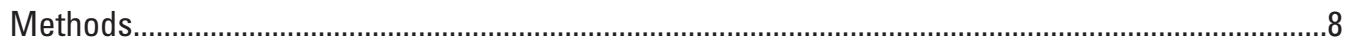

Water-Quality Benchmarks and Relative-Concentrations ....................................................

Datasets for Status Assessment.........................................................................................

Data for Grid-Based Calculations of Aquifer-Scale Proportions ........................................

Data for Spatially Weighted Calculations of Aquifer-Scale Proportions .........................10

Selection of Constituents for Additional Evaluation ...........................................................10

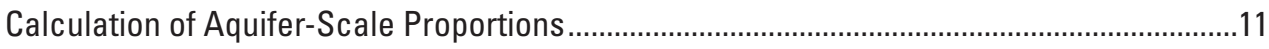

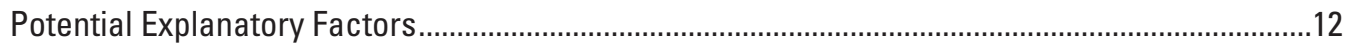

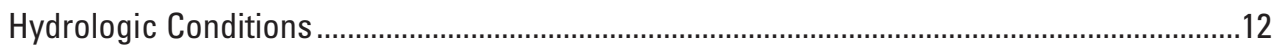

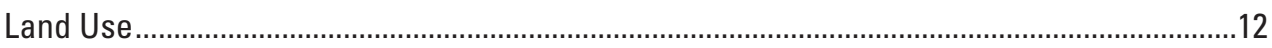

Formerly Leaking Underground Fuel-Tank and Septic-Tank Densities....................................13

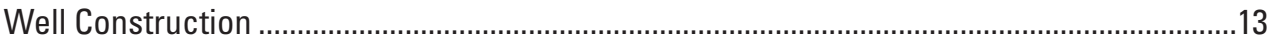

Groundwater Age

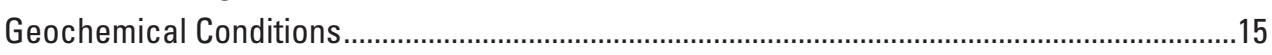

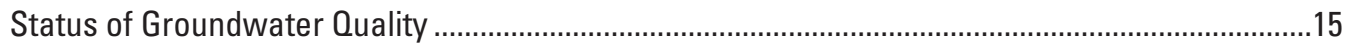

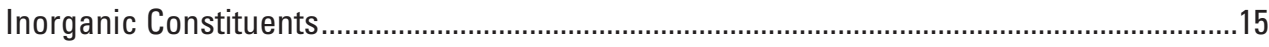

Trace Elements and Major and Minor lons ................................................................19

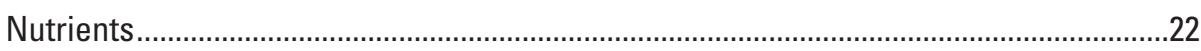

Uranium and Radioactive Constituents...................................................................22

Inorganic Constituents with Aesthetic-Based Benchmarks ..........................................22

Chloride, Sulfate, and Total Dissolved Solids .......................................................24

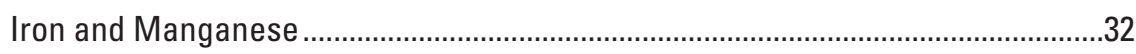

Organic and Special-Interest Constituents ........................................................................

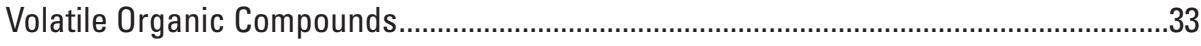

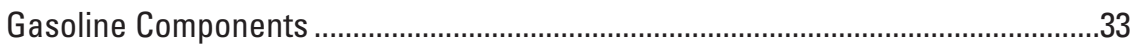

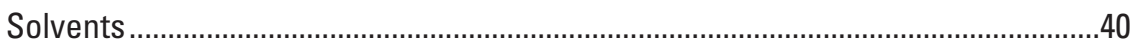

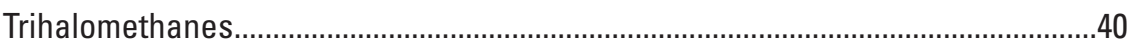

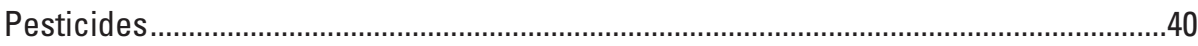

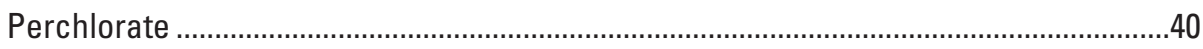




\section{Contents-Continued}

Summary

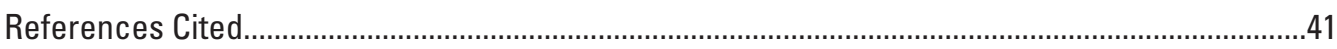

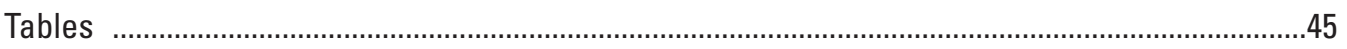

Appendix 1. Additional Information about Data used in the Status Assessment ..........................53

Selection of California Department of Public Health and U.S. Geological Survey Data.........53

Comparison of California Department of Public Health and USGS-GAMA Data .....................53

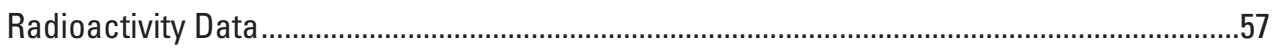

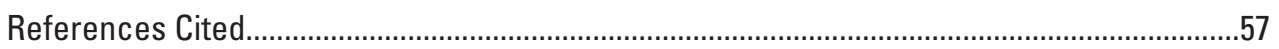

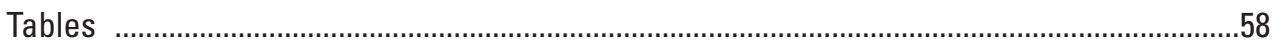

Appendix 2. Attribution of Potential Explanatory Factors .............................................................59

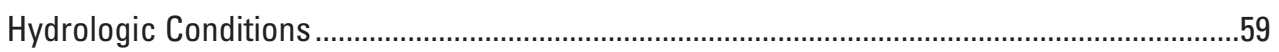

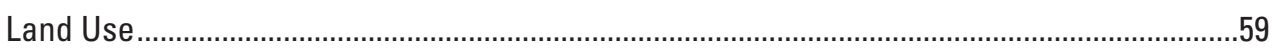

Formerly Leaking Underground Fuel-Tank and Septic-Tank Densities...................................59

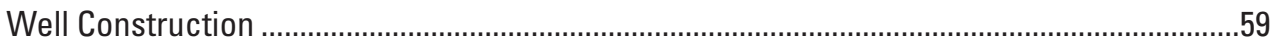

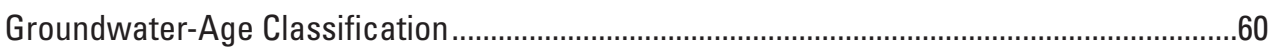

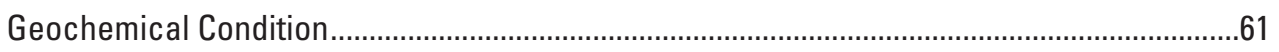

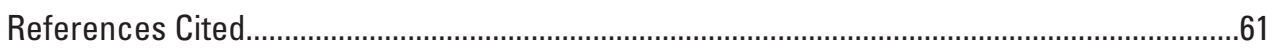

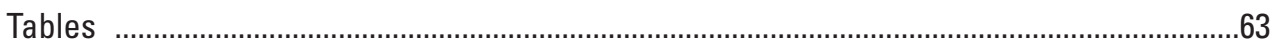

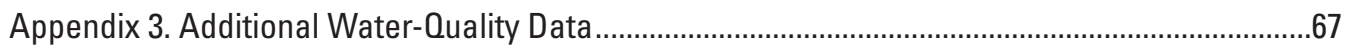

Results for Dissolved Noble Gases and Modeled Recharge Temperatures...........................67

Results for Isotopic Analyses of Boron and Strontium .....................................................67

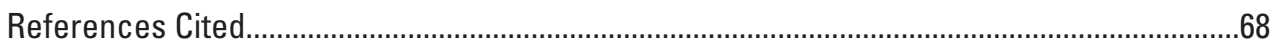

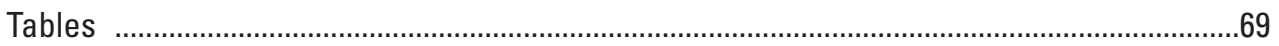

\section{Figures}

1. Map showing the hydrogeologic provinces of California and the location of the Santa Barbara study unit, 2011, California Groundwater Ambient Monitoring and Assessment Priority Basin Project.

2. Map showing land use, California Department of Water Resources-defined groundwater basins, and locations and identifiers for U.S. Geological Survey (USGS) grid, California Department of Public Health grid, and USGS understanding sites, Santa Barbara study unit, 2011, California Groundwater Ambient Monitoring and Assessment Priority Basin Project.

3. Geologic map showing the Santa Barbara study unit, 2011, California Groundwater Ambient Monitoring and Assessment Priority Basin Project.

4. Ternary diagram showing proportions natural, agricultural, and urban land use for U.S. Geological Survey (USGS) grid and USGS understanding sites, Santa Barbara study unit, 2011, California Groundwater Ambient Monitoring and Assessment Priority Basin Project

5. Graph showing well depths, depths to top-of-perforations, and perforation lengths for U.S. Geological Survey (USGS) grid and USGS understanding sites, Santa Barbara study unit, 2011, California Groundwater Ambient Monitoring and Assessment Priority Basin Project 


\section{Figures-Continued}

6. Graphs showing groundwater age classification, Santa Barbara study unit, 2011, California Groundwater Ambient Monitoring and Assessment Priority Basin Project, in relation to the number of sites in each class and the well depth and depth to top-ofperforations.

7. Maps showing geochemical conditions in the Santa Barbara study unit, 2011, California Groundwater Ambient Monitoring and Assessment Priority Basin Project: redox classifications at U.S. Geological Survey (USGS) grid and USGS understanding sites; and pH values at USGS grid, California Department of Public Health (CDPH) grid, USGS understanding, and other CDPH sites....

8. Graph showing maximum relative-concentrations at U.S. Geological Survey grid and California Department of Public Health grid sites for detected constituents, by constituent class, Santa Barbara study unit, 2011, California Groundwater Ambient Monitoring and Assessment Priority Basin Project.

9. Graphs showing relative-concentrations at U.S. Geological Survey grid and California Department of Public Health grid sites in the Santa Barbara study unit, 2011, California Groundwater Ambient Monitoring and Assessment Priority Basin Project for selected inorganic constituents with health-based benchmarks, and aestheticbased benchmarks.

10. Maps showing relative-concentrations in groundwater at U.S. Geological Survey (USGS) grid, California Department of Public Health (CDPH) grid, USGS understanding, and other CDPH sites, Santa Barbara study unit, 2011, California Groundwater Ambient Monitoring and Assessment Priority Basin Project, of boron and fluoride ......20

11. Map showing relative-concentrations of nitrate at U.S. Geological Survey (USGS) grid, California Department of Public Health (CDPH) grid, USGS understanding, and other CDPH sites, Santa Barbara study unit, 2011, California Groundwater Ambient Monitoring and Assessment Priority Basin Project.

12. Maps showing relative-concentrations at U.S. Geological Survey (USGS) grid, California Department of Public Health (CDPH) grid, USGS understanding, and other CDPH sites, Santa Barbara study unit, 2011, California Groundwater Ambient Monitoring and Assessment Priority Basin Project of total dissolved solids; sulfate; chloride; iron; and manganese..

13. Piper diagrams showing U.S. Geological Survey (USGS) grid and USGS understanding sites, grouped by total dissolved solids concentrations, Santa Barbara study unit, 2011, California Groundwater Ambient Monitoring and Assessment Priority Basin Project.

14. Graph showing stable isotope ratios of hydrogen and oxygen for U.S. Geological Survey (USGS) grid and USGS understanding sites, by groundwater total dissolved solids relative-concentration, Santa Barbara study unit, 2011, California Groundwater Ambient Monitoring and Assessment Priority Basin Project..

15. Graph showing detection frequencies and maximum relative-concentrations of organic and special-interest constituents detected at U.S. Geological Survey grid sites, Santa Barbara study unit, 2011, California Groundwater Ambient Monitoring and Assessment Priority Basin Project.

16. Graphs showing groundwater data of selected organic and special-interest constituents at U.S. Geological Survey grid sites, Santa Barbara study unit, 2011, California Groundwater Ambient Monitoring and Assessment Priority Basin Project: detection frequencies and relative-concentrations. 


\section{Figures-Continued}

17. Maps showing relative-concentrations at U.S. Geological Survey (USGS) grid, USGS understanding, and California Department of Public Health sites, Santa Barbara study unit, 2011, California Groundwater Ambient Monitoring and Assessment Priority Basin Project, of MTBE, solvents, chloroform, simazine and perchlorate .........35

1-1. Map showing locations of U.S. Geological Survey (USGS) grid, California Department of Public Health grid, and USGS understanding sites and grid cells, Santa Barbara study unit, 2011, California Groundwater Ambient Monitoring and Assessment Priority Basin Project.

1-2. Graph showing paired inorganic constituent concentrations from sites sampled by U.S. Geological Survey, January 24, 2011-February 16, 2011, and by California Department of Public Health, January 24, 2008-January 23, 2011, Santa Barbara study unit, 2011, California Groundwater Ambient Monitoring and Assessment Priority Basin Project.

1-3. Piper diagram showing selected inorganic data from U.S. Geological Survey sites and California Department of Public Health sites for the Santa Barbara study unit, 2011, California Groundwater Ambient Monitoring and Assessment Priority Basin Project

\section{Tables}

1. Classifications by relative-concentrations of organic, special-interest, and inorganic constituents.

2. Summary of constituent groups and number of constituents sampled for the Santa Barbara study unit, 2011, California Groundwater Ambient Monitoring and Assessment Priority Basin Project.

3. Comparison of the number of compounds and median method detection limits, by constituent class, for data stored in the California Department of Public Health database and data collected for the Santa Barbara study unit, 2011, California Groundwater Ambient Monitoring and Assessment Priority Basin Project.

4. Number of constituents analyzed and detected at grid sites, by constituent class and benchmark type, Santa Barbara study unit, 2011, California Groundwater Ambient Monitoring and Assessment Priority Basin Project.

5. Constituents reported at concentrations greater than benchmarks historically (March 23, 1984, through January 23, 2008) in the California Department of Public Health database, Santa Barbara study unit, 2011, California Groundwater Ambient Monitoring and Assessment Priority Basin Project.

6. Aquifer-scale proportions from grid-based and spatially weighted methods, Santa Barbara study unit, 2011, California Groundwater Ambient Monitoring and Assessment Priority Basin Project for constituents detected at high relative-concentrations during the most recent 3 years of available data (January 24, 2008 through January 23, 2011); constituents detected at high or moderate relative-concentrations at grid sites; or organic constituents detected at any concentration with detection frequencies greater than 10 percent in samples collected from grid sites

7. Summary of aquifer-scale proportions for inorganic, organic, and special-interest constituent classes, Santa Barbara study unit, 2011, California Groundwater Ambient Monitoring and Assessment Priority Basin Project. 


\section{Tables-Continued}

1-1. Grid-cell number and nomenclature for grid sites used in the status assessment, Santa Barbara study unit, 2011, California Groundwater Ambient Monitoring and Assessment Priority Basin Project.

2-1. Well construction information, land-use data, and other ancillary data for sites, Santa Barbara study unit, 2011, California Groundwater Ambient Monitoring and Assessment Priority Basin Project

2-2. Tritium, ${ }^{14} \mathrm{C}$ data, and groundwater age classifications, Santa Barbara study unit, 2011, California Groundwater Ambient Monitoring and Assessment Priority Basin Project

2-3. Dissolved oxygen concentration, $\mathrm{pH}$, ratio of oxidized and reduced iron, and oxidation-reduction classification Santa Barbara study unit, 2011, California Groundwater Ambient Monitoring and Assessment Priority Basin Project..

3-1. Results for analyses of noble gases by the Lawrence Livermore National Laboratory and modeled recharge temperatures for samples collected for the Santa Barbara study unit, 2011, California Groundwater Ambient Monitoring and Assessment Priority Basin Project.

3-2. Results for isotopic analyses of boron and strontium in water by the U.S. Geological Survey National Research Program Metals Isotope Research Laboratory for samples collected for the Santa Barbara study unit, 2011, California Groundwater Ambient Monitoring and Assessment Priority Basin Project.

\section{Conversion Factors}

Inch/Pound to SI

\begin{tabular}{|c|c|c|}
\hline Multiply & By & To obtain \\
\hline \multicolumn{3}{|c|}{ Length } \\
\hline inch (in.) & 2.54 & centimeter $(\mathrm{cm})$ \\
\hline inch (in.) & 25.4 & millimeter $(\mathrm{mm})$ \\
\hline foot $(\mathrm{ft})$ & 0.3048 & meter $(\mathrm{m})$ \\
\hline mile (mi) & 1.609 & kilometer $(\mathrm{km})$ \\
\hline \multicolumn{3}{|c|}{ Area } \\
\hline square foot $\left(\mathrm{ft}^{2}\right)$ & 0.09290 & square meter $\left(\mathrm{m}^{2}\right)$ \\
\hline square mile $\left(\mathrm{mi}^{2}\right)$ & 2.590 & square kilometer $\left(\mathrm{km}^{2}\right)$ \\
\hline \multicolumn{3}{|c|}{ Radioactivity } \\
\hline picocurie per liter $(\mathrm{pCi} / \mathrm{L})$ & 0.037 & becquerel per liter $(\mathrm{Bq} / \mathrm{L})$ \\
\hline picocurie per liter $(\mathrm{pCi} / \mathrm{L})$ & 0.313 & tritium units (TU) \\
\hline
\end{tabular}

Temperature in degrees Celsius $\left({ }^{\circ} \mathrm{C}\right)$ may be converted to degrees Fahrenheit $\left({ }^{\circ} \mathrm{F}\right)$ as follows:

$$
{ }^{\circ} \mathrm{F}=\left(1.8 \times{ }^{\circ} \mathrm{C}\right)+32 .
$$

Temperature in degrees Fahrenheit $\left({ }^{\circ} \mathrm{F}\right)$ may be converted to degrees Celsius $\left({ }^{\circ} \mathrm{C}\right)$ as follows:

$$
{ }^{\circ} \mathrm{C}=\left({ }^{\circ} \mathrm{F}-32\right) / 1.8 \text {. }
$$




\section{Datum}

Vertical coordinate information is referenced to the North American Vertical Datum of 1988 (NAVD 88).

Horizontal coordinate information is referenced to the North American Datum of 1983 (NAD 83).

\section{Supplemental Information}

Specific conductance is given in microsiemens per centimeter at 25 degrees Celsius $(\mu \mathrm{S} / \mathrm{cm}$ at $\left.25^{\circ} \mathrm{C}\right)$.

Concentrations of chemical constituents in water are given in either milligrams per liter (mg/L) or micrograms per liter $(\mu \mathrm{g} / \mathrm{L})$. One milligram per liter is equivalent to 1 part per million (ppm); 1 microgram per liter is equivalent to 1 part per billion (ppb).

\section{Abbreviations and Acronyms}

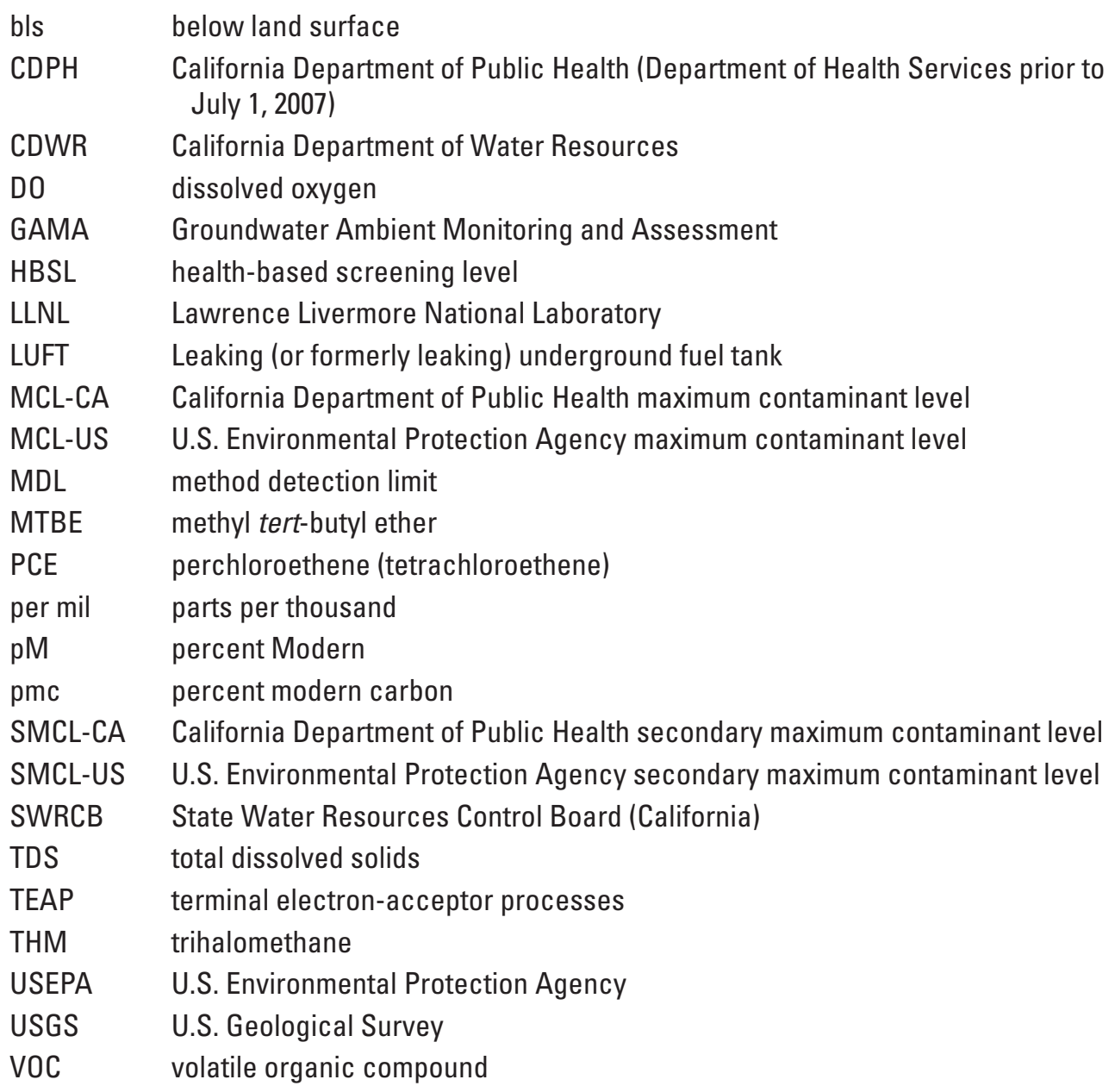




\title{
Status of Groundwater Quality in the Santa Barbara Study Unit, 2011: California GAMA Priority Basin Project
}

\author{
By Tracy A. Davis and Justin T. Kulongoski
}

\section{Abstract}

Groundwater quality in the 48-square-mile Santa Barbara study unit was investigated in 2011 as part of the California State Water Resources Control Board's Groundwater Ambient Monitoring and Assessment (GAMA) Program Priority Basin Project. The study unit is mostly in Santa Barbara County and is in the Transverse and Selected Peninsular Ranges hydrogeologic province. The GAMA Priority Basin Project is carried out by the U.S. Geological Survey in collaboration with the California State Water Resources Control Board and Lawrence Livermore National Laboratory.

The GAMA Priority Basin Project was designed to provide a statistically unbiased, spatially distributed assessment of the quality of untreated groundwater in the primary aquifer system of California. The primary aquifer system is defined as that part of the aquifer corresponding to the perforation interval of wells listed in the California Department of Public Health database for the Santa Barbara study unit. This status assessment is intended to characterize the quality of groundwater resources in the primary aquifer system of the Santa Barbara study unit, not the treated drinking water delivered to consumers by water purveyors.

The status assessment for the Santa Barbara study unit was based on water-quality and ancillary data collected in 2011 by the U.S. Geological Survey from 23 sites and on water-quality data from the California Department of Public Health database for January 24, 2008-January 23, 2011. The data used for the assessment included volatile organic compounds; pesticides; pharmaceutical compounds; two constituents of special interest, perchlorate and $\mathrm{N}$-nitrosodimethylamine (NDMA); and naturally present inorganic constituents, such as major ions and trace elements. Relative-concentrations (sample concentration divided by the health- or aesthetic-based benchmark concentration) were used to evaluate groundwater quality for those constituents that have federal or California regulatory and non-regulatory benchmarks for drinking-water quality. For inorganic, organic, and special-interest constituents, a relative-concentration greater than 1.0 indicates a concentration greater than the benchmark and is classified as high. Inorganic constituents are classified as moderate if relative-concentrations are greater than 0.5 and less than or equal to 1.0 and are classified as low if relative-concentrations are less than or equal to 0.5 . For organic and special-interest constituents, the boundary between moderate and low relative-concentrations was set at 0.1 .

Aquifer-scale proportion was used as the primary metric for evaluating regional-scale groundwater quality. High aquifer-scale proportion is defined as the areal percentage of the primary aquifer system with a relative-concentration greater than 1.0 for a particular constituent or class of constituents. Moderate and low aquifer-scale proportions were defined as the areal percentage of the primary aquifer system that had moderate and low relative-concentrations, respectively. Two statistical approaches - grid based and spatially weighted — were used to calculate aquifer-scale proportions for individual constituents and constituent classes. Grid-based and spatially weighted estimates were comparable in this the study (within 90-percent confidence intervals). Grid-based results were selected for use in the status assessment unless, as was observed in a few cases, a gridbased result was zero and the spatially weighted result was not zero, in which case, the spatially weighted result was used.

Inorganic constituents that have human-health benchmarks were present at high relative-concentrations in 5.3 percent of the primary aquifer system and at moderate concentrations in 32 percent. High aquifer-scale proportions of inorganic constituents primarily were a result of high aquifer-scale proportions of boron (5.3 percent) and fluoride (5.3 percent). Inorganic constituents that have aesthetic-based benchmarks, referred to as secondary maximum contaminant levels, were present at high relative-concentrations in 58 percent of the primary aquifer system and at moderate concentrations in 37 percent. Iron, manganese, sulfate, and total dissolved solids were the inorganic constituents with secondary maximum contaminant levels present at high relative-concentrations. 
In contrast, organic and special-interest constituents that have health-based benchmarks were not detected at high relative-concentrations in the primary aquifer system. Of the 218 organic constituents analyzed, 10 were detected -9 that had human-health benchmarks. Organic constituents were present at moderate relative-concentrations in 11 percent of the primary aquifer system. The moderate aquifer-scale proportions were a result of moderate relative-concentrations of the volatile organic compounds methyl tert-butyl ether (MTBE, 11 percent) and 1,2-dichloroethane (5.6 percent). The volatile organic compounds 1,1,1-trichloroethane, 1,1-dichloroethane, bromodichloromethane, chloroform, MTBE, and perchloroethene (PCE); the pesticide simazine; and the special-interest constituent perchlorate were detected at more than 10 percent of the sites in the Santa Barbara study unit. Perchlorate was present at moderate relativeconcentrations in 50 percent of the primary aquifer system. Pharmaceutical compounds and NDMA were not detected in the Santa Barbara study unit.

\section{Introduction}

To assess the quality of ambient groundwater in aquifers used for drinking-water supply and to establish a baseline for a groundwater-quality monitoring program, the California State Water Resources Control Board (SWRCB), in collaboration with the U.S. Geological Survey (USGS) and Lawrence Livermore National Laboratory (LLNL), implemented the Groundwater Ambient Monitoring and Assessment (GAMA) Program (California State Water Resources Control Board, website accessed May 27, 2014, at http://www.waterboards. ca.gov/gama/). The statewide GAMA Program currently consists of four projects: (1) the GAMA Priority Basin Project of the USGS (U.S. Geological Survey, website accessed May 27, 2014, at http://ca.water.usgs.gov/gama/), (2) the GAMA Domestic Well Project of the SWRCB, (3) the GAMA Special Studies of LLNL, and (4) the GeoTracker GAMA on-line database of the SWRCB. On a statewide basis, the GAMA Priority Basin Project primarily focuses on the deep portion of the groundwater resource (the primary aquifer system), and the SWRCB Domestic Well Project generally focuses on the shallow-aquifer system.

The SWRCB initiated the GAMA Program in response to legislative mandates (State of California, 2001). Following the Groundwater Quality Monitoring Act of 2001, the GAMA Priority Basin Project was initiated to assess and monitor the quality of groundwater in California (State of California, 2001). The GAMA Priority Basin Project is a comprehensive assessment of statewide groundwater quality designed to improve the understanding of, and to identify risks to, groundwater resources and to increase the information about groundwater quality available to the public. The USGS, in collaboration with the SWRCB, developed the GAMA Priority Basin Project, which is a monitoring plan to assess groundwater basins through direct sampling of groundwater and other statistically reliable sampling approaches (Belitz and others, 2003; California State Water Resources Control Board, 2003). Additional partners in the GAMA Priority Basin Project include the California Department of Public Health (CDPH), California Department of Pesticide Regulation (CDPR), California Department of Water Resources (CDWR), and local water agencies and well owners (Kulongoski and Belitz, 2004).

The range of hydrologic, geologic, and climatic conditions that exists in California must be considered in an assessment of groundwater quality. Belitz and others (2003) partitioned the State into 10 hydrogeologic provinces, each having distinct hydrologic, geologic, and climatic characteristics (fig. 1). These hydrogeologic provinces include groundwater basins and subbasins designated by the CDWR (California Department of Water Resources, 2003). Groundwater basins generally consist of relatively permeable, unconsolidated deposits of alluvial origin. Of the approximately 16,000 active and standby public-supply wells listed in the statewide database maintained by the CDPH (CDPH sites), 80 percent are in designated groundwater basins. (The CDPH Drinking Water Program that regulated water quality in public-supply wells was transferred to the SWRCB division of Drinking Water on July 1, 2014; however, the label "CDPH" is retained in this report for consistency with other GAMA Priority Basin Project publications and because the CDPH had jurisdiction over public-supply wells when samples were collected for this study.) Groundwater basins and subbasins were prioritized for sampling on the basis of the number of CDPH sites in the basin; secondary consideration was given to municipal groundwater use, agricultural pumping, the number of historically leaking underground fuel tanks, and registered pesticide applications (Belitz and others, 2003). Of the 472 basins and subbasins designated by the CDWR, 116 were designated as priority basins because they contained approximately 95 percent of the CDPH sites in basins. The remaining 356 basins were defined as low-use basins. The priority basins, selected low-use basins, and selected areas outside defined groundwater basins were grouped into 35 GAMA Priority Basin Project study units. The Santa Barbara study unit is the 34th study unit and is in the western part of the Transverse and Selected Peninsular Ranges hydrogeologic province (fig. 1).

The goal of the GAMA Priority Basin Project is to produce three types of water-quality assessments for each study unit: (1) Status, the assessment of the current quality of the groundwater resource; (2) Understanding, the identification of the natural and human factors affecting groundwater quality and explanation of the relations between water quality and selected explanatory factors; and (3) Trends, the detection of changes in groundwater quality over time (Kulongoski and Belitz, 2004). The assessments are intended to characterize the quality of groundwater in the primary aquifer system of the study unit, not the treated drinking water delivered to consumers by water purveyors. 


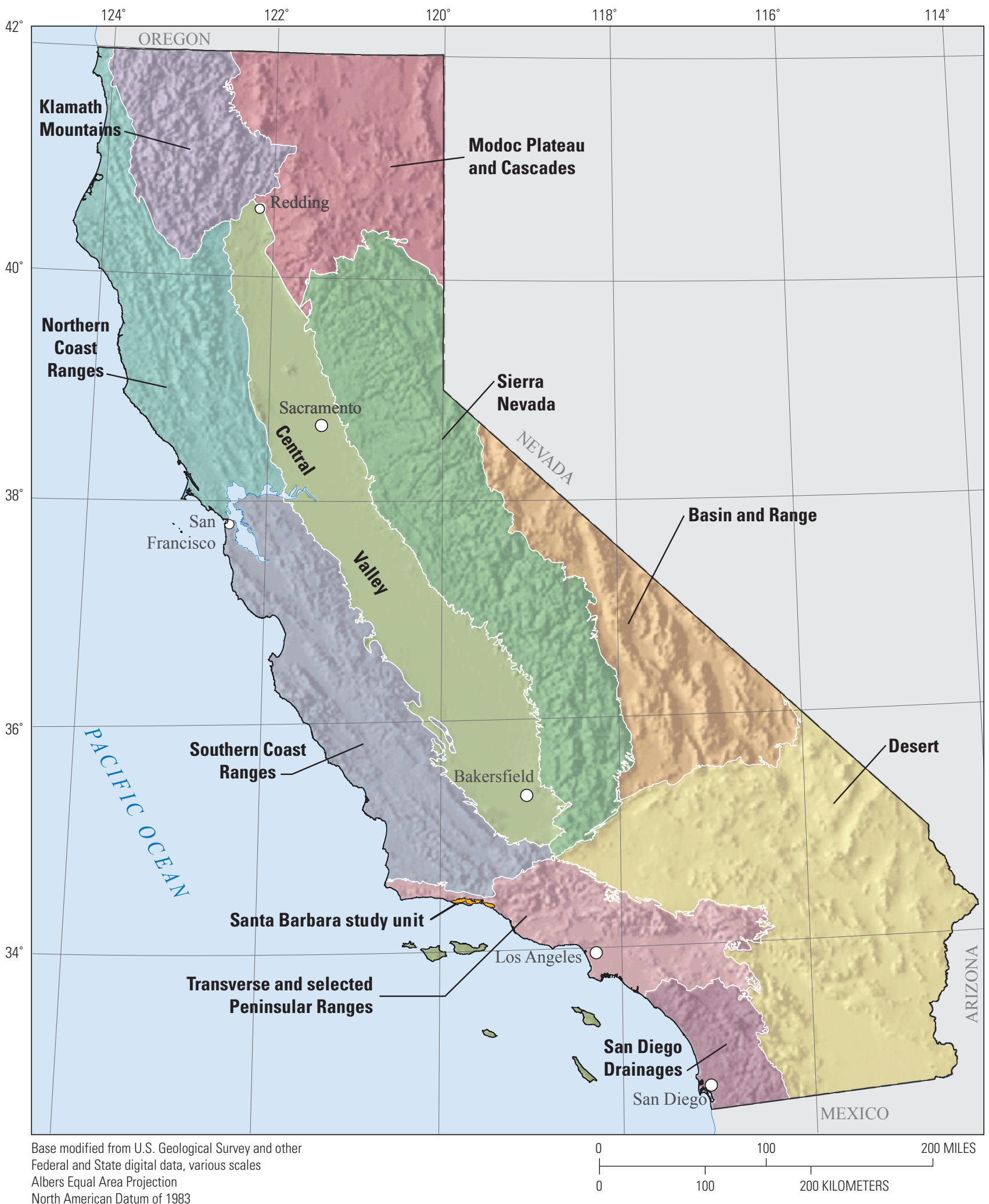

Figure 1. The hydrogeologic provinces of California and the location of the Santa Barbara study unit, 2011, California Groundwater Ambient Monitoring and Assessment (GAMA) Priority Basin Project. 
The primary aquifer system for a study unit is defined by the depths of the screened or open intervals of the sites listed in the CDPH water-quality database for the study unit. The CDPH water-quality database lists wells and springs used for public drinking-water supplies and includes wells and springs from systems classified as community (such as those in cities, towns, and mobile-home parks); non-transient, non-community (such as those in schools, workplaces, and restaurants); and transient, non-community (such as those in campground, and parks). Groundwater quality in the primary aquifer system can differ from that in shallower or deeper parts of the aquifer system. In particular, shallower groundwater could be more vulnerable to contamination from activities at, or near, the land surface.

\section{Purpose and Scope}

The purposes of this report are to provide (1) a study unit description, which is a description of the hydrogeologic setting of the Santa Barbara study unit; (2) a status assessment, which is an assessment of the status of the current quality of groundwater in the primary aquifer system in the study unit; and (3) a compilation of ancillary data, which is a compilation of data for selected factors that can be useful for explaining water quality. This report describes methods used to design the sampling network, to identify CDPH data for use in the status assessment, to estimate aquifer-scale proportions of relative-concentrations, to compile ancillary datasets, to classify groundwater age, and to assess the status of groundwater quality by statistical and graphical approaches. Water-quality data for samples collected by the USGS for the GAMA Program in the Santa Barbara study unit and details of sample collection, analysis, and quality-assurance procedures are reported by Davis and others (2013). The understanding assessment and trends are not discussed in this report.

The status assessment includes analyses of waterquality data for 18 sites selected by the USGS for spatial coverage of 1 well per grid cell (USGS grid sites) in the Santa Barbara study unit. Samples were collected for analysis of anthropogenic constituents, such as VOCs and pesticides, and naturally present inorganic constituents, such as major ions and trace elements. Water-quality data from the CDPH database were used to supplement data collected by the USGS for the GAMA Priority Basin Project. The resulting set of water-quality data from the USGS grid sites and selected $\mathrm{CDPH}$ sites was considered to be representative of the primary aquifer system in the study unit. GAMA status assessments were designed to provide a statistically robust characterization of groundwater quality in the primary aquifer system at the basin scale (Belitz and others, 2003), which allows results to be synthesized regionally and statewide.

To provide context, the water-quality data discussed in this report were compared to California and federal drinking-water regulatory and non-regulatory benchmarks for treated drinking water. The assessments in this report characterize the quality of untreated groundwater resources in the primary aquifer system in the study unit, not the drinking water delivered to consumers by water purveyors. After withdrawal from the ground, water typically is treated, disinfected, or blended with other water to attain acceptable water quality. Regulatory benchmarks apply to treated water that is served to the consumer, not to untreated groundwater.

Ancillary datasets include potential explanatory factors that can be useful for explaining water quality. The potential explanatory factors include hydrologic conditions, land use, distance to leaking underground fuel tanks (LUFTs), septic tank density, well depth and depth to top-ofperforations, groundwater age, and geochemical conditions. This report discusses the methods used to attribute sites with characteristics that could be used in an assessment of understanding in future reports. In addition to the 18 USGS grid sites sampled for the status assessment, 6 additional sites were sampled by the USGS (USGS understanding sites) to help explain the natural and human factors affecting groundwater quality.

\section{Hydrogeologic Setting of the Santa Barbara Study Unit}

As part of the GAMA Priority Basin Project, untreated groundwater samples were collected from 24 sites (18 grid sites, 5 understanding sites, and 1 additional understanding site not included in this status assessment) in the Santa Barbara study unit from January 24, 2011, to February 16, 2011 (Davis and others, 2013). The Santa Barbara study unit is in the Transverse and Selected Peninsular Ranges hydrogeologic province described by Belitz and others (2003; fig. 1). The study area is approximately 48-square miles $\left(\mathrm{mi}^{2}\right)$ and is primarily in Santa Barbara County, but it extends east into Ventura County. From west to east, the study unit includes five CDWR-defined groundwater basins: Goleta, Foothill, Santa Barbara, Montecito, and Carpinteria (fig. 2; California Department of Water Resources, 2003). Land use in the study unit is predominantly urban intermixed with small areas of natural land. Agricultural land use primarily is found in the eastern region and along the outskirts of the western region of the study unit. Climate in the Santa Barbara study unit is characterized as Mediterranean, with warm, dry summers and cool, moist winters. Average annual temperature in the study unit is 60 degrees Fahrenheit $\left({ }^{\circ} \mathrm{F}\right)$, or 15.5 degrees Celsius $\left({ }^{\circ} \mathrm{C}\right)$, and the average annual precipitation is about 17 inches, which falls as rain mostly during the winter and early spring (National Climatic Data Center, National Oceanic and Atmospheric Administration home page, accessed October 27, 2011, at http://www.ncdc.noaa.gov/cdo-web/ search? datasetid=ANNUAL). 


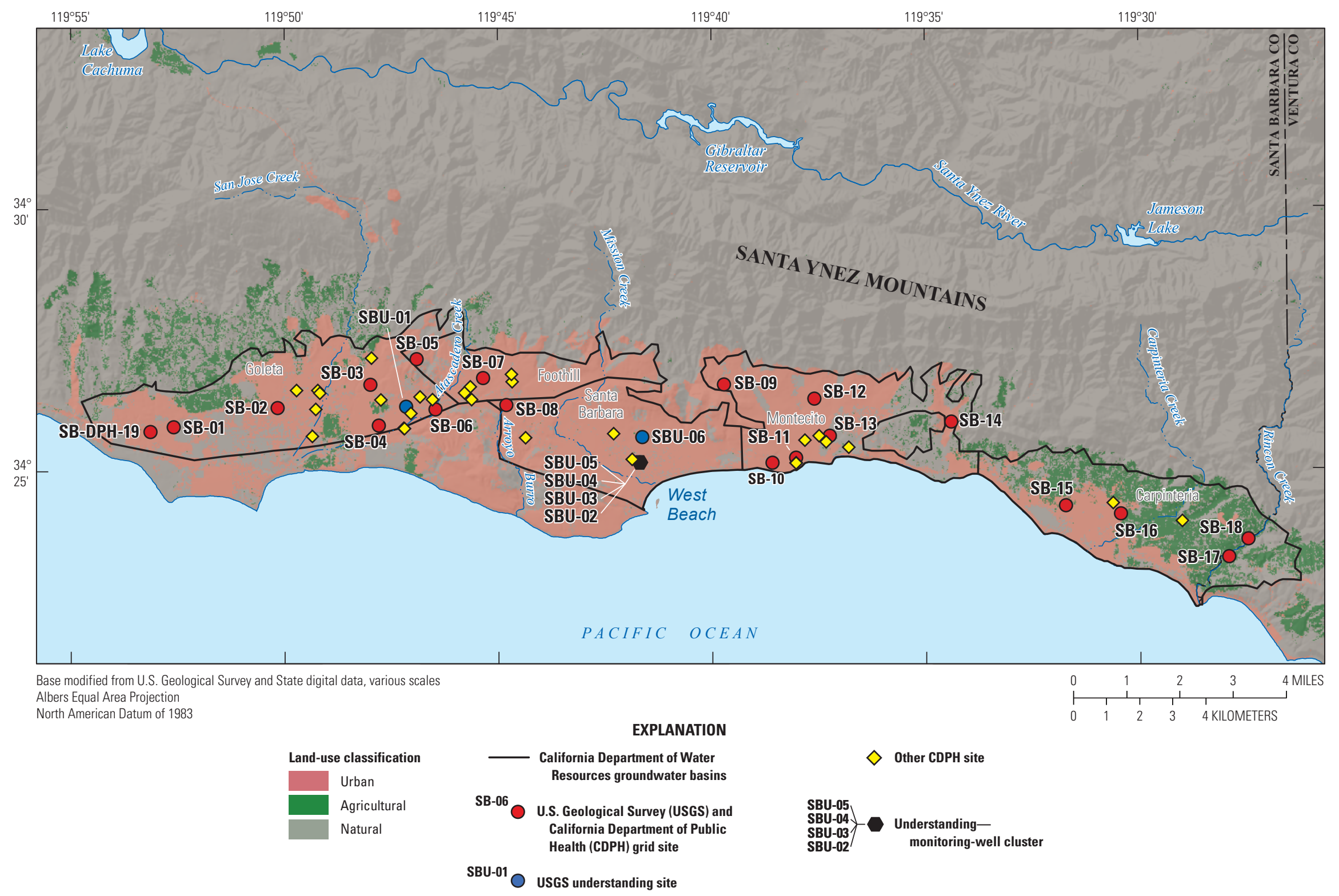

Figure 2. Land use, California Department of Water Resources (CDWR)-defined groundwater basins, and locations and identifiers for U.S. Geological Survey (USGS) grid, California Department of Public Health (CDPH) grid, and USGS understanding sites, Santa Barbara study unit, 2011, California Groundwater Ambient Monitoring and Assessment (GAMA) Priority Basin Project. 
The study unit is on a narrow coastal strip of land, known as the Santa Barbara Coastal Plain, bounded by the Santa Ynez Mountains in the north and the Pacific Ocean in the south. The primary aquifer system in the study unit is composed of the mostly unconsolidated Quaternary Santa Barbara and Casitas Formations as well as younger and older alluvial deposits (fig. 3; California Department of Water Resources, 2004a-e; Minor and others, 2009). The Santa Barbara Formation is the major water-bearing unit for the Goleta, Foothill, and Santa Barbara Basins and, to a lesser extent, for the Montecito and Carpinteria Basins. The formation consists of fine- to mediumgrained marine sandstone of middle and lower Pleistocene age. The Casitas Formation, which is the major water-bearing unit for Montecito and Carpinteria Basins, consists of nonmarine deposits of upper and middle Pleistocene age. Santa Barbara and Casitas Formations are overlain with older alluvial and terrace deposits, which are composed of clay, sand, silt, and gravel. Pleistocene marine-terrace deposits possibly underlie older alluvial deposits in the Goleta Valley and surface at the sea cliffs elevated along the More Ranch Fault (Minor and others, 2009). Holocene alluvium primarily composes the urban or agricultural plains of Goleta, Santa Barbara, and Carpinteria and extends along stream channels and adjoining canyons throughout the study unit (Freckleton and others, 1998). Marine sediments of the Tertiary age form the bedrock for the groundwater basins and compose the surrounding foothills of the Santa Ynez Mountains. These consolidated rocks are semi water-bearing where extensively fractured. The primary aquifer system targeted by this study includes groundwater-bearing zones in which active public supply wells (CDPH database) are completed. These wells vary in depth from 150 to $1,245 \mathrm{ft}$ below land surface datum (LSD).

Faults are abundant throughout the study unit and define some groundwater basin boundaries because they impede water flow in, and along the perimeter of, the Santa Barbara study unit. The individual faults are part of the larger Santa Barbara fold and fault belt along the Santa Ynez Mountains (Minor and others, 2009). The east-west trending Santa Barbara fold and fault belt contains three major fault systems: the west-northwest-trending Mission Ridge fault zone and Arroyo Parida fault and the east-northeast-trending More Ranch fault (fig. 3). Along the southern boundary of the study unit, saltwater intrusion is partially restricted by uplift along the More Ranch fault in the southwest, the Mesa and Lavigia faults in the central part of the coastal plain, and the Rincon Creek fault in the southeast (California Department of Water Resources, 2004a-e). The deeper water-bearing deposits in the Santa Barbara groundwater basin were thought to be protected from saltwater intrusion by a barrier created by an offshore fault. Results of a study, however, found elevated chloride concentrations in the deep zones of the aquifer following a decline in groundwater levels to below sea level during 1978-80, which indicated ocean water had intruded these deeper water-bearing zones (Martin, 1984). Following this study, groundwater pumping was greatly reduced, and waterlevels have been increasing or relatively stable in the Santa Barbara primary aquifer system (County of Santa Barbara, 2011, Groundwater Report, accessed July 30, 2014 at http://cosb.countyofsb.org/pwd/pwwater.aspx?id=41398).

The sources of surface discharge for the study unit are several creeks that flow from the mountains to the Pacific Ocean. The study unit is drained primarily by Mission Creek and its tributaries (fig. 3). The creek originates in the Santa Ynez Mountains and flows southeast to the Pacific Ocean, just east of West Beach (Izbicki and others, 2009). Other surfacedrainage features include San Jose, Atascadero, Arroyo Burro, Carpinteria, and Rincon Creeks. The primary sources of discharge in the groundwater basins are water pumped for municipal supply and subsurface outflow to other basins. Sources of recharge in the groundwater basins are infiltration of precipitation and irrigation water, seepage from creeks and streams, diversions from Lake Cachuma and Gibraltar Reservoir to Mission Creek, and subsurface inflow from consolidated rocks of the Santa Ynez Mountains (California Department of Water Resources, 2004a-e).

Water resources for Santa Barbara's public water supply are local reservoirs, including Lake Cachuma and Gibraltar Reservoir; water imported from the State Water Project; groundwater; and recycled water, which is used only for irrigation only (California Department of Water Resources, 2004a-e; City of Santa Barbara, 2014). In an effort to offset declining water supplies in Santa Barbara caused by the current drought conditions in California, the city of Santa Barbara is in the process of reactivating the desalination facility, which has been on standby since 1992 (City of Santa Barbara, 2014). 


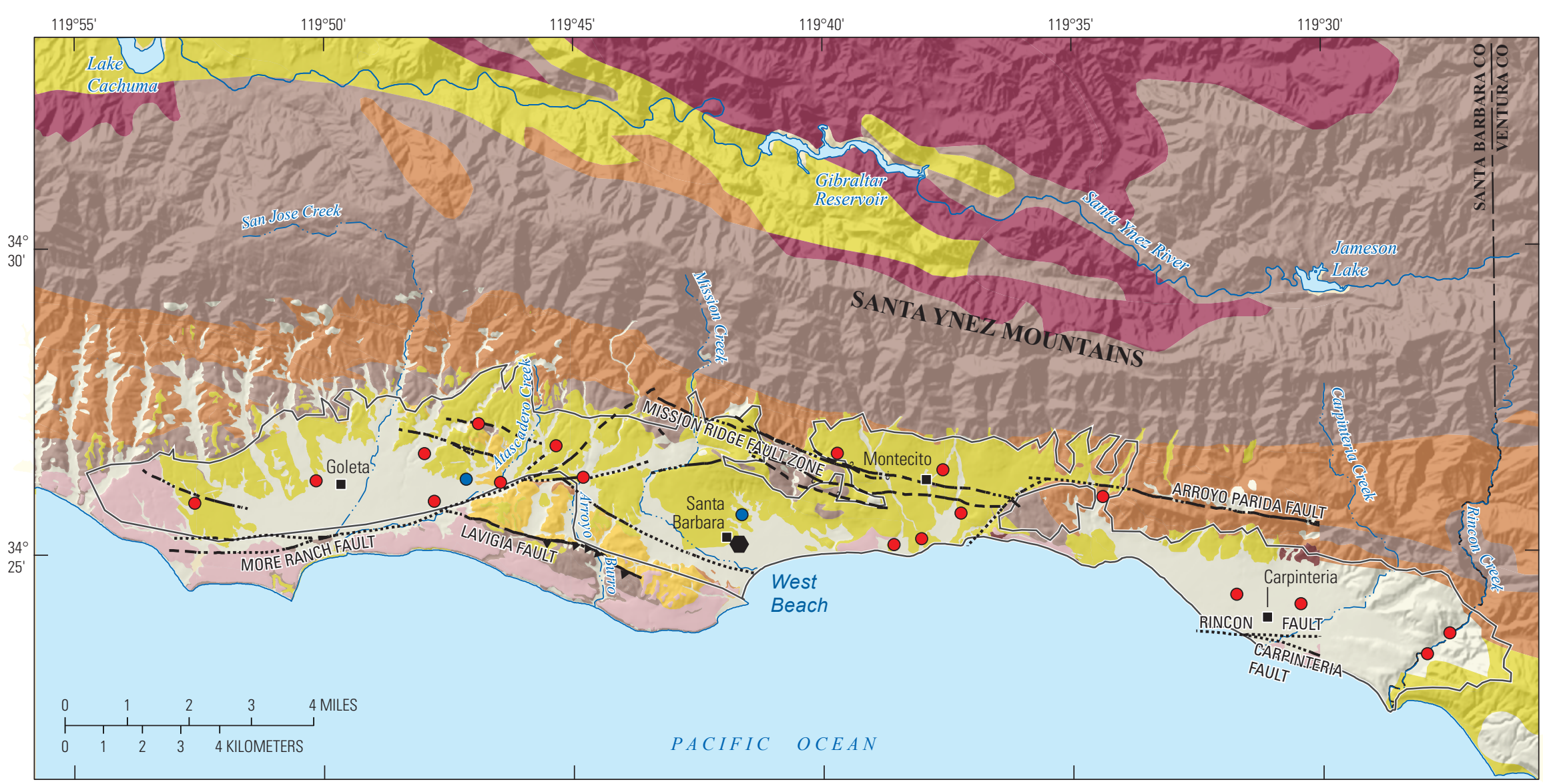

Base modified from U.S. Geological Survey and State digital data, various scales Albers Equal Area Projection

Geology modified from Saucedo and others (2000) North American Datum of 1983

\section{EXPLANATION}

\section{Geologic description}

19. Older alluvial deposits (Pleistocene)

(1) Santa Barbara Formation (Pleistocene)

Casitas Formation (Pleistocene)

Alluvial and surficial deposits (Holocene and upper Pleistocene)
13. Marine-terrace deposits (upper Pleistocene)

Marine mudstone and shale

$$
\text { (Miocene and some Pliocene) }
$$

39) Sandstone and mudstone in the shallower unit, with conglomerates in the lower unit (Oligocene) Metamorphic marine sediment (Mesozoic)

\section{— Study unit boundary}

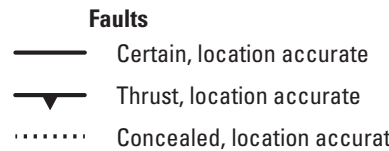

....... Concealed, location accurate

Figure 3. Santa Barbara study unit, 2011, California Groundwater Ambient Monitoring and Assessment (GAMA) Priority Basin Project.

Geology modified from Saucedo
and Minor and others (2009).

U.S. Geological Survey site and identifier SB-06

$\begin{array}{lll}\text { SBU-01 } & \text { Understanding } \\ \text { SBU-05 } & \text { Understanding- } \\ \text { SBU-04 } \\ \text { SBU-03 } \\ \text { SBU-02 }\end{array}$




\section{Methods}

The status assessment provides a spatially unbiased assessment of groundwater quality in the primary aquifer system of the Santa Barbara study unit. This section describes the methods used for (1) defining groundwater quality, (2) assembling the datasets used for the assessment, (3) determining which constituents warrant additional evaluation, and (4) calculating aquifer-scale proportions.

The primary metric for defining groundwater quality is relative-concentration, which refers to the concentrations of constituents measured in groundwater relative to regulatory and non-regulatory benchmarks used to evaluate drinking-water quality. Constituents were selected for additional evaluation in the status assessment on the basis of objective criteria that are based on relative-concentrations. Groundwater-quality data collected by the U.S. Geological Survey for the GAMA Priority Basin Project (USGS-GAMA) and data compiled in the CDPH database are used in the status assessment. Two statistical approaches based on spatially unbiased equal-area grids are used to calculate aquifer-scale proportions of low, moderate, or high relative-concentrations (Belitz and others, 2010): (1) the "grid-based" approach uses one value per grid cell to represent groundwater quality, and (2) the "spatially weighted" approach uses many values per grid cell.

The CDPH database contains historical records from more than 25,000 sites, necessitating targeted retrievals to effectively access relevant water-quality data. For example, for the area representing the Santa Barbara study unit, the CDPH database contains more than 2,035 records from 72 sites (excluding destroyed sites). The CDPH data were used in three ways in the status assessment: (1) to fill in gaps in the USGS data for the grid-based calculations of aquiferscale proportions, (2) to aid the selection of constituents for additional evaluation in the assessment, and (3) to supplement the data used in the spatially weighted calculations of aquiferscale proportions.

\section{Water-Quality Benchmarks and Relative- Concentrations}

To provide context for the water-quality data, measured concentrations of constituents can be compared to waterquality benchmarks established by the U.S. Environmental Protection Agency (USEPA) and CDPH (U.S. Environmental Protection Agency, 1999, 2013, 2016; California State Water Resources Control Board, 2016a, 2016b). The benchmarks used for each constituent were selected in the following order of priority:

- Regulatory, health-based CDPH and USEPA maximum contaminant levels (MCL-CA and MCL-US); action levels (AL-US); and treatment technique levels (TTUS).

- Non-regulatory, non-health based CDPH and USEPA secondary maximum contaminant levels (SMCL-CA and SMCL-US). For constituents both with recommended and upper SMCL-CA levels, the values for the upper levels were used.

- Non-regulatory, health-based CDPH notification levels (NL-CA); USEPA lifetime health advisory levels (HAL-US); and USEPA risk-specific doses for 1:100,000 (RSD5-US).

For constituents with multiple types of benchmarks, this hierarchy might not result in selection of the benchmark with the lowest concentration. Additional information about the types of benchmarks and the listings of the benchmarks for all constituents analyzed are provided by Davis and others (2013).

Concentrations of constituents are presented as relativeconcentrations, which are the concentrations of constituents measured in groundwater relative to regulatory and nonregulatory benchmarks used to evaluate drinking-water quality, calculated as follows:

\section{Relative-concentration $=\frac{\text { Sample concentration }}{\text { Benchmark concentration }}$}

Relative-concentrations were used to provide context for the measured concentrations in the sample. Relativeconcentrations less than or equal to 1.0 indicate a sample concentration less than or equal to the benchmark, and relative-concentrations greater than 1.0 indicate a sample concentration greater than the benchmark. The use of relativeconcentrations also permits comparison of constituents present at a wide range of concentrations on a single scale. Relativeconcentrations can only be computed for constituents with water-quality benchmarks; constituents without water-quality benchmarks are not included in the status assessment.

Previously, Toccalino and others (2004), Toccalino and Norman (2006), and Rowe and others (2007) used the ratio of measured sample concentration to the benchmark concentration - either the MCL-US or the health-based screening level (HBSL) - and defined this ratio as the "benchmark quotient." HBSLs were not used in this report because HBSLs are not currently used as benchmarks by California drinking-water regulatory agencies. Because different water-quality benchmarks are used to calculate relative-concentrations and benchmark quotients, the terms are not interchangeable.

For ease of discussion, relative-concentrations of constituents were classified into low, moderate, and high categories, as shown in table 1. 
For organic and special-interest constituents, a relativeconcentration of 0.1 was used as the threshold to distinguish between low and moderate relative-concentrations to be consistent with other studies and reporting requirements (U.S. Environmental Protection Agency, 2009; Toccalino and others, 2004). For inorganic constituents, a relativeconcentration of 0.5 was used as the threshold to distinguish between low and moderate relative-concentrations. The inorganic constituents naturally present in groundwater tend to be more common than organic constituents in groundwater. The higher threshold was used to focus attention on the inorganic constituents of greater concern (Fram and Belitz, 2012). Although more complex classifications based on the properties and sources of individual constituents could be devised, the use of a single moderate/low threshold value for each of the two major groups of constituents provided consistent objective criteria for distinguishing constituents present at moderate, rather than low, concentrations.

\section{Datasets for Status Assessment}

Groundwater-quality data collected by the USGS for the GAMA Priority Basin Project (USGS-GAMA) and data compiled from the CDPH database were used in the status assessment. Two datasets were constructed, one for each method used to calculate aquifer-scale proportions: grid-based and spatially weighted.

\section{Data for Grid-Based Calculations of Aquifer- Scale Proportions}

The primary data used for grid-based calculations of aquifer-scale proportions of relative-concentrations were data from sites sampled by USGS-GAMA. Detailed descriptions of the methods used to identify sites for sampling are given by Davis and others (2013). The Santa Barbara study unit was divided into 20 equal-area grid cells, each cell was approximately $2.4 \mathrm{mi}^{2}$ in area, and one randomly selected well in each cell was sampled (Scott, 1990). The USGS sampled wells in 18 of the 20 grid cells (USGS grid sites). Of the 18 USGS grid sites, 11 were listed in the CDPH database, and the other 7 sites ( 2 domestic sites and 5 irrigation sites) were screened or perforated at depth intervals similar to those of sites listed in the CDPH database. The USGS grid sites were named with an alphanumeric GAMA site identifier consisting of a prefix identifying the study unit (SB), followed by a number indicating the relative location of the site within the study unit, from west to east (see appendix 1 for locations and identifiers of grid sites in the Santa Barbara study unit).

Samples were collected from all USGS-GAMA sites for analysis of organic constituents (VOCs, pesticides, and pharmaceuticals), constituents of special interest (perchlorate and $N$-nitrosodimethylamine), inorganic constituents (trace elements, major ions, and nutrients), radioactive constituents (gross alpha and gross beta particle activities and radon-222), and geochemical and age-dating tracers (field water-quality parameters, noble gases, tritium, stable isotopes of water, carbon isotopes, and redox species; table 2). Samples collected by USGS-GAMA provided all of the data for the USGS grid sites used in the grid-based status assessment. Water-quality data collected by USGS-GAMA were tabulated by Davis and others (2013) and also are available from the SWRCB's publically accessible internet database GeoTracker GAMA (website at http://www.waterboards.ca.gov/gama/geotracker_ gama.shtml).

Results for trihalomethanes from one USGS grid-site sample were not included in this status assessment. One trihalomethane - chloroform - was detected in a sample from SB-04 at a concentration of $21.8 \mu \mathrm{g} / \mathrm{L}$. This detection was the only moderate relative-concentration of chloroform in groundwater samples from USGS grid, USGS understanding, or $\mathrm{CDPH}$ sites during the period of study. Investigation of field notes indicated that this site is chlorinated at a point in the well system upstream from where samples were collected. Although the chlorinator was shut off prior to purging and sampling of the site, it is likely that detections of chlorination by-products, such as trihalomethanes, are at least in part attributable to residual chlorine. The purpose of this study is to assess untreated-groundwater quality in the primary aquifer system; therefore, results for trihalomethanes at this site were omitted from the datasets for the status assessment, including the dataset used for the spatially weighted calculations discussed in the next section. The nine other USGS grid and USGS understanding sites where there were detections of trihalomethanes in the samples were sites that had chlorination points downstream from the sample collection point or were sites that had no reported well treatment.

The CDPH database was queried to provide data for the cells without USGS-GAMA data. The CDPH sites that had data for the most recent 3 years available at the time of sampling (January 24, 2008-January 23, 2011) were considered. If a site had more than one analysis for a constituent in the 3-year interval, then the most recent result was selected. The procedures used to identify suitable data from CDPH sites are described in appendix 1. One well (CDPH grid site) was selected from the CDPH database to provide data for one of the two cells without USGS grid sites. The CDPH grid site was named with the prefix "SB-DPH," followed by the next number in the sequence of grid sites (19, see table 1-1). This site did not have data for all missing inorganic constituents; therefore, the number of sites used for the grid-based assessment differed for various inorganic constituents. No accessible sites or data were available for the remaining cell.

The CDPH data were not used to provide grid values for VOCs, pesticides, or perchlorate for the status assessment because a greater number of VOCs and pesticide compounds are analyzed for the USGS-GAMA program than are available from the CDPH database. In addition, method detection limits for USGS-GAMA analyses were typically one to two orders of magnitude less than the reporting levels for analyses compiled by the CDPH (table 3 ). 


\section{Data for Spatially Weighted Calculations of Aquifer-Scale Proportions}

The spatially weighted aquifer-scale proportions were calculated by using data from USGS grid sites, data from all sites in the CDPH database that had water-quality data from the 3-year interval during January 24, 2008-January 23, 2011, and data from five USGS understanding sites that were perforated at depth intervals similar to sites in the CDPH database. The USGS understanding sites sampled by the USGS (fig. 2) to further investigate specific groundwaterquality issues in the Santa Barbara study unit were named by using the prefix SBU, followed by a number indicating the relative location of the site within the study unit (from west to east) or, for the monitoring-well cluster (SBU-03-SBU-05), well depth (from deep to shallow). The USGS understanding sites provide additional information about factors potentially affecting water quality in the primary aquifer system, such as saltwater intrusion and redox conditions. For sites that both had USGS-GAMA and CDPH data, only the USGS-GAMA data were used. Water-quality data collected by the CDPH are available from the SWRCB's publically accessible internet database GeoTracker GAMA (http://www.waterboards.ca.gov/ gama/geotracker_gama.shtml).

An additional USGS understanding site (SBU-02) was sampled by USGS-GAMA; however, results from this site were not considered to be representative of the primary aquifer system and were not included in the dataset for the spatially weighted calculations. SBU-02 is one of five wells in a monitoring-well cluster and represents the "deep zone" of the Santa Barbara groundwater basin (Martin, 1984). Historical data have indicated that the deep zone produces groundwater with high concentrations of salinity indicators, which is likely confined to this deep zone. The deep zone is monitored as a possible source of high salinity for other wells in the basin. Only one well sampled in 1979 in the Santa Barbara groundwater basin had major ion results indicative of mixing with the deep zone. Production wells in this area are generally screened at intervals shallower than the deep zone. Results for SBU-02 were not included in the status assessment or in the summaries of potential explanatory factors, but were included in the appendix tables as reference for further salinity discussion in the results section, "Chloride, Sulfate, and Total Dissolved Solids." During this assessment, it also was determined that the groundwater-age classifications for samples taken from the deep zone (SBU-02) and the upper producing zone (SBU-05) were likely to have been erroneous, possibly the result of a sample mix-up. The age classifications and carbon isotope results for these samples were rejected and omitted from this report pending re-sampling of the sites.

Another result rejected from this status assessment was an arsenic concentration $(17.6 \mu \mathrm{g} / \mathrm{L})$ greater than the MCL-US $(10 \mu \mathrm{g} / \mathrm{L})$ in a sample from one CDPH site in the Santa Barbara study unit during the 3-year study period. Eighteen other arsenic results in the CDPH database collected at this site between 1990 and 2011 ranged from non-detections to $1.3 \mu \mathrm{g} / \mathrm{L}$. Arsenic was not detected at high relative-concentrations in samples from any other CDPH site during the study period, and it was detected only at low concentrations in samples from the USGS-GAMA sites. The high arsenic result was omitted from the dataset for spatially weighted calculations.

\section{Selection of Constituents for Additional Evaluation}

As many as 284 constituents were analyzed in USGSGAMA samples for the Santa Barbara study unit, 135 of which had regulatory or non-regulatory benchmarks (table 4). Only a subset of the constituents that had benchmarks were selected for additional evaluation in this report on the basis of the following criteria:

- Constituents present at high or moderate relative-concentrations in samples from USGS grid sites.

- Organic constituents at any concentration detected at frequencies greater than 10 percent in samples from USGS grid sites.

- Constituents present at high or moderate relativeconcentrations in the CDPH database sampled during the 3-year interval January 24, 2008-January 23, 2011, referred to as the study sampling period in this report.

These criteria identified 10 inorganics, 8 organics, and 1 constituent of special interest for additional evaluation in the status assessment. A complete list of the constituents investigated by USGS-GAMA in the Santa Barbara study unit and descriptions of detection and reporting levels is in the Santa Barbara Data Series Report (Davis and others, 2013).

The CDPH database was used to identify constituents that have been reported at high relative-concentrations historically. The historical period was defined as the period starting with the earliest record maintained in the $\mathrm{CDPH}$ electronic database and ending just prior to the period used for the status assessment (March 23, 1984, through January 23, 2008). Constituent concentrations can be historically high, but not high during the study period, because of improvement of the groundwater quality over time or the abandonment of sites where concentrations of constituents in groundwater were high. Historically high concentrations of constituents that do not otherwise meet the criteria for additional evaluation in the status assessment (for example, were not detected at high concentrations during the study period) were not considered representative of potential groundwater-quality concerns in the study unit. The Santa Barbara study unit had 16 historically high constituents (table 5). Six constituents were identified at historically high concentrations, but were not selected for additional evaluation on the basis of data from the study period: aluminum, arsenic, barium, lead, nitrite (as nitrogen), and uranium. Most of these constituents were detected at high concentrations in samples from only one site each. 


\section{Calculation of Aquifer-Scale Proportions}

Estimations of aquifer-scale proportions, based on a spatially distributed grid-cell network across the Santa Barbara study unit, are intended to characterize the water quality of the primary aquifer system. Two statistical approaches, grid-based and spatially weighted, were used to evaluate the areal proportions of the primary aquifer system in the study unit with high, moderate, and low relative-concentrations of constituents (Belitz and others, 2010). For ease of discussion, these proportions are referred to as "high," "moderate," and "low" aquifer-scale proportions. Calculations of aquifer-scale proportions were made for individual constituents meeting the criteria for additional evaluation in the status assessment, as well as for classes of constituents.

The grid-based approach used the dataset assembled from the USGS grid sites and CDPH grid site, where one value from a randomly selected grid site in each grid cell represents the primary aquifer system (Belitz and others, 2010). For organic constituents, the value in each grid cell was obtained from USGS-GAMA results for the 18 grid sites. For inorganic constituents, the value in each grid cell was obtained from USGS-GAMA results for the grid sites and from data in the CDPH database in one additional grid cell not sampled by USGS-GAMA (table 1-1). For each constituent, the grid-based high aquifer-scale proportion was calculated by dividing the number of cells represented by a high relative-concentration (relative-concentration greater than 1) for that constituent by the total number of grid cells that had data for that constituent. Moderate and low aquiferscale proportions were calculated similarly. The proportions for the high, moderate, and low categories were expected to total 100 percent, except for small differences resulting from rounding. Confidence intervals for the grid-based high aquiferscale proportions were computed by using the Jeffreys interval for the binomial distribution (Brown and others, 2001). For calculation of high aquifer-scale proportion for a class of constituents, cells were considered high if any constituent in that particular class had a high relative-concentration. Cells were considered moderate if any constituent in that class had moderate relative-concentration, but none had a high relativeconcentration. The grid-based estimate is spatially unbiased; however, the approach might not identify constituents that are present at high concentration in small proportions of the primary aquifer system.

The spatially weighted approach used data from samples collected during January 24, 2011-February 16, 2011, from the USGS grid sites and five of the USGS understanding sites and from data compiled in the CDPH database for samples collected during January 24, 2008-January 23, 2011. The most recent analysis was used for each constituent at each site. For each constituent, the spatially weighted high aquifer-scale proportion was calculated by computing the proportion of sites where there were high relative-concentrations in each cell and then averaging the proportions for all cells (Isaaks and Srivastava, 1989; Belitz and others, 2010):

$$
P s u=\frac{\sum \frac{\text { Whigh }}{\text { Wtotal }}}{C}
$$

where

$$
\begin{gathered}
\text { Psu is the aquifer-scale proportion for the study } \\
\text { unit, } \\
\text { is the number of cells that have data for the } \\
\text { constituent, }
\end{gathered}
$$

The moderate and low aquifer-scale proportions were calculated similarly. The resulting proportions are spatially unbiased. Raw detection frequencies of high and moderate values were calculated for each constituent by using the same dataset as was used for the spatially weighted calculations. These detection frequencies are not spatially unbiased, because the sites in the CDPH database are not uniformly distributed throughout the Santa Barbara study unit. Detection frequencies are provided for reference and were not used to assess aquifer-scale proportions.

The grid-based high aquifer-scale proportions were used to represent proportions in the primary aquifer system, unless the spatially weighted proportions were significantly different than the grid-based values. Significantly different results were defined as follows:

- If the grid-based high aquifer-scale proportion was zero, and the spatially weighted proportion was nonzero, then the spatially weighted result was used. This can happen when the concentration of a constituent is high in a small fraction of the primary aquifer system.

- If the grid-based high aquifer-scale proportion was non-zero, and the spatially weighted proportion was outside the 90-percent confidence interval (based on the Jeffreys interval for the binomial distribution), then the spatially weighted proportion was used.

The grid-based moderate and low proportions were used in most cases, because the reporting levels for many organic constituents and some inorganic constituents in the $\mathrm{CDPH}$ database were greater than the threshold between moderate and low categories. If the grid-based moderate proportion was zero, however, and the spatially weighted proportion was a non-zero, then the spatially weighted value was used as a minimum estimate for the moderate proportion. 


\section{Potential Explanatory Factors}

The Santa Barbara study unit contains a range of geologic, hydrologic, and land-use settings. Ancillary data for some potential explanatory factors were compiled: hydrologic conditions, land use, densities of leaking (or formerly leaking) underground fuel tanks and septic systems, well construction, geochemical conditions, and groundwater age. Methods used to assign values for each of potential explanatory factors to sites in the Santa Barbara study unit are described in appendix 2 .

\section{Hydrologic Conditions}

The aridity index calculated at the USGS grid and USGS understanding sites in the study unit ranged from 0.29 to 0.38 (dimensionless), and the median value for grid sites was 0.32 (appendix 2; table 2-1; United Nations Educational, Scientific, and Cultural Organization, 1979; Fram and Belitz, 2011). Greater values indicate wetter conditions. All Santa Barbara study unit sites were in the semi-arid range.

\section{Land Use}

Land use was described by three land-use types: natural, urban, and agricultural (appendix 2). Land-use percentages were calculated for the study unit and within a radius of $500 \mathrm{~m}$ (500-m buffers, 1,640-ft) around sites (Johnson and Belitz, 2009). Urban land use was predominant across the study unit, intermixed with small areas of natural land, and agricultural land use was primarily found in the eastern region and along the outskirts of the western region of the study unit (fig. 2).

Agricultural land use in the Santa Barbara study unit consists mainly of orchards or vineyards, row crops, and pasture or hay. Natural lands in the Santa Barbara study unit are shrub lands and grasslands, with lesser amounts of bare rock or sand, open water, mixed and evergreen forests, and wetlands. Land use in the Santa Barbara study unit is 64 percent urban, 23.8 percent natural, and 12.2 percent agricultural based on classifications from the USGS National Land Cover Data (Nakagaki and others, 2007). Compared to the land use in the entire study unit, the average land use in 500-m buffer areas around the USGS grid sites was less natural (20 percent), less agricultural ( 9 percent), and more urban (71 percent). The difference between overall land use in the Santa Barbara study unit and land use around USGS grid sites reflects the fact that wells are preferentially located where there are people living and working. Figure 4 shows the percentage of land use calculated for the 500-m buffer around each grid site (table 2-1; Johnson and Belitz, 2009).

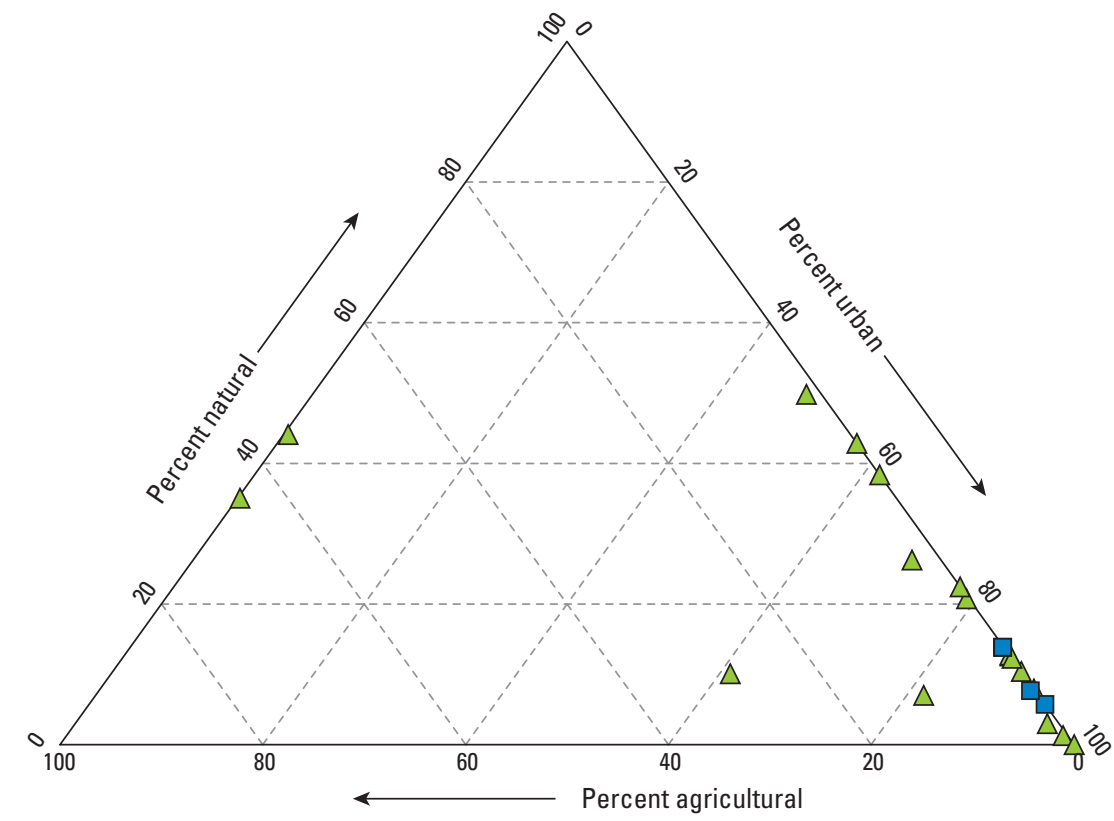

EXPLANATION

$\triangle$ Grid site

$\square$ Understanding site

(Land use based on a

500-meter-radius area around grid site)

Figure 4. Proportions natural, agricultural, and urban land use for U.S. Geological Survey (USGS) grid and USGS understanding sites, Santa Barbara study unit, 2011, California Groundwater Ambient Monitoring and Assessment (GAMA) Priority Basin Project. 


\section{Formerly Leaking Underground Fuel-Tank and Septic-Tank Densities}

The density of leaking (or formerly leaking) underground fuel tanks (LUFTs) in the Thiessen polygon (a description of a Thiessen polygon can be found in appendix 2 in the "Formerly Leaking Underground Fuel-Tank and SepticTank Densities" section) around the USGS grid and USGS understanding sites in the study unit ranged from 0.01 to 6.12 tanks per square kilometer (tanks $/ \mathrm{km}^{2}$ ), with a median value of 0.59 tanks $/ \mathrm{km}^{2}$ for the grid sites (table 2-1; California Environmental Protection Agency, 2001). The density of septic tanks in the 500-m buffers around the USGS grid sites in the study unit ranged from 0 to 35.6 tanks $/ \mathrm{km}^{2}$, with a median value of 15.2 tanks $/ \mathrm{km}^{2}$ for the grid sites (table 2-1; U.S. Census Bureau, 1990, U.S. Census ftp site, accessed May 27, 2014, at ftp://ftp2.census.gov/census_1990).

\section{Well Construction}

Well-construction information was available for all of the 18 grid sites sampled in the Santa Barbara study unit, except for 1 site missing perforation data (appendix 2). Depths of USGS grid sites ranged from 145 to $1,230 \mathrm{ft}$ below land surface (bls); the median was $438 \mathrm{ft}$ bls (fig. 5; table 2-1). Depths to the top-of-perforations ranged from 55 to $350 \mathrm{ft} \mathrm{bls,}$ and the median was $195 \mathrm{ft}$ bls. The perforation length was as much as $920 \mathrm{ft}$, and the median was $212 \mathrm{ft}$.

Well construction information also was available for the USGS understanding sites (table 2-1). The median well depth of USGS understanding sites (excluding SBU-02) was $464 \mathrm{ft}$ bls, and the median depth to top-of-perforations was $420 \mathrm{ft}$ bls (fig. 5). The sites included a cluster of three monitoring wells (SBU-03, -04, and -05) perforated at discrete intervals to observe changes in water-quality concomitant with depth.

\section{Groundwater Age}

Groundwater "age" refers to the length of time that the water has resided in the aquifer system, which is the amount of time elapsed since the water was last in contact with the atmosphere. Groundwater samples were assigned age classifications on the basis of tritium and carbon-14 $\left({ }^{14} \mathrm{C}\right)$ content of the sample (see "Groundwater-Age Classification" section in appendix 2). Groundwater in which tritium activity was greater than 0.3 tritium unit (TU) was defined as "modern," and groundwater in which tritium activity was less than 0.3 TU was defined as "pre-modern." The presence of pre-modern groundwater also was identified by using the ${ }^{14} \mathrm{C}$ data: samples in which percent modern carbon (pmc) was less than 88 percent were considered to contain a substantial component of pre-modern groundwater. Samples in which tritium activity was greater than $0.3 \mathrm{TU}$ and the pmc was less than 88 percent were classified as "mixed." Of the 22 USGS grid and USGS understanding sites in the Santa Barbara study unit with ${ }^{14} \mathrm{C}$ data, groundwater samples were classified as modern for 4 sites, mixed (evidence of both modern and pre-modern groundwater in the same sample) for 8 sites, and pre-modern for 10 sites (table 2-2, fig. 6A). Groundwater age generally increased as well depths and depths to top-ofperforations increased. Sites where groundwater samples were classified as modern or mixed generally had shallower well depths and depths to the top of perforations compared to sites from which groundwater samples were classified as premodern (fig. 6B).

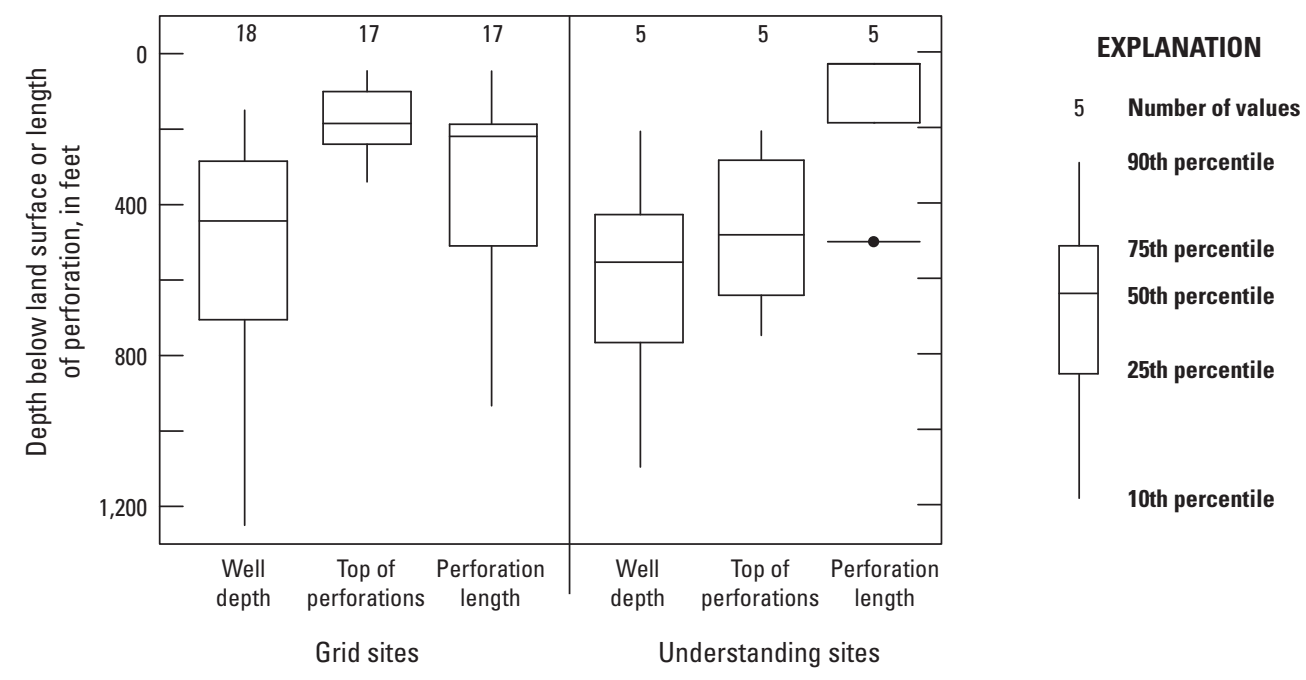

Figure 5. Well depths, depths to top-of-perforations, and perforation lengths for U.S. Geological Survey (USGS) grid and USGS understanding sites, Santa Barbara study unit, 2011, California Groundwater Ambient Monitoring and Assessment (GAMA) Priority Basin Project. 
$\boldsymbol{A}$

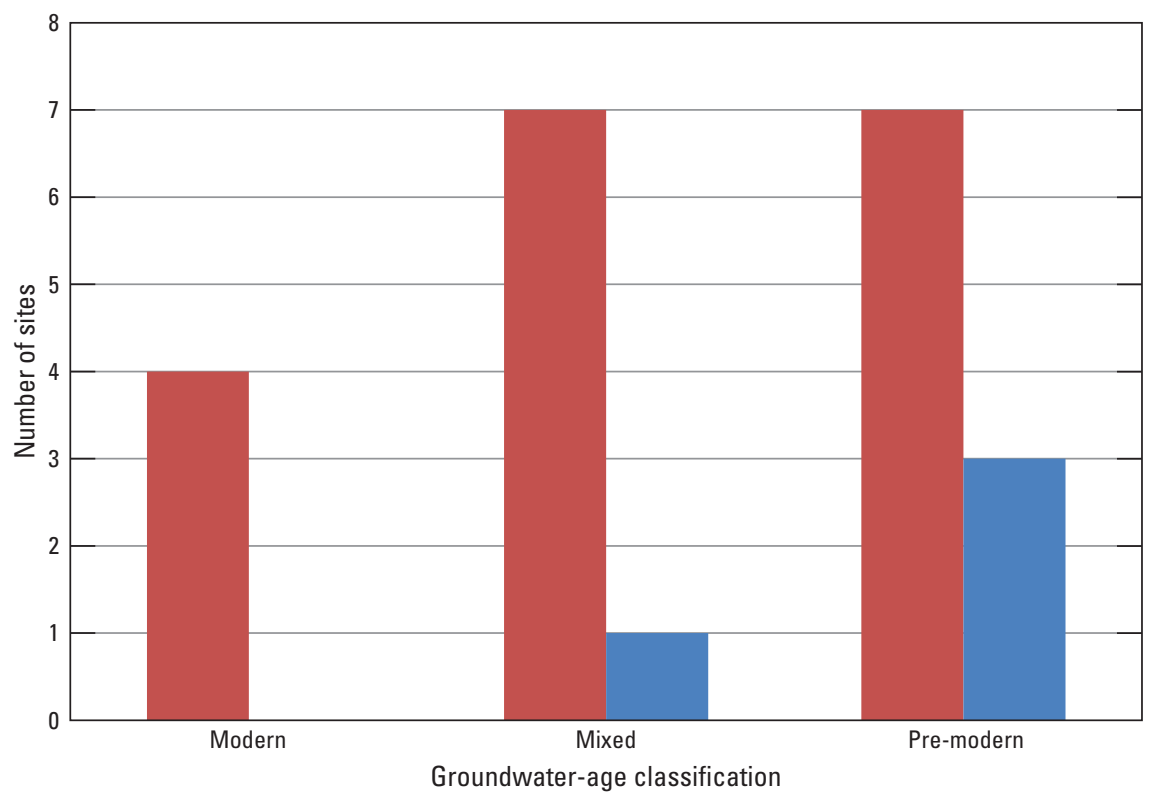

B

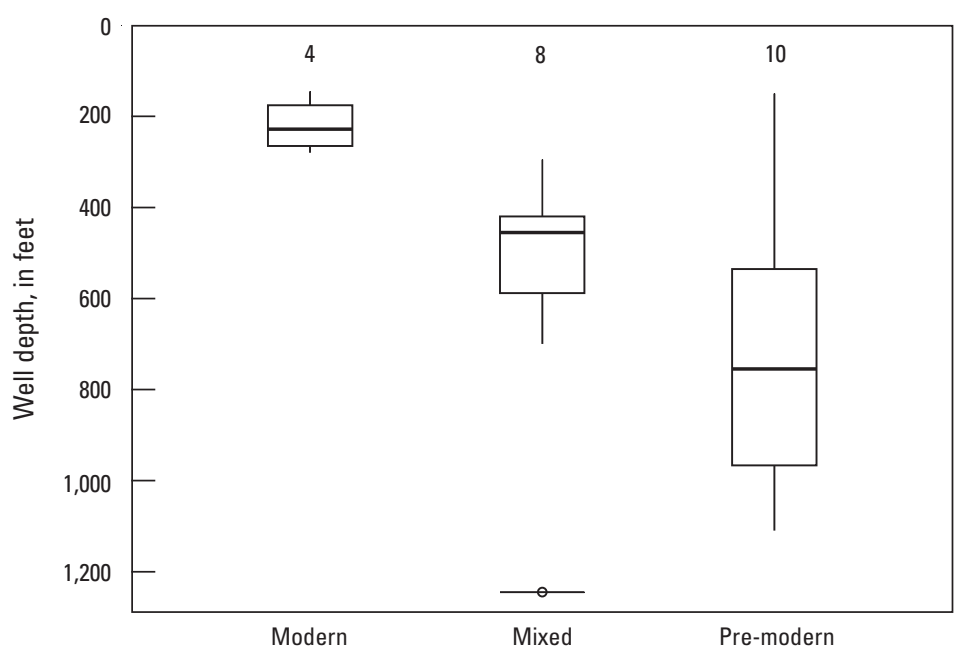

\section{EXPLANATION}

U.S. Geological Survey sites

Grid

Understanding
EXPLANATION

$5 \quad$ Number of values

90th percentile

75th percentile

50th percentile

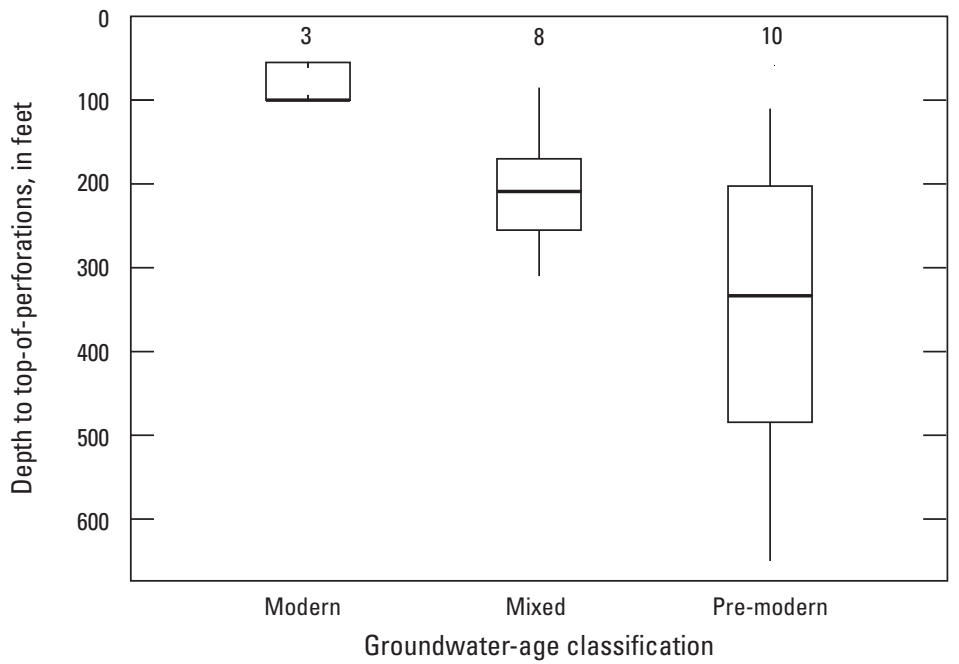

25th percentile

10th percentile

Figure 6. Groundwater age classification, Santa Barbara study unit, 2011, California Groundwater Ambient Monitoring and Assessment (GAMA) Priority Basin Project, in relation to $A$, the number of sites in each class and $B$, the well depth and depth to top-ofperforations. 


\section{Geochemical Conditions}

An abridged classification of oxidation-reduction (redox) conditions, adapted from the framework presented by McMahon and Chapelle (2008) for USGS grid, CDPH grid, and USGS understanding sites in the Santa Barbara study unit, is given in appendix 2 (table 2-3). The dissolved oxygen (DO) concentration was not available for the one CDPH grid site, and the redox for the sample was "indeterminate," a classification for groundwater samples that did not have sufficient data available to be classified as oxic, anoxic, or mixed anoxic and oxic (Jurgens and others, 2009). Redox conditions for the 18 USGS grid-site samples were mostly oxic or anoxic (fig. $7 A$ ); of the 18 sites, 8 (44 percent) were classified as oxic; 8 sites were classified as anoxic; and 2 sites (11 percent) were classified as mixed. Redox conditions for the five USGS understanding-site samples were anoxic (60 percent) and oxic (40 percent). Mixed and anoxic conditions were further subdivided into iron/sulfate reducing and nitrate/manganese reducing conditions.

Field values for $\mathrm{pH}$ were available for all grid and understanding sites (table 2-3). The $\mathrm{pH}$ value of a sample indicates the basicity or acidity of the water, which can be a control for geochemical conditions, such as the solubility of chemical species. Field $\mathrm{pH}$ values were within the SMCL-US range of $6.5-8.5$ for drinking water, with the exception of those from three USGS grid sites, where $\mathrm{pH}$ values were below 6.5 (fig. 7B).

\section{Status of Groundwater Quality}

The status assessment is intended to characterize the current quality of groundwater resources in the primary aquifer system of the Santa Barbara study unit. The primary aquifer system is defined by the depth intervals over which wells listed in the CDPH database are screened or open. The use of the term "primary aquifer system" does not imply that a discrete aquifer unit exists. In most groundwater basins, public drinking-water supply wells typically are screened or open at greater depths than are domestic wells (for example, Burow and others, 2008; Burton and others, 2012). Thus, the primary aquifer system generally corresponds to the deeper portion of the aquifer system tapped by public drinking-water supply wells. Of the wells used in status assessments for the Santa Barbara study unit, 61 percent are listed in the CDPH database and, therefore, are classified as public drinking-water supply wells. To the extent that domestic wells in the study unit are screened or open over the same depth intervals as the CDPH wells, the assessments presented in this report are also applicable to the portions of the aquifer system used for domestic drinking-water supplies.

The status assessment was designed to identify the constituents or classes of constituents most likely to be water-quality concerns on the basis of their high relativeconcentrations or their prevalence. Constituents having regulatory or non-regulatory health-based or aesthetic-based benchmarks from USGS sample analyses or the additional data from the CDPH database were included in the assessment of groundwater quality for the Santa Barbara study unit. The spatially distributed, randomized approach to site selection and data analysis yields a view of groundwater quality in which all areas of the primary aquifer system are weighted equally; regions that have a high density of groundwater use or a high density of potential contaminants were not preferentially sampled (Belitz and others, 2010).

The following discussion of the status assessment is divided into results for inorganic and organic constituents. Each part begins with a survey of how many constituents were detected at any concentration compared to the number analyzed and with a graphical summary of the relativeconcentrations of constituents detected at the grid sites. Results are presented for the subset of constituents that met criteria for selection for additional evaluation based on concentration and, for organic constituents, the frequency measured.

Aquifer-scale proportions are presented for constituent classes and for the subset of constituents that met criteria based on relative-concentrations or frequency for additional evaluation in the status assessment. The spatially weighted high aquifer-scale proportions were within the 90 -percent confidence intervals for their respective grid-based aquifer high proportions for the 19 constituents listed in table 6 , providing evidence that the grid-based and spatially weighted approaches yield statistically consistent results.

\section{Inorganic Constituents}

Inorganic constituents generally are naturally present in groundwater, although their concentrations can be influenced by human activities as well as natural factors. Of the 44 inorganic constituents (excluding geochemical and isotope tracers) analyzed by USGS-GAMA, 43 were detected in samples from the Santa Barbara study-unit grid sites (table 4). Of these 43 constituents, 24 had regulatory or non-regulatory health-based benchmarks, 7 had non-regulatory aestheticbased benchmarks, and 12 had no established benchmarks. Of the 31 inorganic constituents that had benchmarks, 10 were selected for additional evaluation in the status assessment (table 6); the 21 inorganic constituents not selected for additional evaluation were detected only at low concentrations relative to their benchmarks in samples from the grid sites. Most of the constituents that have no benchmarks are major and minor ions, which are present in nearly all groundwater.

Ten inorganic constituents were selected for additional evaluation, because they had maximum relative-concentrations greater than 0.5 (moderate or high) at grid sites (table 6): boron, fluoride, and strontium (inorganics with health-based benchmarks); nitrate plus nitrite (nutrients); gross alpha radioactivity (radioactive constituents); and chloride, iron, manganese, sulfate, and total dissolved solids (inorganics with aesthetic-based benchmarks; figs. 8, 9). 
34

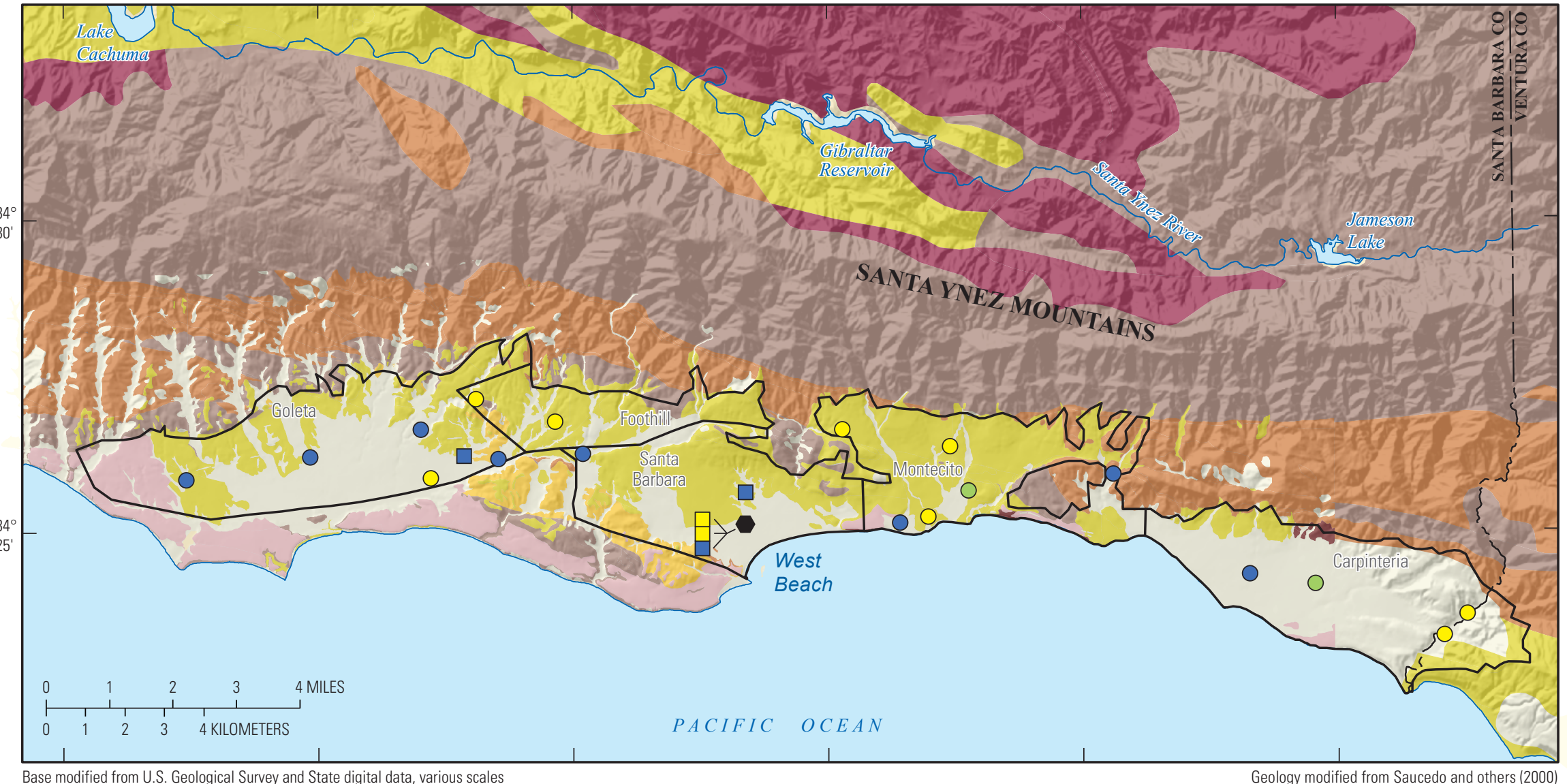

Base modified from U.S. Geological Survey and State digital data, various scales

Albers Equal Area Projection

North American Datum of 1983

\section{Geologic description}

Older alluvial deposits (Pleistocene)

19anta Barbara Formation (Pleistocene)

Casitas Formation (Pleistocene)

1) Alluvial and surficial deposits (Holocene and upper Pleistocene)

Marine-terrace deposits (upper Pleistocene)
Marine mudstone and shale (Miocene and some Pliocene)
Sandstone and mudstone in the shallower unit, with conglomerates in the lower unit (Oligocene)
Metamorphic marine sediment (Mesozoic)

\section{EXPLANATION}

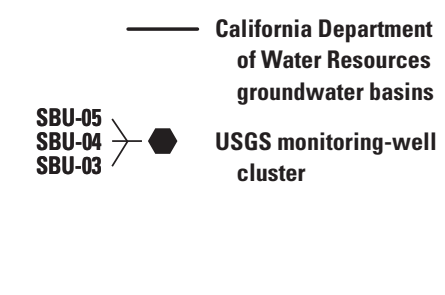

Geology modified from Saucedo and others (2000) and Minor and others (2009).

Figure 7. Geochemical conditions in the Santa Barbara study unit, 2011, California Groundwater Ambient Monitoring and Assessment (GAMA) Priority Basin Project: $A$, redox classifications at U.S. Geological Survey (USGS) grid and USGS understanding sites; $B$, pH values at USGS grid, California Department of Public Health (CDPH) grid, USGS understanding, and other CDPH sites. 


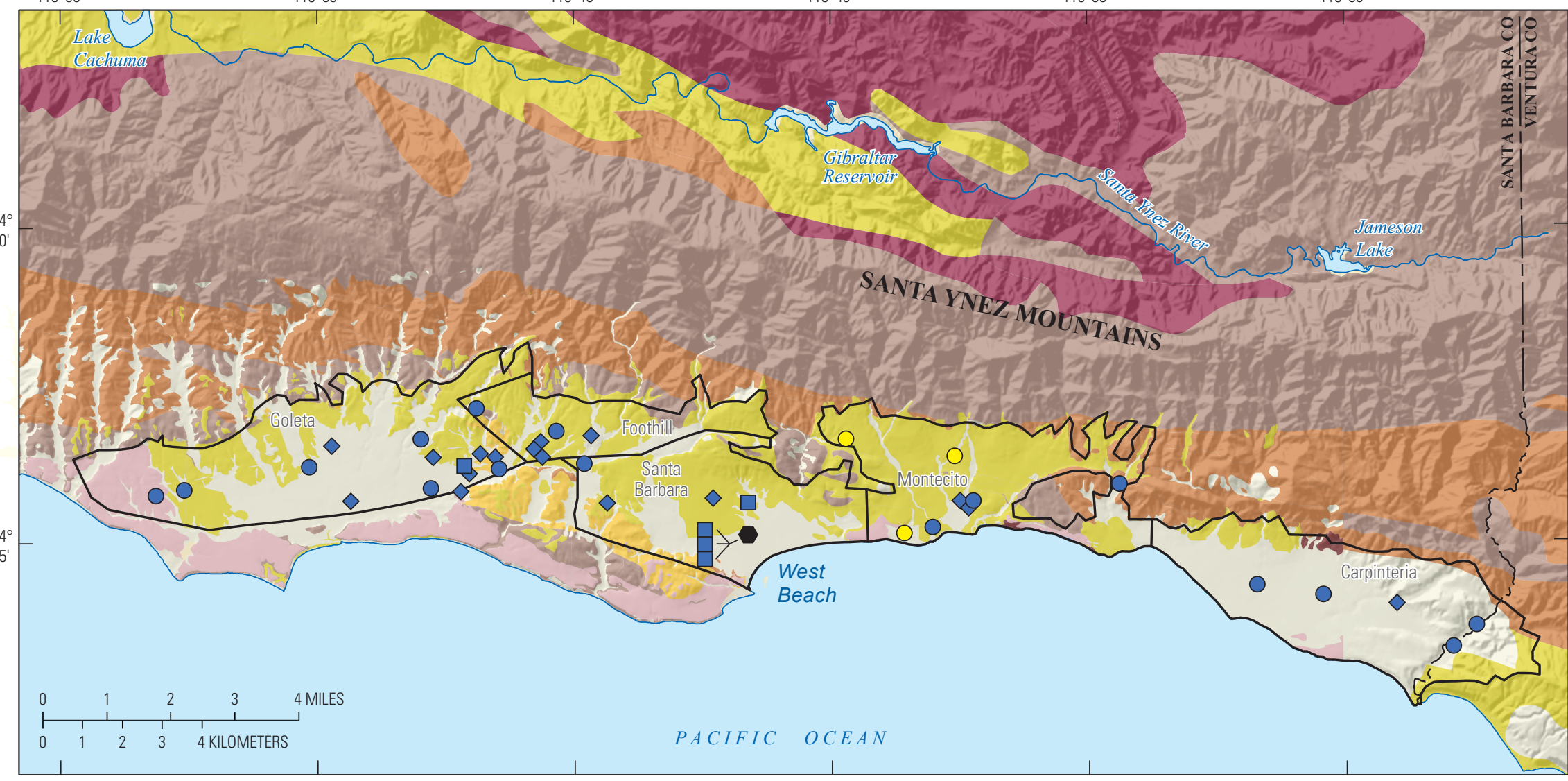

Base modified from U.S. Geological Survey and State digital data, various scales Albers Equal Area Projection

EXPLANATION

\section{Geologic description}

(3) Older alluvial deposits (Pleistocene)

3. Santa Barbara Formation (Pleistocene)

Casitas Formation (Pleistocene)

Alluvial and surficial deposits

(Holocene and upper Pleistocene)

17) Marine-terrace deposits

(upper Pleistocene)

(1) Marine mudstone and shale (Miocene and some Pliocene)

39. Sandstone and mudstone in the shallower unit, with conglomerate in the lower unit (Oligocene)

3) Metamorphic marine sediment (Mesozoic)

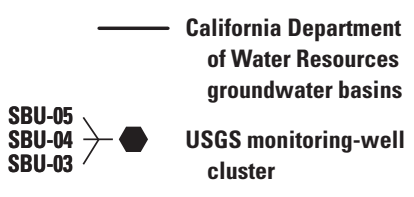
cluster
Geology modified from Saucedo and others (2000) and Minor and others (2009).

\begin{tabular}{|c|c|c|}
\hline \multicolumn{3}{|c|}{$\mathrm{pH}$ values, standard units } \\
\hline $\begin{array}{l}\text { USGS grid and } \\
\text { CDPH grid sites }\end{array}$ & $\begin{array}{l}\text { USGS } \\
\text { understanding } \\
\text { site }\end{array}$ & Other CDPH sites \\
\hline$O<6.5$ & & \\
\hline 6.5 to 7.5 & $\square 6.5$ to 7.5 & $\diamond 6.5$ to 8.0 \\
\hline
\end{tabular}




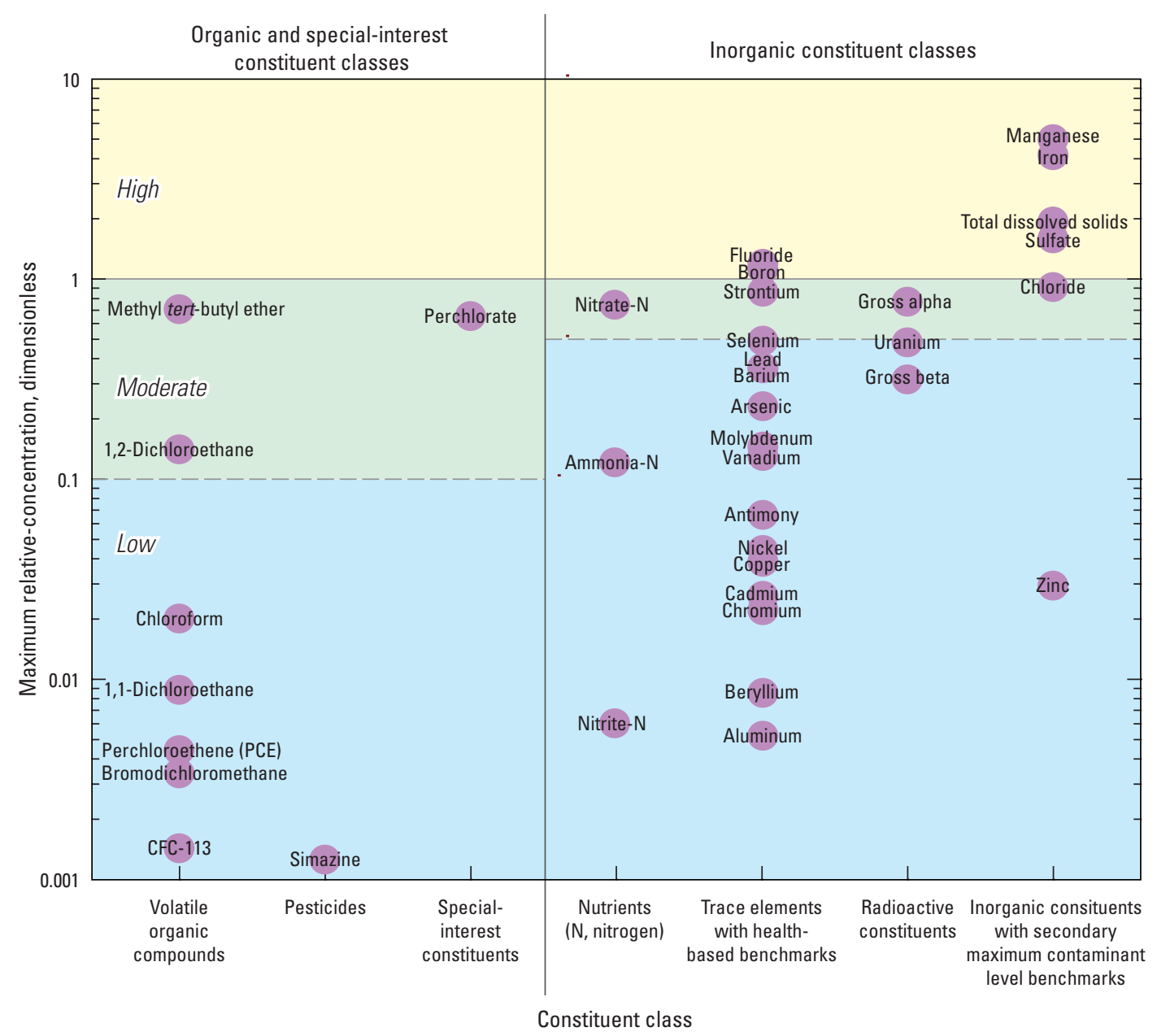

Figure 8. Maximum relative-concentrations at U.S. Geological Survey (USGS) grid and California Department of Public Health (CDPH) grid sites for detected constituents, by constituent class, Santa Barbara study unit, 2011, California Groundwater Ambient Monitoring and Assessment (GAMA) Priority Basin Project.

Inorganic constituents (trace elements and major and minor ions, nutrients, and uranium and radioactive constituents) that have human-health based benchmarks, as a group, had high relative-concentrations in 5.3 percent of the primary aquifer system, moderate relative-concentrations in 32 percent, and low relative-concentrations in 63 percent (table 7). High relative-concentrations of trace elements contributed most to the high aquifer-scale proportion. Inorganic constituents that have aesthetic-based benchmarks, as a group, had high relative-concentrations in 58 percent of the primary aquifer system, moderate relative-concentrations in 37 percent, and low relative-concentrations in 5.3 percent. Redox indicators (iron and manganese) contributed more than the salinity indicators (total dissolved solids, sulfate, and chloride) to the high aquifer-scale proportion; however, salinity indicators contributed more to the moderate aquiferscale proportion. 

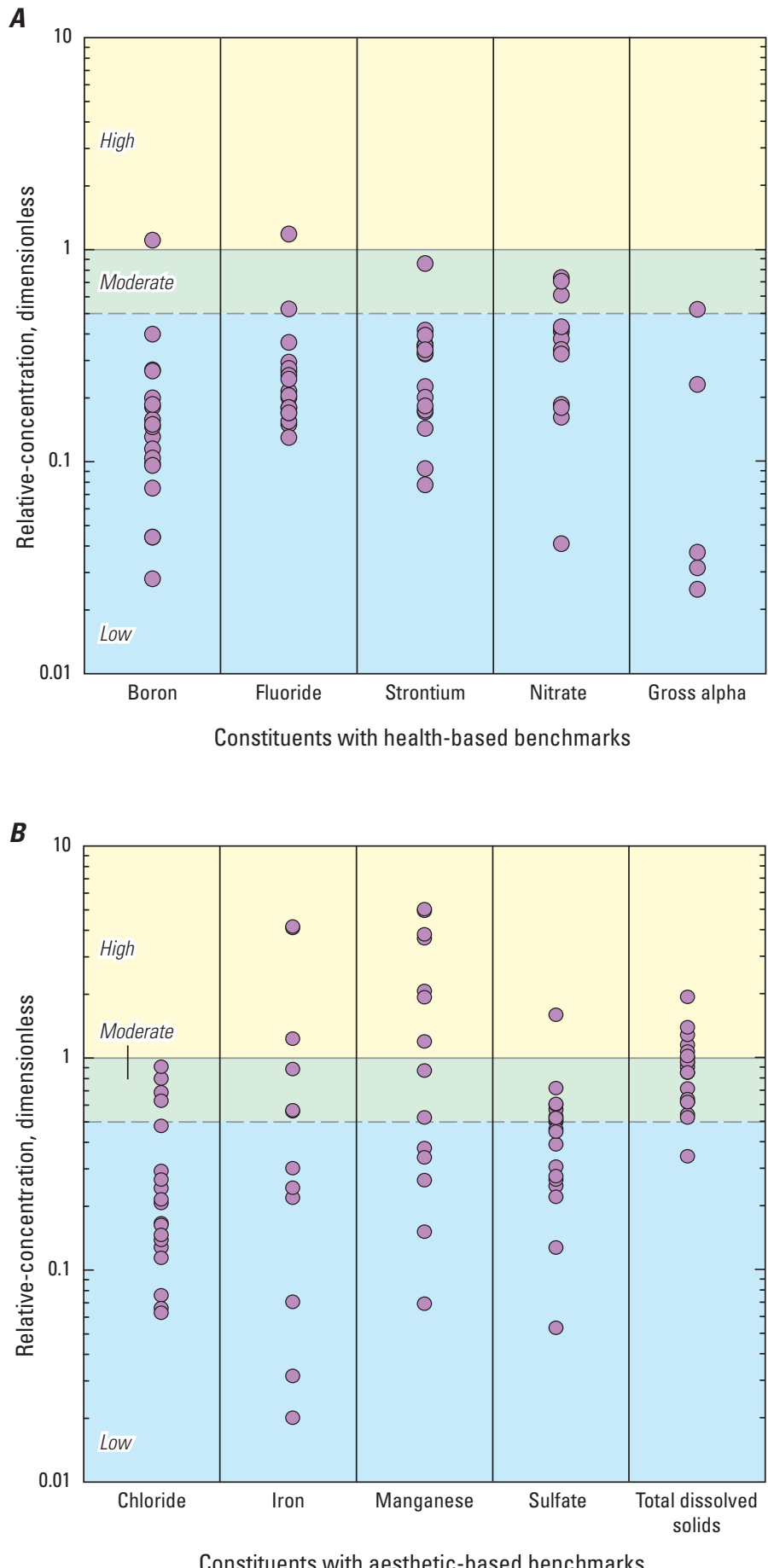

Figure 9. Relative-concentrations at U.S. Geological Survey (USGS) grid and California Department of Public Health (CDPH) grid sites in the Santa Barbara study unit, 2011, California Groundwater Ambient Monitoring and Assessment (GAMA) Priority Basin Project for selected inorganic constituents with $A$, health-based benchmarks, and $B$, aesthetic-based benchmarks.

\section{Trace Elements and Major and Minor lons}

Trace elements and major ions primarily have natural sources. Trace elements and major and minor ions that have health-based benchmarks, as a class, were present at high relative-concentrations in 5.3 percent, and at moderate relative-concentrations in 11 percent, of the primary aquifer system in the Santa Barbara study unit (table 7). High relativeconcentrations for boron and fluoride were detected at a USGS grid site near the eastern boundary of the Montecito groundwater basin (figs. $10 A-B$ ); fluoride was detected also at moderate concentration at a USGS grid site on the southern border of the groundwater basin. Strontium was present only at moderate and low relative-concentrations in the study unit (fig. 9A).

Boron is a naturally present metalloid element that is highly soluble in water. Natural sources of boron include evaporate minerals, such as borax, ulexite, and colemanite, and boron-bearing silicate minerals, such as tourmaline, which are found primarily in igneous rocks (Hem, 1985; Klein and Hurlbut, 1993). The boron concentration in seawater is approximately 4,500 micrograms per liter $(\mu \mathrm{g} / \mathrm{L})$. Boron was present at high relative-concentrations in 5.3 percent of the primary aquifer system and was not detected at moderate relative-concentrations (table 6).

Sources of fluoride in groundwater can be both natural and anthropogenic. Fluoride minerals can be found in igneous and sedimentary rocks. Fluoride frequently is associated with volcanic gases, and, in some areas, this may be an important source to groundwater (Hem, 1985). Fluoride often is added to drinking-water systems and toothpaste for the prevention of dental decay (Centers for Disease Control and Prevention, 2001). Fluoride was present at high relative-concentrations in 5.3 percent, and at moderate relative-concentrations in 5.3 percent, of the primary aquifer system (table 6 ).

Strontium was not detected at high relativeconcentrations and was present at moderate relativeconcentrations in 5.6 percent of the primary aquifer system (table 6). Lead was reported at a high relative-concentration in one sample in the CDPH historical database (table 5), but not during the current period of study (January 24, 2008, through January 23, 2011). 
$30^{\circ}$

$34^{\circ}$

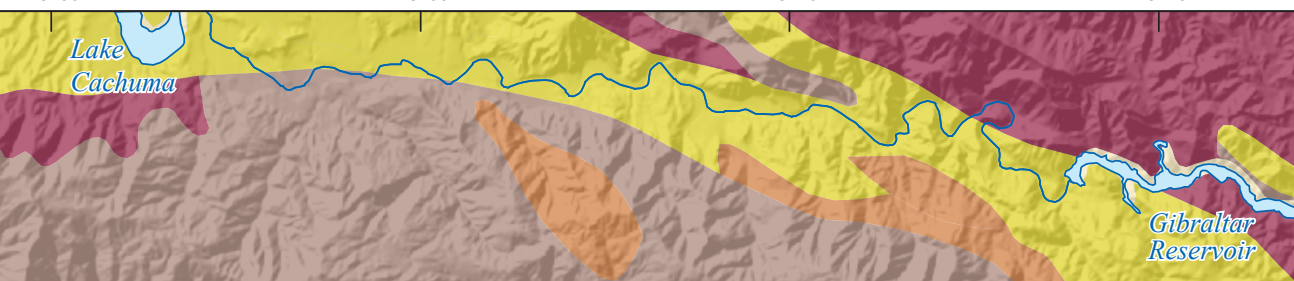

30 (1)

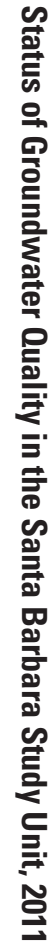

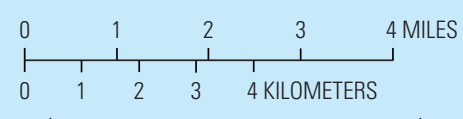

Base modified from U.S. Geological Survey and State digital data, various scales Albers Equal Area Projection North American Datum of 1983

\section{Geologic description}

2) Older alluvial deposits (Pleistocene)

19. Santa Barbara Formation (Pleistocene)

Casitas Formation (Pleistocene)

Alluvial and surficial deposits

(Holocene and upper Pleistocene)

3) Marine-terrace deposits (upper Pleistocene)
Marine mudstone and shale (Miocene and some Pliocene)
Sandstone and mudstone in the shallower unit, with conglomerate in the lower unit (Oligocene) Metamorphic marine sediment (Mesozoic)

P A C I F I C

$O C E A N$

\section{EXPLANATION} cluster

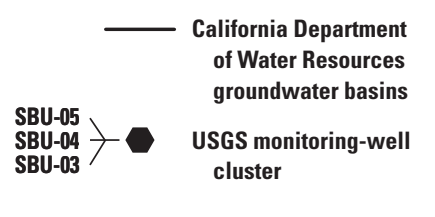

ifornia Department

$\stackrel{\mathrm{SBU}-05}{\mathrm{SBU}-04} \rightarrow \quad$ USGS monitoring-well

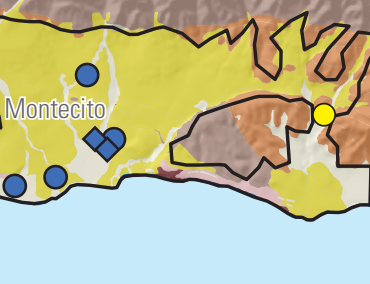

S

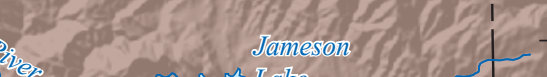

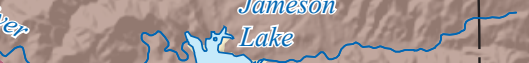
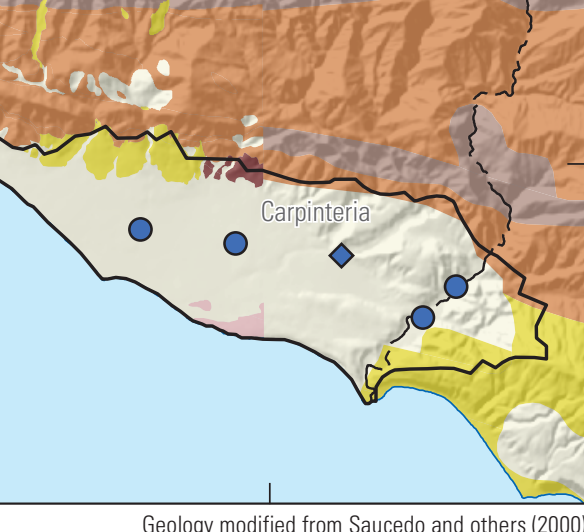

and Minor and others (2009).

Boron in micrograms per liter

Relative- USGS grid and USGS understanding Other CDPH concentration CDPH grid sites site sites

Low $(\leq 500) \quad 0$

High $(>1,000)$

Figure 10. Relative-concentrations in groundwater at U.S. Geological Survey (USGS) grid, California Department of Public Health (CDPH) grid, USGS understanding, and other CDPH sites, Santa Barbara study unit, 2011, California Groundwater Ambient Monitoring and Assessment (GAMA) Priority Basin Project, of $A$, boron and $B$, fluoride. 


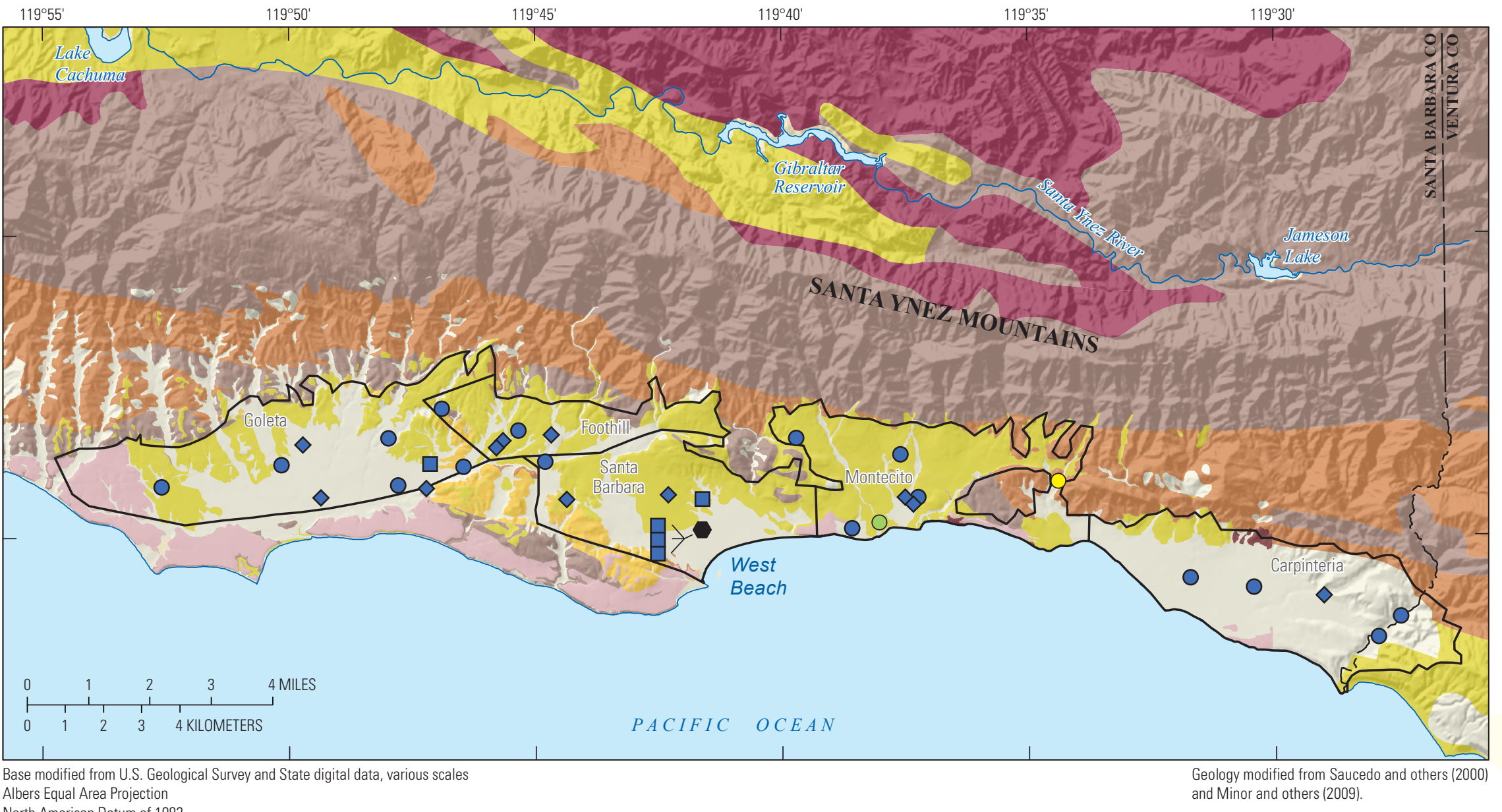

$$
\text { North American Datum of } 1983
$$

\section{Geologic description}

Older alluvial deposits (Pleistocene)

3) Santa Barbara Formation (Pleistocene)

Casitas Formation (Pleistocene)

Alluvial and surficial deposits

(Holocene and upper Pleistocene)

Marine-terrace deposits (upper Pleistocene)

\section{EXPLANATION}

Marine mudstone and shale (Miocene and some Pliocene)

19andstone and mudstone in the shallower unit, with conglomerates in the lower unit (Oligocene)

19. Metamorphic marine sediment (Mesozoic)

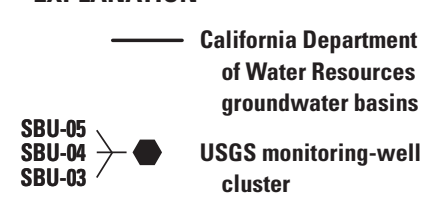

SBU-04
SBU-03

\begin{tabular}{rccc} 
& \multicolumn{3}{c}{ Fluoride, in milligrams per liter } \\
$\begin{array}{r}\text { Relative- } \\
\text { concentration }\end{array}$ & $\begin{array}{c}\text { USGS grid and } \\
\text { CDPH grid sites }\end{array}$ & USGS understanding & Other CDPH \\
Low $(\leq 1)$ & $\bigcirc$ & & sites \\
Moderate $(>1$ to 2) & $\bigcirc$ & & $\diamond$ \\
High (>2) & $\bigcirc$ &
\end{tabular}

Figure 10. - Continued 


\section{Nutrients}

Forms of nitrogen in groundwater include dissolved nitrate, nitrite, and ammonia. Certain bacteria and algae convert nitrogen from the atmosphere to nitrate, which is an important nutrient for plants. Nitrate also is present in precipitation (Hem, 1970), partly from nitrogen oxides released during the combustion of fossil fuels (Kendall, 1998). Anthropogenic sources of nitrate include inorganic fertilizers applied for agriculture and the waste produced by livestock, which can leach to groundwater when animals are present in large numbers (Hem, 1985; Sparks, 2003). Septic and municipal sewage systems also contain nitrogenous waste that can leach into groundwater (Sparks, 2003).

Nutrients, as a class, had high relative-concentrations in 1.3 percent (spatially weighted) of the primary aquifer system in the Santa Barbara study unit and moderate aquiferscale proportions in 16 percent of the primary aquifer system (table 7). Nitrate plus nitrite, as nitrogen (referred to as nitrate in this report) was the only nutrient present at high or moderate concentrations (table 6). Moderate relative-concentrations of nitrate generally were detected in the eastern portion of the study unit, and the only high relative-concentration of nitrate was detected at a CDPH site in the Foothill Basin (fig. 11). Nitrate was not detected in groundwater from most USGS-GAMA and CDPH sites in the Goleta groundwater basin.

\section{Uranium and Radioactive Constituents}

Most of the radioactivity in groundwater comes from the decay of uranium and thorium naturally present in the rocks or sediments that compose the aquifers. Radioactive decay of uranium and thorium isotopes produces long series of radioactive daughter products, including isotopes of radium, uranium, and radon. These elements have different chemical properties, and their solubility in groundwater varies with geochemical conditions, water chemistry, and aquifer mineralogy (for example, Hem, 1985). This study included data for the individual constituents uranium and radon-222 and for gross alpha and beta radioactivities, which are measures of the activities of all radioactive elements in the water sample that decay by alpha or beta particle emission, respectively. Uranium was compared to the MCL-US of $30 \mu \mathrm{g} / \mathrm{L}$, rather than to the MCL-CA of 20 picocurie per liter (pCi/L), and gross alpha radioactivity was not adjusted for uranium activity for comparison with the MCL-US of $15 \mathrm{pCi} / \mathrm{L}$ (see appendix 1).
Uranium and radioactive constituents were not detected at high relative-concentrations in the Santa Barbara study unit, but were present at moderate relative-concentrations in 17 percent of the primary aquifer system (table 7; fig. 9A). The constituent present at moderate relative-concentrations was gross alpha radioactivity (table 6). Uranium was reported at high relative-concentration at one site in the CDPH historical database (table 5).

\section{Inorganic Constituents with Aesthetic-Based Benchmarks}

Inorganic constituents that have aesthetic-based benchmarks affect the aesthetic properties of water, such as taste, color, and odor, or can cause other problems, such as scaling and staining. These constituents include salinity indicators, such as chloride, sulfate, and total dissolved solids (TDS), and trace elements, such as iron and manganese. Natural sources of salinity in groundwater include weathering and dissolution of minerals from soils, sediments, and rocks; upwelling of connate saline groundwater from Tertiaryage rock; mixing with saline or brackish water from the ocean, estuaries, or saline lakes; interactions with marine or lacustrine sediments; mixing with hydrothermal solutions; oil fields; and concentration by evapotranspiration of shallow groundwater (Hem, 1985). Anthropogenic sources of salinity in groundwater include recharge of water used for irrigation, wastewater discharge, seawater intrusion, and evaporation.

Potential natural sources of iron and manganese to groundwater include the dissolution of igneous and metamorphic rocks and various secondary minerals and the reductive dissolution of metal-oxides that coat sedimentary rocks (Hem, 1970). Potential anthropogenic sources of these constituents in groundwater include effluents associated with the steel and mining industries (Reimann and de Caritat, 1998) and soil amendments in the form of iron and manganese sulfates, which are added to deficient soils to stimulate crop growth.

As a class, inorganic constituents (trace elements and major and minor ions) that have aesthetic-based benchmarks (SMCLs) were present at high relative-concentrations in 58 percent, and at moderate relative-concentrations in 37 percent, of the primary aquifer system in the Santa Barbara study unit (table 7). Salinity indicators (TDS and sulfate) and redox indicators (iron and manganese) were present at high relative-concentrations in the primary aquifer system in the Santa Barbara study unit (fig. 9B). 


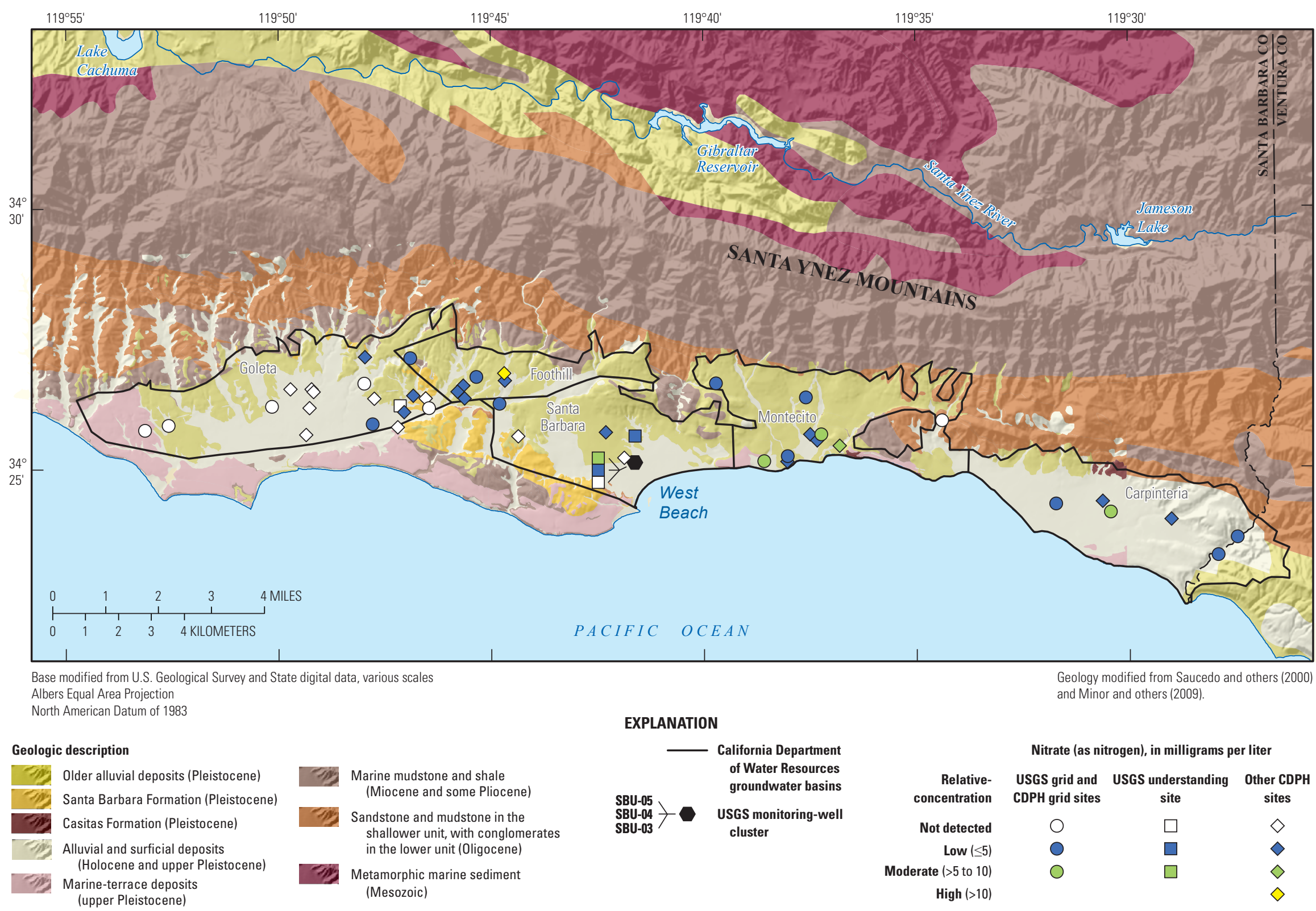

Figure 11. Relative-concentrations of nitrate at U.S. Geological Survey (USGS) grid, California Department of Public Health (CDPH) grid, USGS understanding, and other CDPH sites, Santa Barbara study unit, 2011, California Groundwater Ambient Monitoring and Assessment (GAMA) Priority Basin Project. 


\section{Chloride, Sulfate, and Total Dissolved Solids}

Salinity indicators were present at high relativeconcentrations in 32 percent of the primary aquifer system in the Santa Barbara study unit and at moderate relativeconcentrations in 63 percent (table 7). In 32 percent of the primary aquifer system, TDS was present at high relativeconcentrations, and it was present at moderate relativeconcentrations in 63 percent (table 6). Sulfate was present at high relative-concentrations in 5.3 percent of the primary aquifer system of the Santa Barbara study unit and at moderate relative-concentration in 37 percent. Chloride was present at moderate relative-concentrations in 21 percent of the primary aquifer system. High relative-concentrations of TDS and moderate relative-concentrations of sulfate and chloride were detected at sites mostly in the Goleta, Foothill, and Montecito groundwater basins (figs. 12A-C). Salinity indicators, as a class, had the greatest moderate and high aquifer-scale proportions of the constituent classes in the study unit and, therefore, are discussed further in this section, along with some potential explanatory factors.

Major-ion data for USGS grid and USGS understanding sites were plotted on a Piper diagram (Piper, 1944; Hem, 1985) and grouped by TDS concentrations to define groundwater types in the Santa Barbara primary aquifer system as a function of salinity (fig. 13). Piper diagrams show the relative abundance of major cations and anions as a percentage of the total ion content of the water. Samples from most of the grid sites ( 84 percent) and two of the six understanding sites had mixed cation-mixed anion type water (no single ion accounted for more than 60 percent of total cations or anions). Groundwater samples that contained moderate relative-concentrations of TDS were dominated by bicarbonate/sulfate chemistry, whereas samples that had high relative-concentrations of TDS contained more chloride relative to sulfate and bicarbonate. With the exception of samples from two sites (SBU-02 and SB-14), calcium was the dominant cation in the study unit, regardless of the salinity of the water.

Stable isotope ratios of hydrogen $\left(\delta^{2} \mathrm{H}\right)$ and oxygen $\left(\delta^{18} \mathrm{O}\right)$ were analyzed for samples from USGS grid and USGS understanding sites in the Santa Barbara study unit to aid in the interpretation of the source and movement of groundwater in the aquifer. The stable isotopic composition of water is expressed as the ratios of the heavier isotopes (deuterium and oxygen-18) to the lighter isotopes (hydrogen and oxygen-16, respectively) relative to the international standard composition of ocean water known as Vienna Standard Mean Ocean Water (VSMOW; Coplen and others, 2002). In figure 14, stable isotope ratios for the Santa Barbara study unit were plotted along with the global meteoric water line (GMWL) of $\delta^{2} \mathrm{H}=8 \delta^{18} \mathrm{O}+10$, which represents the linear relationship of the two isotope ratios in precipitation that has not been evaporated (Craig, 1961).

The stable isotope ratios of groundwater samples in the Santa Barbara study unit included a narrow range of $\delta^{18} \mathrm{O}$ values ( -6.3 to -5.4 per mil) and plotted near or above the GMWL (fig. 14). These results are similar to the stable isotopic composition of groundwater seeps in fractured rock of the Santa Ynez Mountains (Rademacher and others, 2003). The $\delta^{18} \mathrm{O}$ values for the groundwater seeps ranged from -7.7 to -6.6 per mil and reflected the average isotopic composition of local precipitation. Groundwater samples from the Santa Barbara study unit that had high concentrations of salinity indicators generally had slightly heavier isotopic composition than the rest of the groundwater samples (fig. 14); however samples did not plot significantly to the right of the GMWL as would be expected for waters that have undergone evaporation.

The groundwater from USGS understanding site SBU-02 had a chemical composition unlike that from the other sites sampled in the Santa Barbara study unit. SBU-02 belongs to a cluster of monitoring wells perforated at discrete intervals corresponding to four confined zones in the Santa Barbara groundwater basin, as described by Martin (1984). The deep zone (SBU-02) is characterized by sodium-chloride type water that has high concentrations of TDS, barium, and boron and low sulfate concentration. The deep zone is not believed to be affected by seawater intrusion, which is supported by results from the SBU-02 groundwater sample. The SBU-02 sample had concentrations of TDS, chloride, and sodium $(2,640 \mathrm{mg} / \mathrm{L}$, $1,440 \mathrm{mg} / \mathrm{L}$, and $813 \mathrm{mg} / \mathrm{L}$, respectively) at $7.5-7.7$ percent the concentrations typically found in seawater $(35,000 \mathrm{mg} / \mathrm{L}$, $19,000 \mathrm{mg} / \mathrm{L}$, and 10,500 mg/L, respectively; Hem, 1985). However, the high concentration of barium in the deep zone compared to the composition of seawater $(4.77 \mathrm{mg} / \mathrm{L}$ in SBU-02; $0.02 \mathrm{mg} / \mathrm{L}$ in seawater), and low concentration of sulfate $(32.2 \mathrm{mg} / \mathrm{L}$ in SBU-02; $2,700 \mathrm{mg} / \mathrm{L}$ in seawater), suggest a source of high salinity in the deep zone other than mixing with seawater. The lower and middle zones (SBU-03 and SBU-04, respectively) produced groundwater that had low chloride and sulfate concentrations and was pre-modern in age. Groundwater from the upper zone (SBU-05) also had low concentrations of salinity indicators. Groundwater from SBU-05 had moderate relative-concentrations of nitrate, solvents, and perchlorate which may be evidence of surficial contamination from anthropogenic sources near the monitoring site (fig. 11; see the "Organic and Special-Interest Constituents" section for solvents and perchlorate results).

In a study by Martin (1984), several groundwater sites in the Santa Barbara groundwater basin were monitored for the effects of increased groundwater pumping on water quality near the coast, as part of a basin-testing program. Results were used to characterize the quality and quantity of groundwater resources in the Santa Barbara groundwater basin and determine the best approach to controlling saltwater intrusion. Two potential sources of high salinity were seawater intrusion and groundwater from the deep zone of the Santa Barbara Formation. Ion ratios (chloride to sulfate and chloride to boron) and concentrations (barium and sulfate) were analyzed to determine the primary source of contamination for groundwater sites that had high TDS concentrations. 


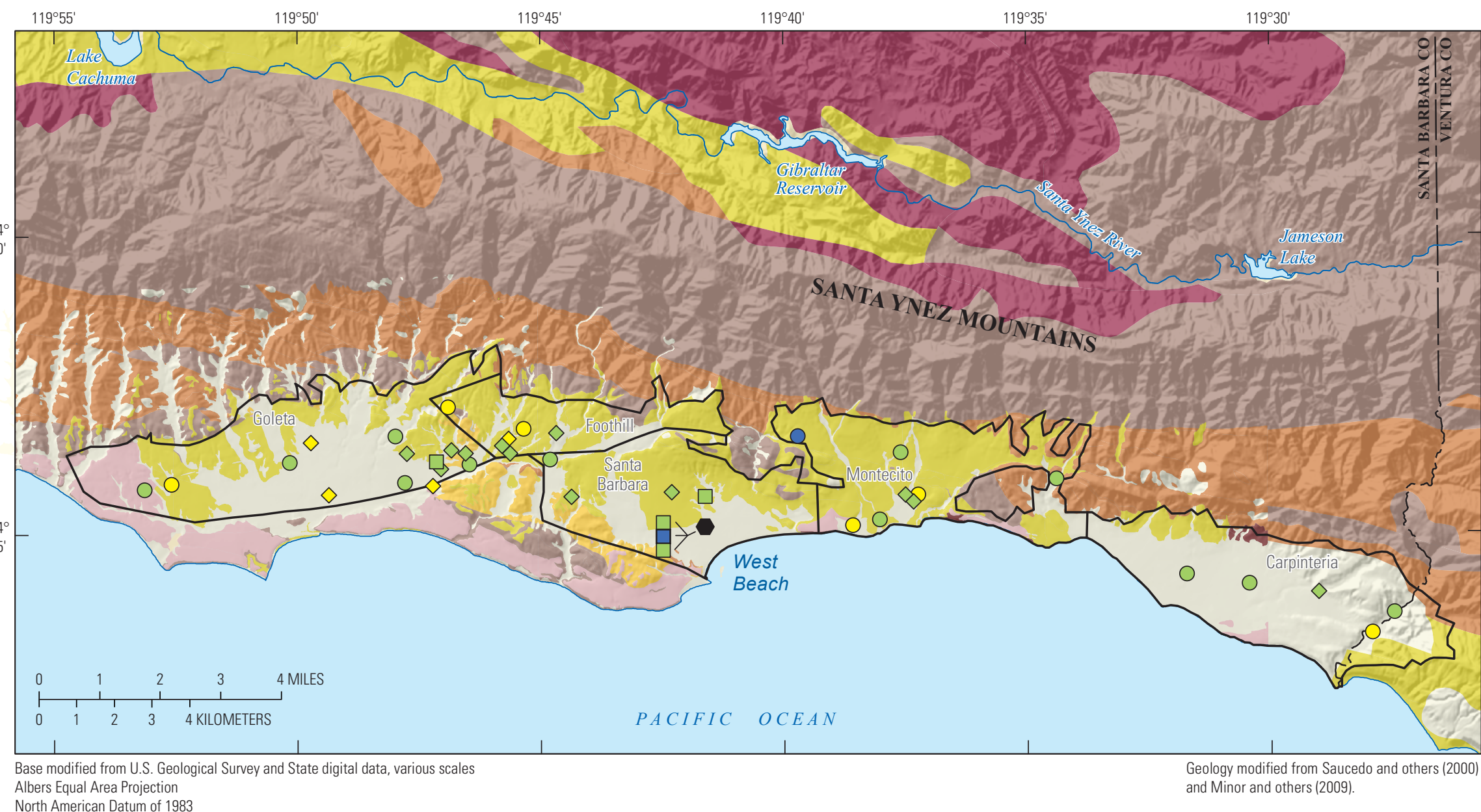

Geologic description

EXPLANATION

3) Older alluvial deposits (Pleistocene)

Santa Barbara Formation (Pleistocene)

Casitas Formation (Pleistocene)

Alluvial and surficial deposits

(Holocene and upper Pleistocene)

(3) Marine-terrace deposits (upper Pleistocene)

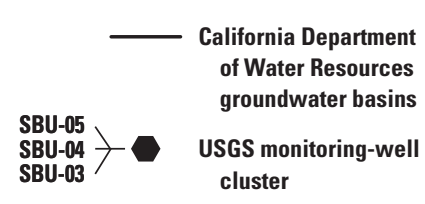
(Miocene and some Pliocene)

Sandstone and mudstone in the shallower unit, with conglomerates in the lower unit (Oligocene)

32. Metamorphic marine sediment (Mesozoic)
Total dissolved solids (TDS), in milligrams per liter

Relativeconcentration

Low $(\leq 500)$

Moderate $(>500$ to 1,000$)$

High $(>1,000)$
USGS grid and USGS understanding Other CDPH

O

Figure 12. Relative-concentrations at U.S. Geological Survey (USGS) grid, California Department of Public Health (CDPH) grid, USGS understanding, and other CDPH sites, Santa Barbara study unit, 2011, California Groundwater Ambient Monitoring and Assessment (GAMA) Priority Basin Project of $A$, total dissolved solids (TDS); $B$, sulfate; $C$, chloride; $D$, iron; and $E$, manganese. 
34

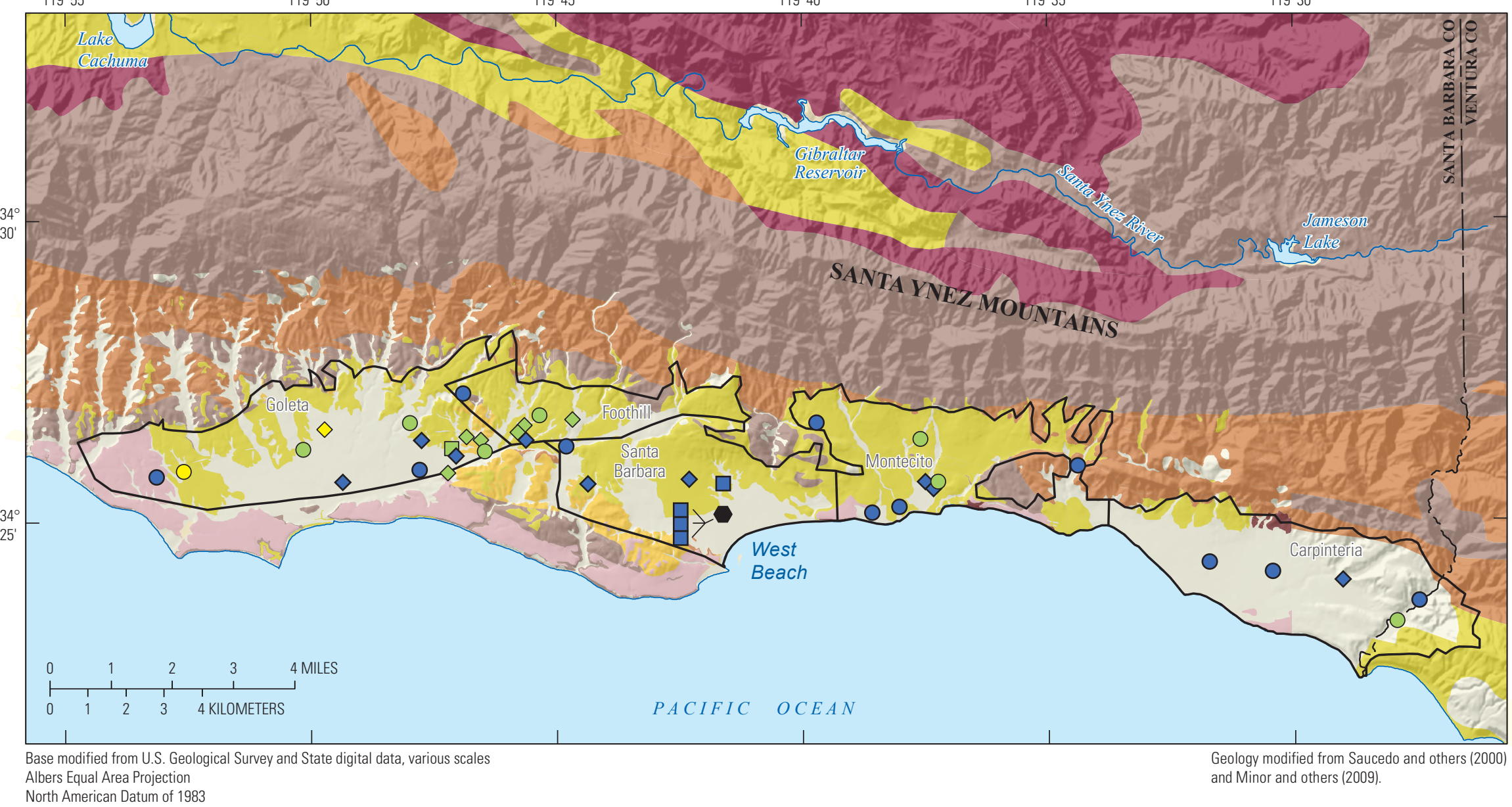

Geologic description

Older alluvial deposits (Pleistocene)

3) Santa Barbara Formation (Pleistocene)

Casitas Formation (Pleistocene)

19. Alluvial and surficial deposits (Holocene and upper Pleistocene)

(19) Marine-terrace deposits (upper Pleistocene)

\section{EXPLANATION}

California Department of Water Resources groundwater basins

SBU-05 SBU-04 (Miocene and some Pliocene)

Sandstone and mudstone in the shallower unit, with conglomerates

etamorphic marine sediment (Mesozoic) monitoring-well cluster

Sulfate, in milligrams per liter

$\begin{array}{rccc}\begin{array}{r}\text { Relative- } \\ \text { concentration }\end{array} & \begin{array}{c}\text { USGS grid and } \\ \text { CDPH grid sites }\end{array} & \begin{array}{c}\text { USGS understanding } \\ \text { site }\end{array} & \begin{array}{c}\text { Other CDPH } \\ \text { sites }\end{array} \\ \text { Low }(\leq 250) & \bigcirc & \square & \diamond \\ \text { Moderate }(>250 \text { to } 500) & \bigcirc & \square & \diamond \\ \text { High }(>500) & \bigcirc & & \diamond\end{array}$

Figure 12. - Continued 


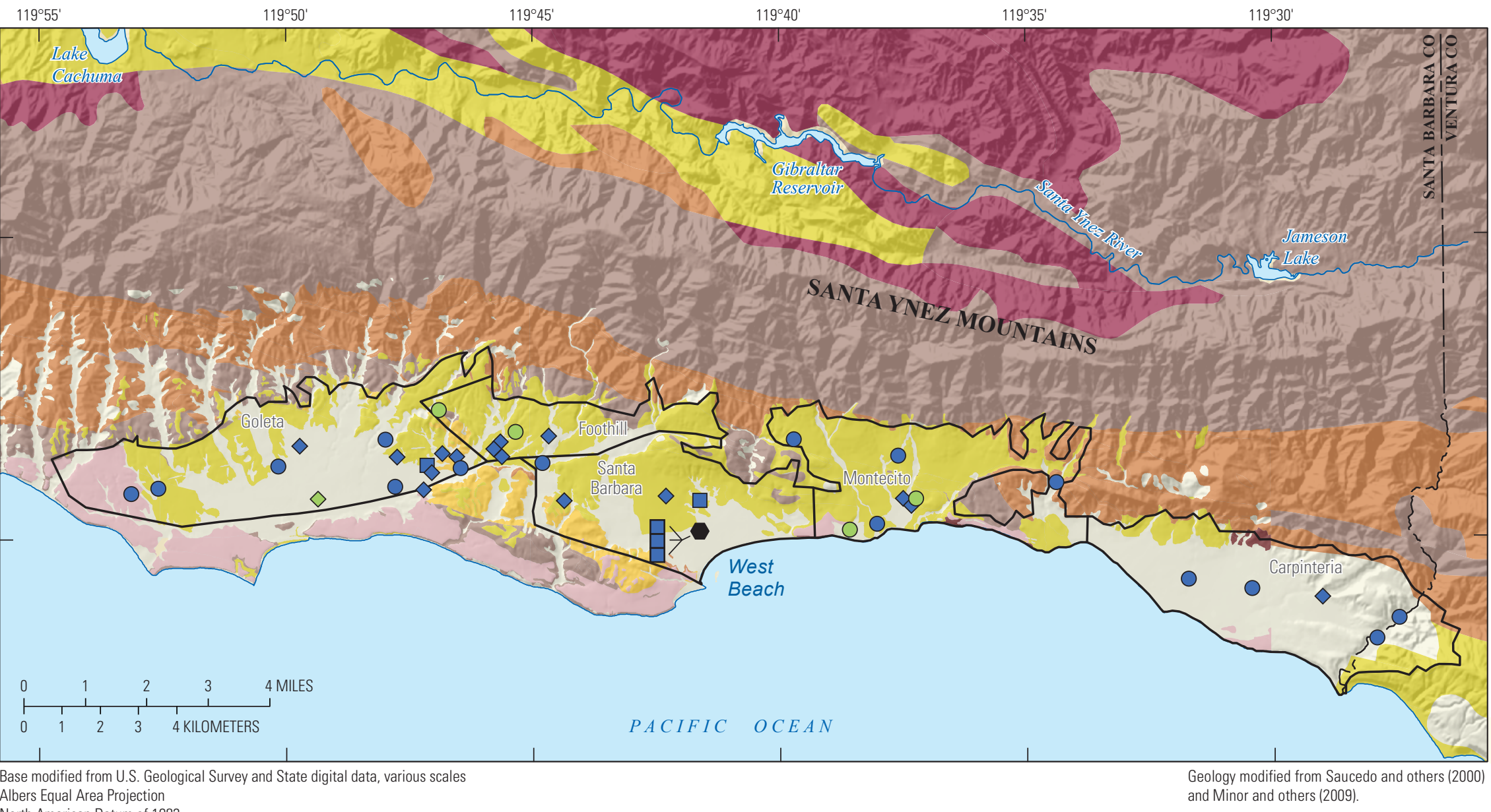

North American Datum of 1983

EXPLANATION

Geologic description

3lder alluvial deposits (Pleistocene)

Santa Barbara Formation (Pleistocene)

Casitas Formation (Pleistocene)

Alluvial and surficial deposits

(Holocene and upper Pleistocene)

(1) Marine-terrace deposits (upper Pleistocene)
17) Marine mudstone and shale (Miocene and some Pliocene)

3) Sandstone and mudstone in the shallower unit, with conglomerates in the lower unit (Oligocene)

192. Metamorphic marine sediment (Mesozoic)

\begin{tabular}{|c|c|c|c|c|c|}
\hline \multirow{3}{*}{$\begin{array}{l}\text { SBU-05 } \\
\text { SBU-04 } \\
\text { SBU-03 }\end{array}$} & \multirow{2}{*}{$\begin{array}{l}\text { California Department } \\
\text { of Water Resources } \\
\text { groundwater basins }\end{array}$} & \multirow[b]{2}{*}{$\begin{array}{r}\text { Relative- } \\
\text { concentration }\end{array}$} & \multicolumn{3}{|c|}{ Chloride, in milligrams per liter } \\
\hline & & & $\begin{array}{l}\text { USGS grid and } \\
\text { CDPH grid sites }\end{array}$ & $\begin{array}{l}\text { USGS understanding } \\
\text { site }\end{array}$ & $\begin{array}{l}\text { Other CDPH } \\
\text { sites }\end{array}$ \\
\hline & $\begin{array}{l}\text { USGS monitoring-well } \\
\text { cluster }\end{array}$ & Low $(\leq 250)$ & 0 & $\square$ & 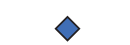 \\
\hline & & Moderate $(>250$ to 500$)$ & 0 & $\square$ & $\diamond$ \\
\hline
\end{tabular}

Figure 12. - Continued 


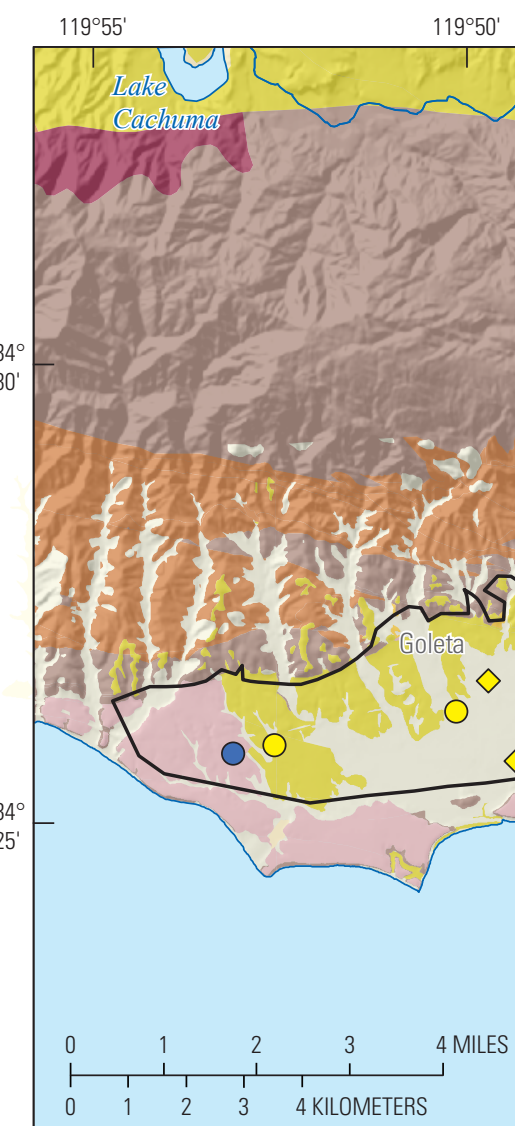

$\frac{1}{\text { Base modified from U.S. Geological Survey and State digital data, various scales }}$ Albers Equal Area Projection North American Datum of 1983

\section{Geologic description}

(1) Older alluvial deposits (Pleistocene)

3) Santa Barbara Formation (Pleistocene)

Casitas Formation (Pleistocene)

19. Alluvial and surficial deposits (Holocene and upper Pleistocene)

17) Marine-terrace deposits (upper Pleistocene)

Figure 12. - Continued

\section{PACIFIC OCEAN}

\section{EXPLANATION}

California Department
of Water Resources
groundwater basins

Marine mudstone and shale (Miocene and some Pliocene)

Sandstone and mudstone in the shallower unit, with conglomerates in the lower unit (Oligocene)

Metamorphic marine sediment (Mesozoic)

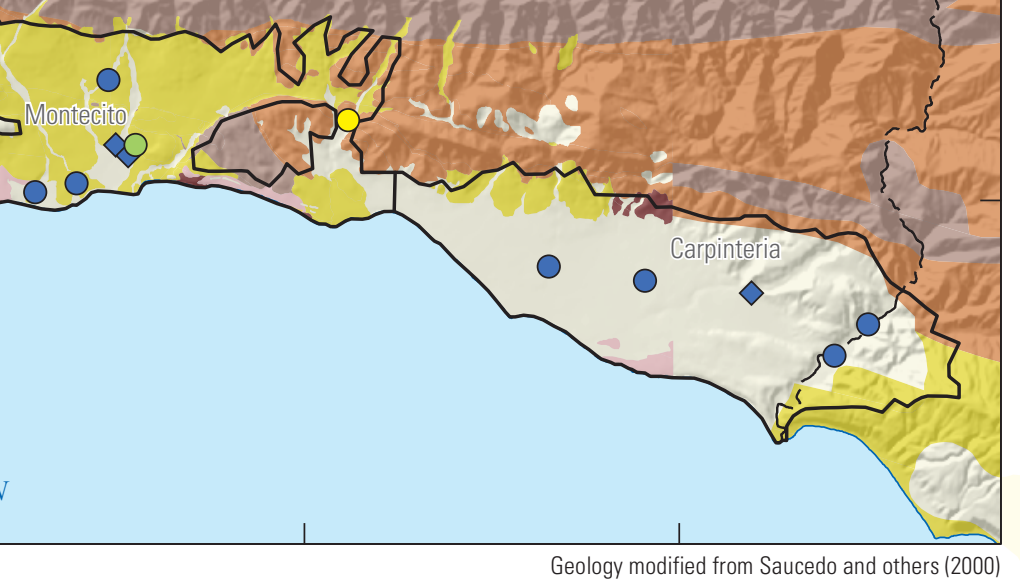
and Minor and others (2009).

Iron, in micrograms per liter

Relative- USGS grid and USGS understanding 0ther CDPH concentration CDPH grid sites site Low $(\leq 150)$ Moderate $(>150$ to 300$)$ High $(>300)$

0
0
0




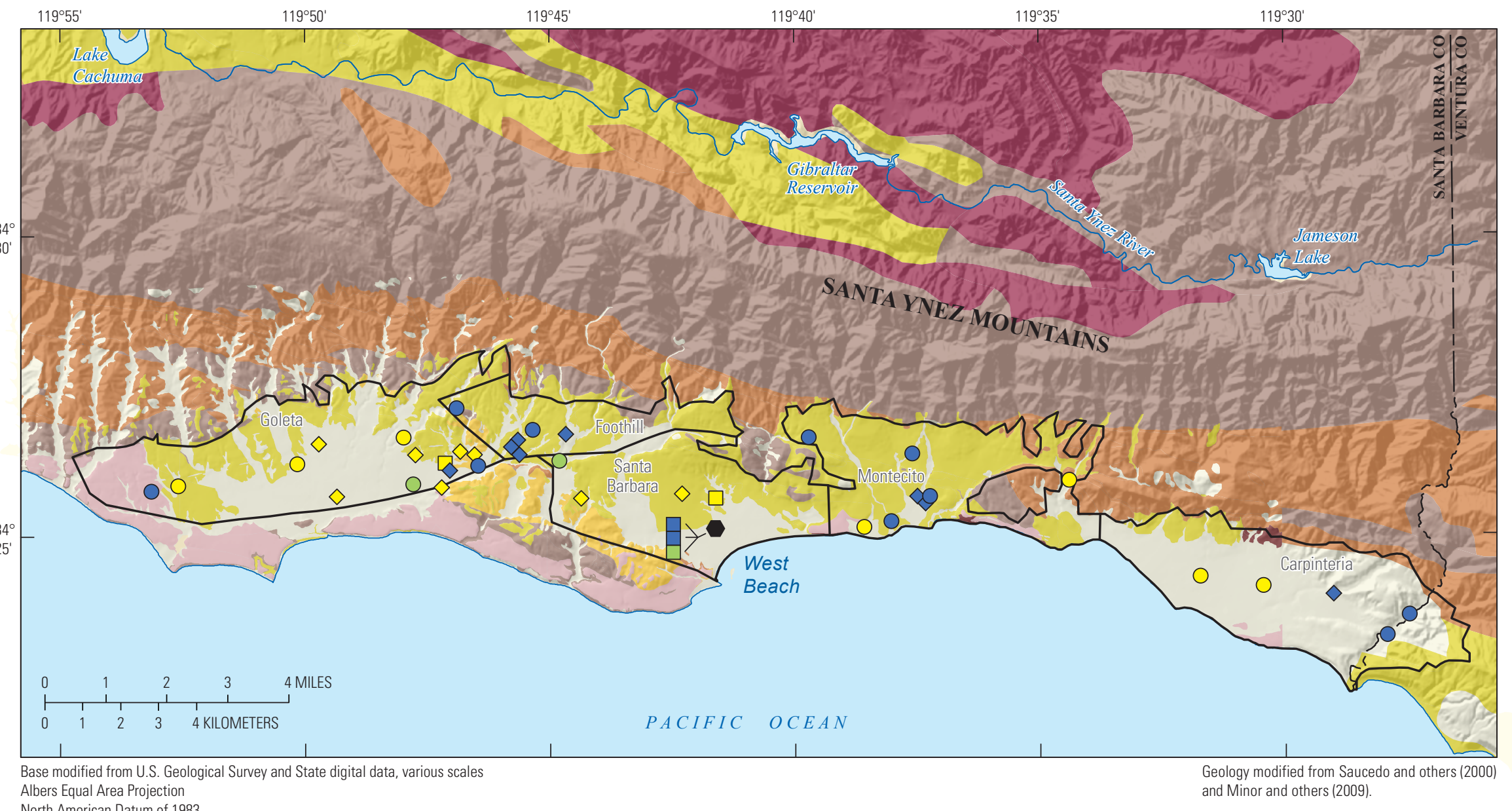

North American Datum of 1983

\section{EXPLANATION}

Geologic description

7) Older alluvial deposits (Pleistocene)

39. Santa Barbara Formation (Pleistocene)

Casitas Formation (Pleistocene)

Alluvial and surficial deposits

(Holocene and upper Pleistocene)

19) Marine-terrace deposits (upper Pleistocene)
Marine mudstone and shale (Miocene and some Pliocene)

Sandstone and mudstone in the shallower unit, with conglomerates in the lower unit (Oligocene)

39. Metamorphic marine sediment (Mesozoic)

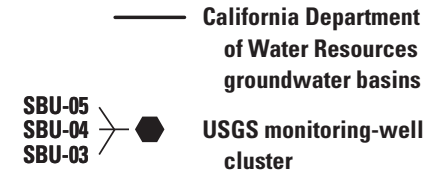

SBU-04 -03 and Minor and others (2009).

Manganese, in micrograms per liter

Relative- USGS grid and USGS understanding Other CDPH concentration

Low $(\leq 25)$

Moderate (>25 to 50 )

High $(>50)$

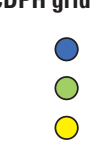

Figure 12. - Continued

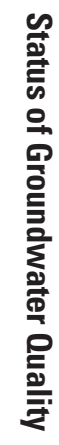




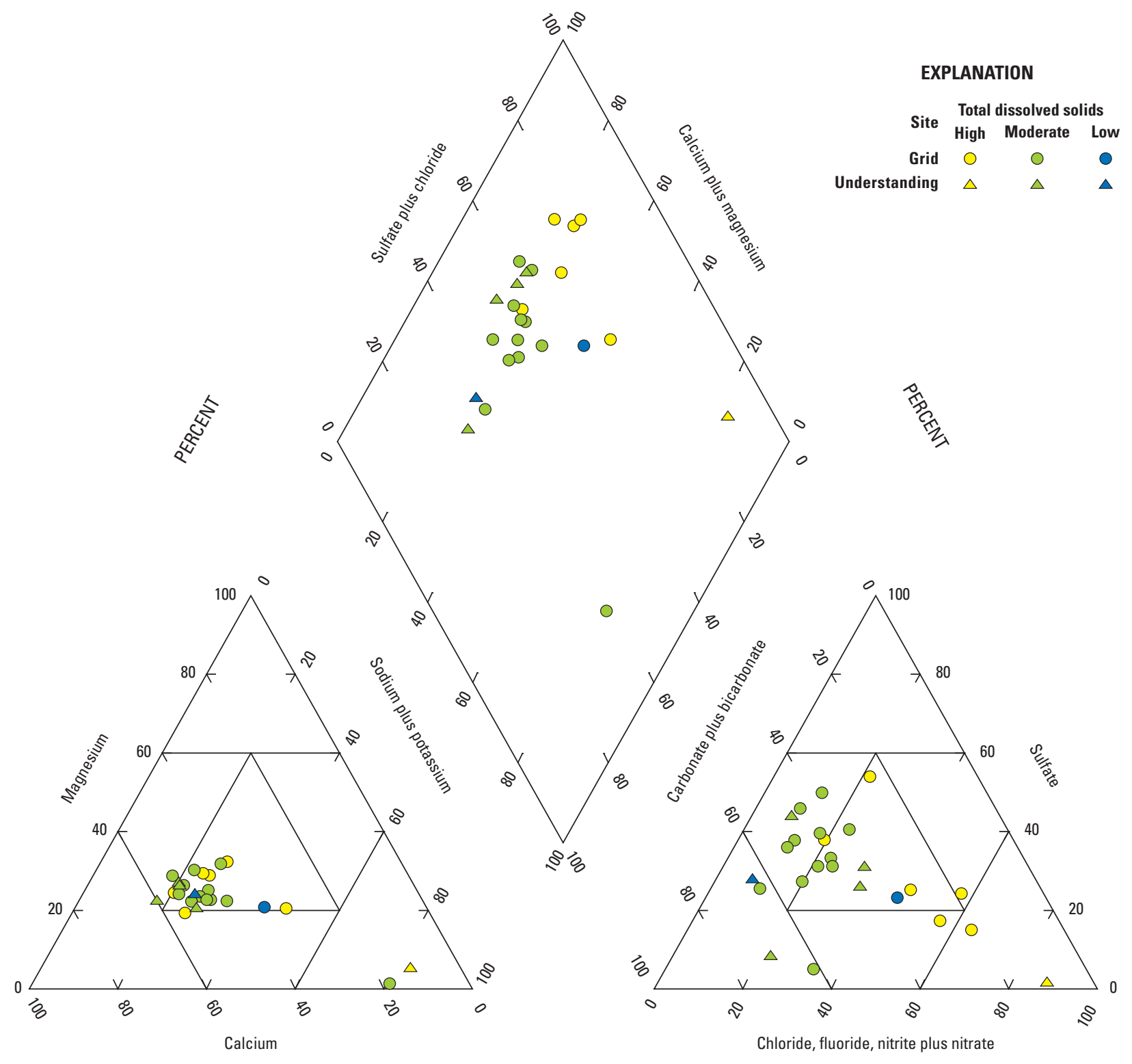

PERCENT

Figure 13. U.S. Geological Survey (USGS) grid and USGS understanding sites, grouped by total dissolved solids (TDS) concentrations, Santa Barbara study unit, 2011, California Groundwater Ambient Monitoring and Assessment (GAMA) Priority Basin Project. 


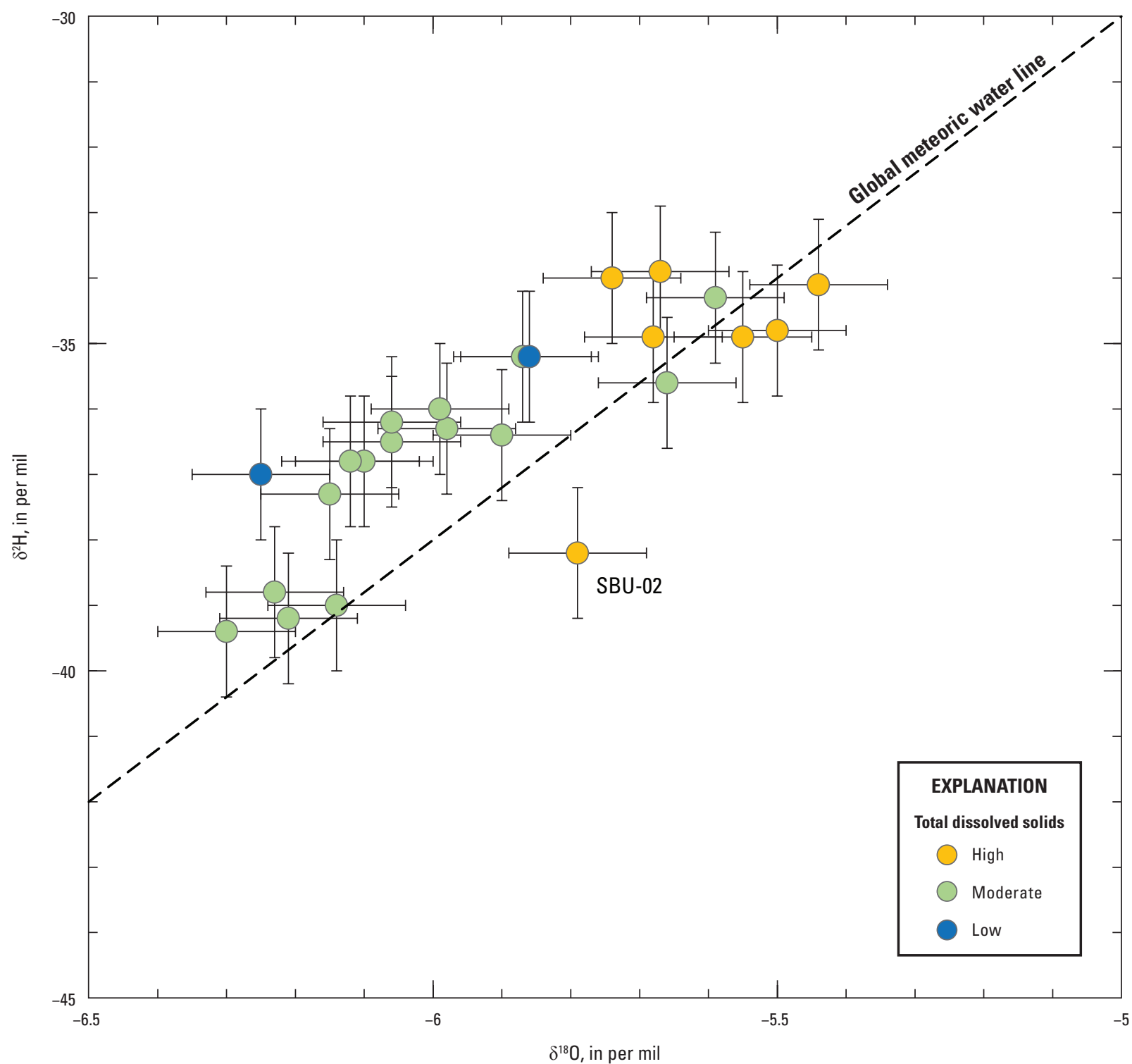

Figure 14. Stable isotope ratios of hydrogen and oxygen for U.S. Geological Survey (USGS) grid and USGS understanding sites, by groundwater total dissolved solids relative-concentration, Santa Barbara study unit, 2011, California Groundwater Ambient Monitoring and Assessment (GAMA) Priority Basin Project. 
In addition to several existing monitoring wells and public supply wells included in this study, two monitoring well clusters with a total of eight wells were drilled near the coast to monitor for early indications of saltwater intrusion. Six of the sites had groundwater with high TDS and moderate to high chloride concentrations and showed evidence of seawater intrusion (Martin, 1984). Groundwater from another shallow coastal monitoring well had high TDS and moderate chloride concentrations and showed evidence of mixing with groundwater from the deep zone.

As part of this assessment of current water-quality in the Santa Barbara primary aquifer system, TDS was present only at moderate relative-concentrations and chloride and sulfate were present at low relative-concentrations within the boundary of the Santa Barbara groundwater basin (figs. 12AC). These results indicated that groundwater currently used for public supply in the Santa Barbara groundwater basin has not been affected much by seawater intrusion, likely because of groundwater-management practices, including decreased municipal pumping and artificial recharge. A more intensive study, however, that samples more production wells than were available for this study, would be required to identify the presence and cause of high relative-concentrations of salinity indicators in small proportions of the basin.

\section{Iron and Manganese}

The redox indicators iron and manganese were present at high relative-concentrations in 37 percent of the Santa Barbara primary aquifer system and at moderate relativeconcentrations in 21 percent (table 7). Iron was present both at high and at moderate relative-concentrations in 16 percent of the primary aquifer system (table 6). Manganese was present at high relative-concentrations in 37 percent, and at moderate relative-concentrations in 11 percent, of the primary aquifer system. Most of the high relative-concentrations of iron and manganese were measured in water from the Goleta groundwater basin (figs. $12 D-E$ ). In addition to high iron and manganese, groundwater chemistry in the Goleta Basin had other characteristics typical of anoxic conditions, including low nitrate (fig. 11) and mostly moderate to high relative concentrations of sulfate (fig. 12B). Half of the sites where groundwater was classified as anoxic (iron and sulfate reducing) were in the Goleta Basin (fig. 7A), whereas other groundwater basins in the Santa Barbara study unit were characterized as a mix of oxic and anoxic (including reduction of nitrate and manganese) processes (table 2-3). The comparison between the groundwater basins is limited to the data available for each basin, however (for example, Santa Barbara groundwater basin has 8 sites, whereas the Goleta basin has 18 sites).

\section{Organic and Special-Interest Constituents}

Organic constituents (such as VOCs, pesticides, and pharmaceuticals), unlike inorganic constituents, usually have anthropogenic origins. VOCs are present in paints, solvents, fuels, fuel additives, refrigerants, fumigants, and disinfected water and are characterized by their tendency to evaporate. VOCs typically persist longer in groundwater than in surface water because groundwater is isolated from the atmosphere. Pesticides include herbicides, insecticides, and fungicides and are used to control weeds, insects, fungi, and other pests in agricultural and urban settings. Classes of organic constituents discussed in this section are VOCs - which were further divided into gasoline components, trihalomethanes (THMs), and solvents - and pesticides.

Special-interest constituents, similar to organic constituents, are usually anthropogenic in origin. Constituents of special interest analyzed in the Santa Barbara study unit were perchlorate and $N$-nitrosodimethylamine (NDMA). They were classified as special-interest constituents because, at the inception of the GAMA Priority Basin Project in 2003, they had recently been detected in water from public-supply wells in several areas of the State (California State Water Resources Control Board, 2014), and the CDPH was evaluating whether or not MCL-CAs should be established. An MCL-CA for perchlorate was established in 2007.

In the Santa Barbara study unit, 10 of the 218 organic constituents analyzed by USGS-GAMA were detected at grid sites (table 4). Of these 10 constituents, 9 had regulatory health-based benchmarks, and 1 had no established benchmarks. Organic constituents were not present at high relative-concentrations in the primary aquifer system (table 7; figs. 8, 15). Organic constituents with health-based benchmarks, as a group, were present at moderate relativeconcentrations in 11 percent of the primary aquifer system and at low relative-concentrations in 50 percent and were not detected in 39 percent of the primary aquifer system. Detections of VOCs were the sole contributor to moderate aquifer-scale proportion. Pesticides were present at low relative-concentrations or not detected. Pharmaceutical compounds were not detected in samples from the USGS grid or USGS understanding sites for the Santa Barbara study unit (Davis and others, 2013). Perchlorate was the only specialinterest constituent present in the primary aquifer system of the Santa Barbara study unit, and it was not detected at high relative-concentrations (fig. 15). 


\section{Volatile Organic Compounds}

In the Santa Barbara study unit, VOCs were present at moderate relative-concentrations in 11 percent of the primary aquifer system and at low relative-concentrations in 44 percent (table 7). Gasoline components were present at moderate relative-concentrations in 11 percent of the primary aquifer system, followed by solvents, which were present in 5.6 percent. Methyl tert-butyl ether (MTBE) and 1,2-dichloroethane (1,2-DCA) were detected at moderate relative-concentrations at one or more grid sites (table 6, fig. 15). Trihalomethanes, primarily chloroform, were the VOCs that were prevalent at low relative-concentrations (47 percent aquifer-scale proportion) in the primary aquifer system (table 7). One VOC without a benchmark was detected at less than 10 percent of the USGS grid sites.

\section{Gasoline Components}

MTBE, the only gasoline hydrocarbon or oxygenate detected in the Santa Barbara study unit, had the highest relative-concentration of the organic and special-interest constituents (figs. 15, 16). MTBE was detected at a frequency of 11 percent and was present in the central region of the study unit (fig. 17A), which is predominantly characterized by urban land use. The compound is an oxygen additive in gasoline, and since 2003, its use by refiners throughout California and the Nation has decreased in favor of alternatives such as ethanol (State of California, 2003; U.S. Environmental Protection Agency, 2013). The oxygenate is still one of the most frequently detected gasoline components in groundwater in California and the Nation (Zogorski and others, 2006; Landon and others, 2013).

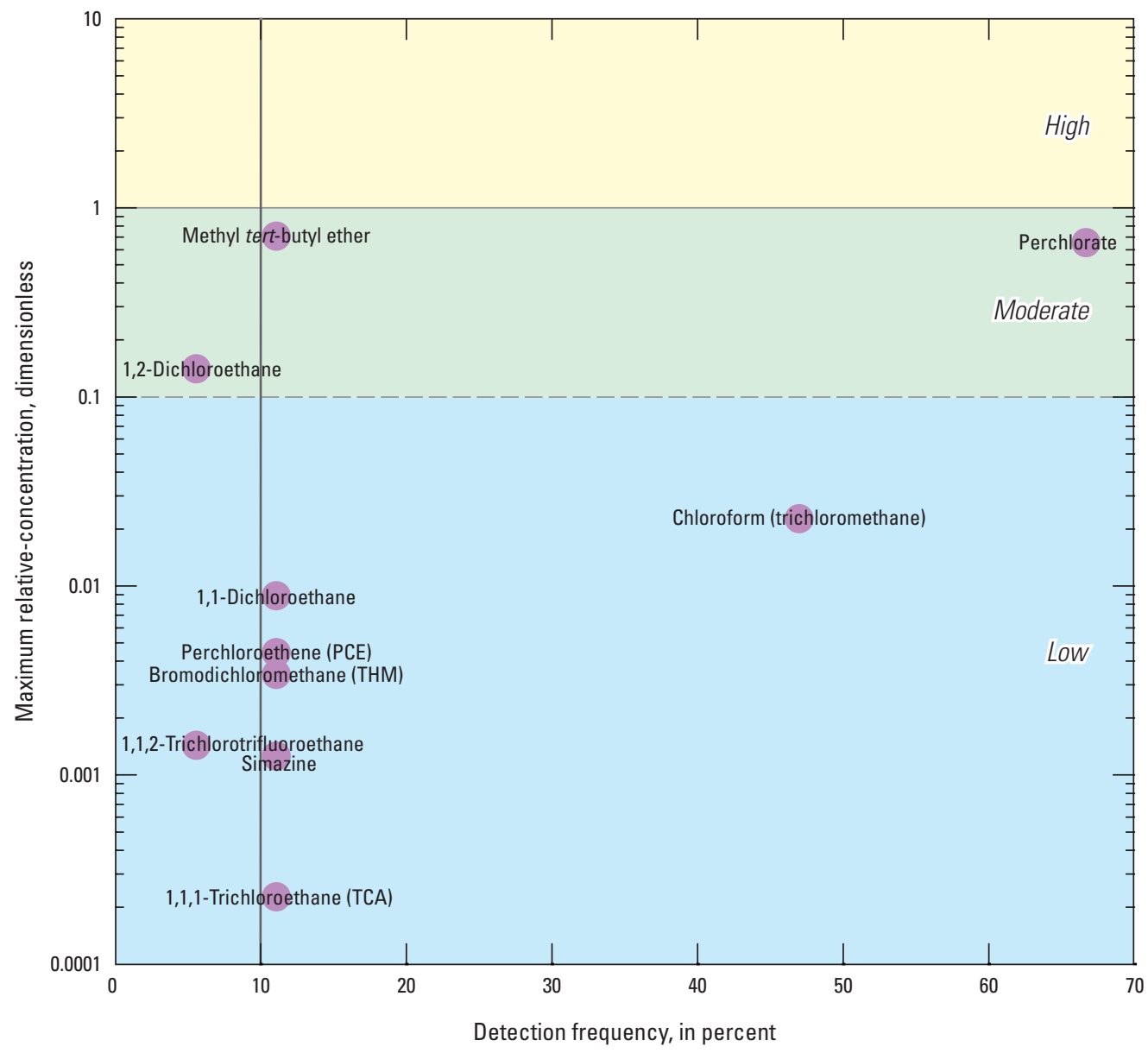

Figure 15. Detection frequencies and maximum relative-concentrations of organic and special-interest constituents detected at U.S. Geological Survey (USGS) grid sites, Santa Barbara study unit, 2011, California Groundwater Ambient Monitoring and Assessment (GAMA) Priority Basin Project. 


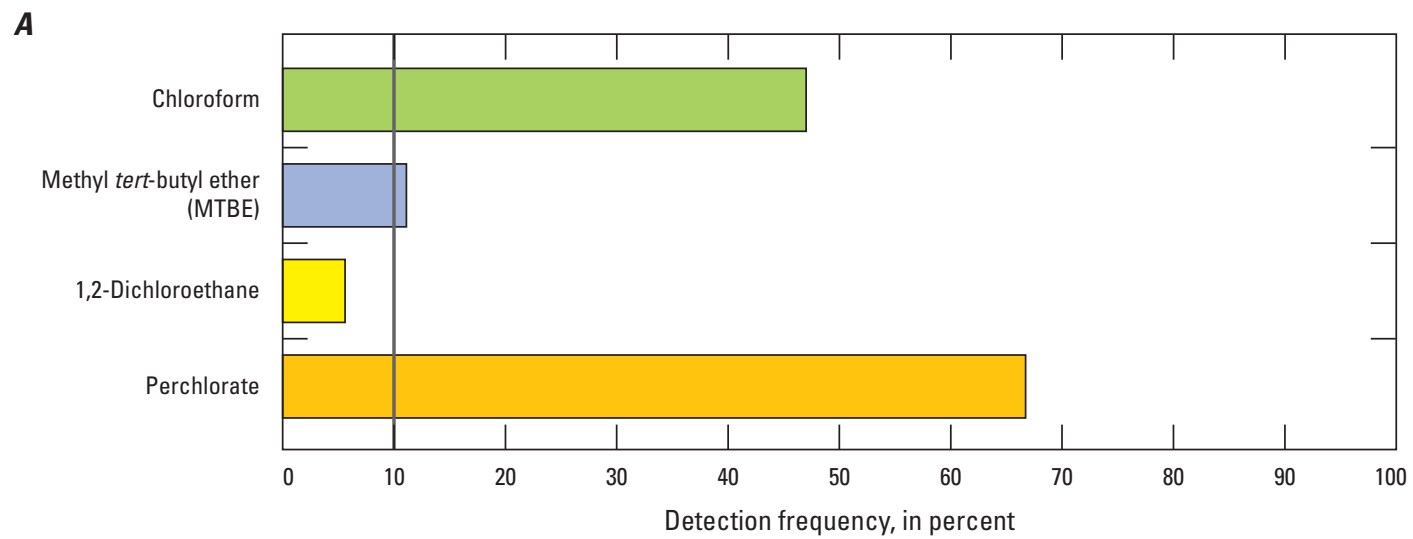

$\boldsymbol{B}$

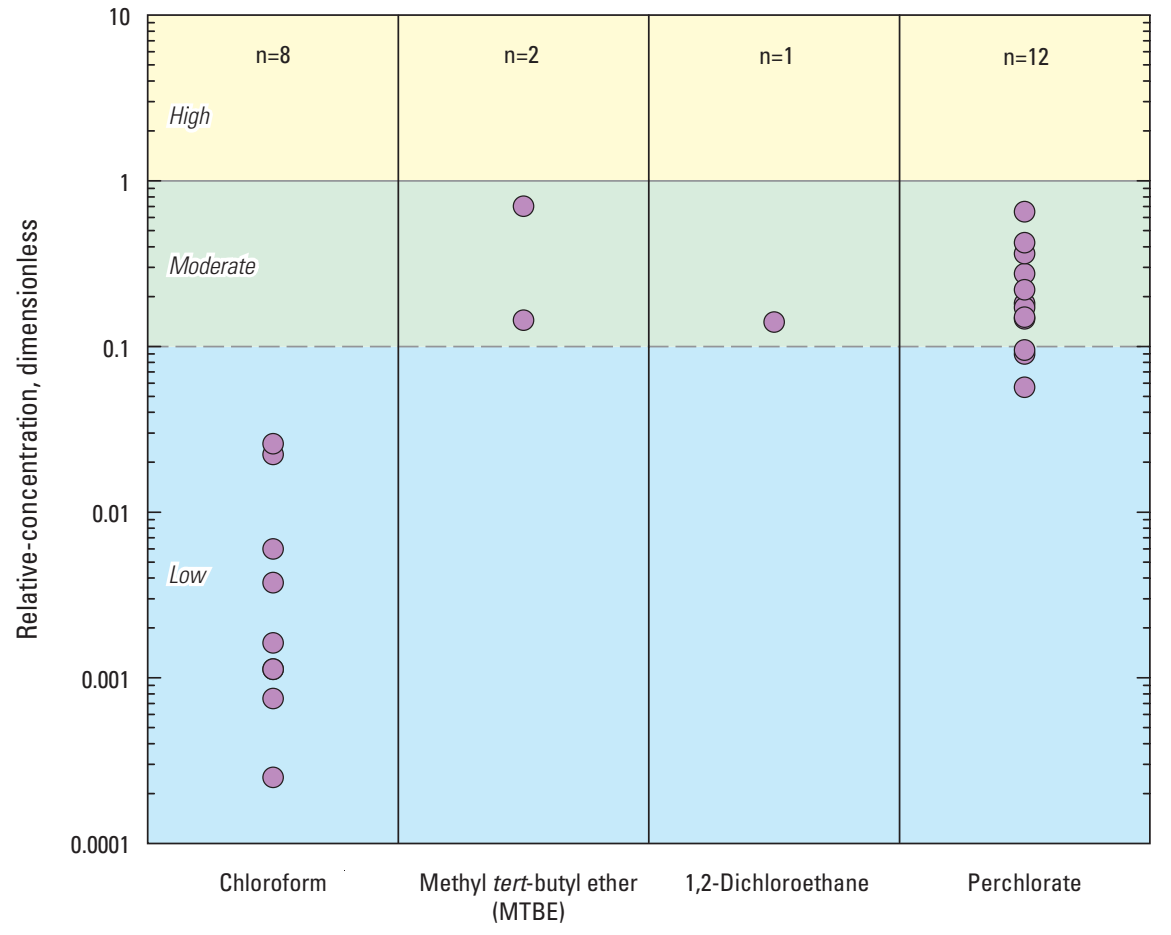

Figure 16. Groundwater data of selected organic and special-interest constituents at U.S. Geological Survey (USGS) grid sites, Santa Barbara study unit, 2011, California Groundwater Ambient Monitoring and Assessment (GAMA) Priority Basin Project: $A$, detection frequencies; and $B$, relative-concentrations. 


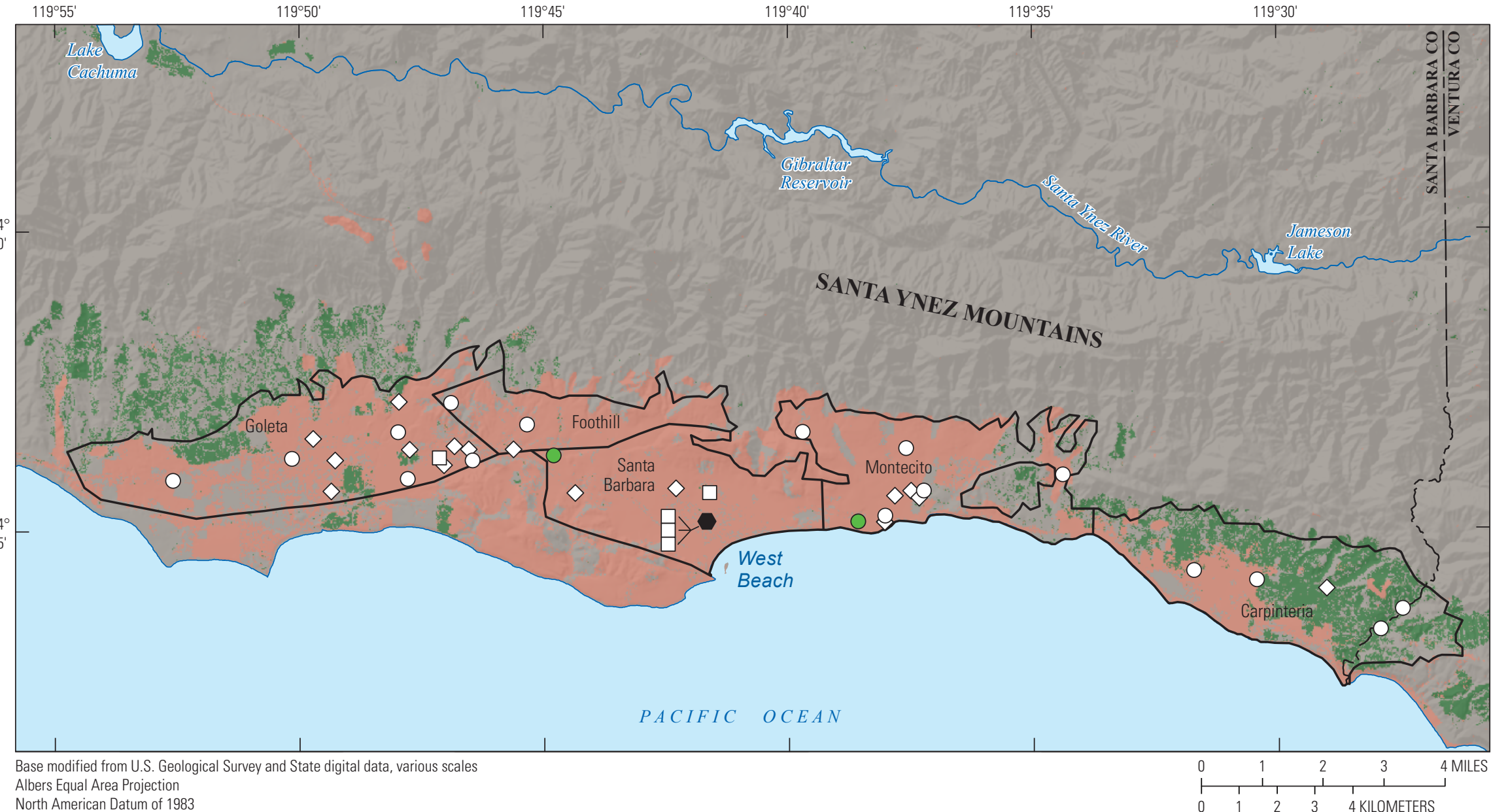

North American Datum of 1983

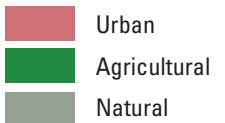

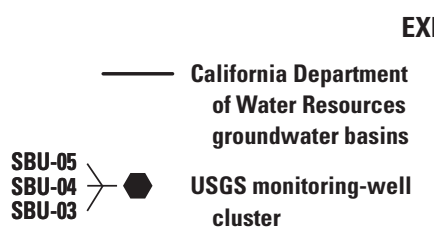

\section{EXPLANATION}

cluster

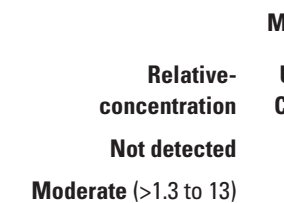

Methyl tert-butyl ether (MTBE), in micrograms per liter

USGS grid and USGS understanding Other CDPH

site sites

O

$\square$

$\diamond$

Figure 17. Relative-concentrations at U.S. Geological Survey (USGS) grid, USGS understanding, and California Department of Public Health (CDPH) sites, Santa Barbara study unit, 2011, California Groundwater Ambient Monitoring and Assessment (GAMA) Priority Basin Project, of $A$, MTBE; $B$, solvents; $C$, chloroform; $D$, simazine; and $E$, perchlorate. 


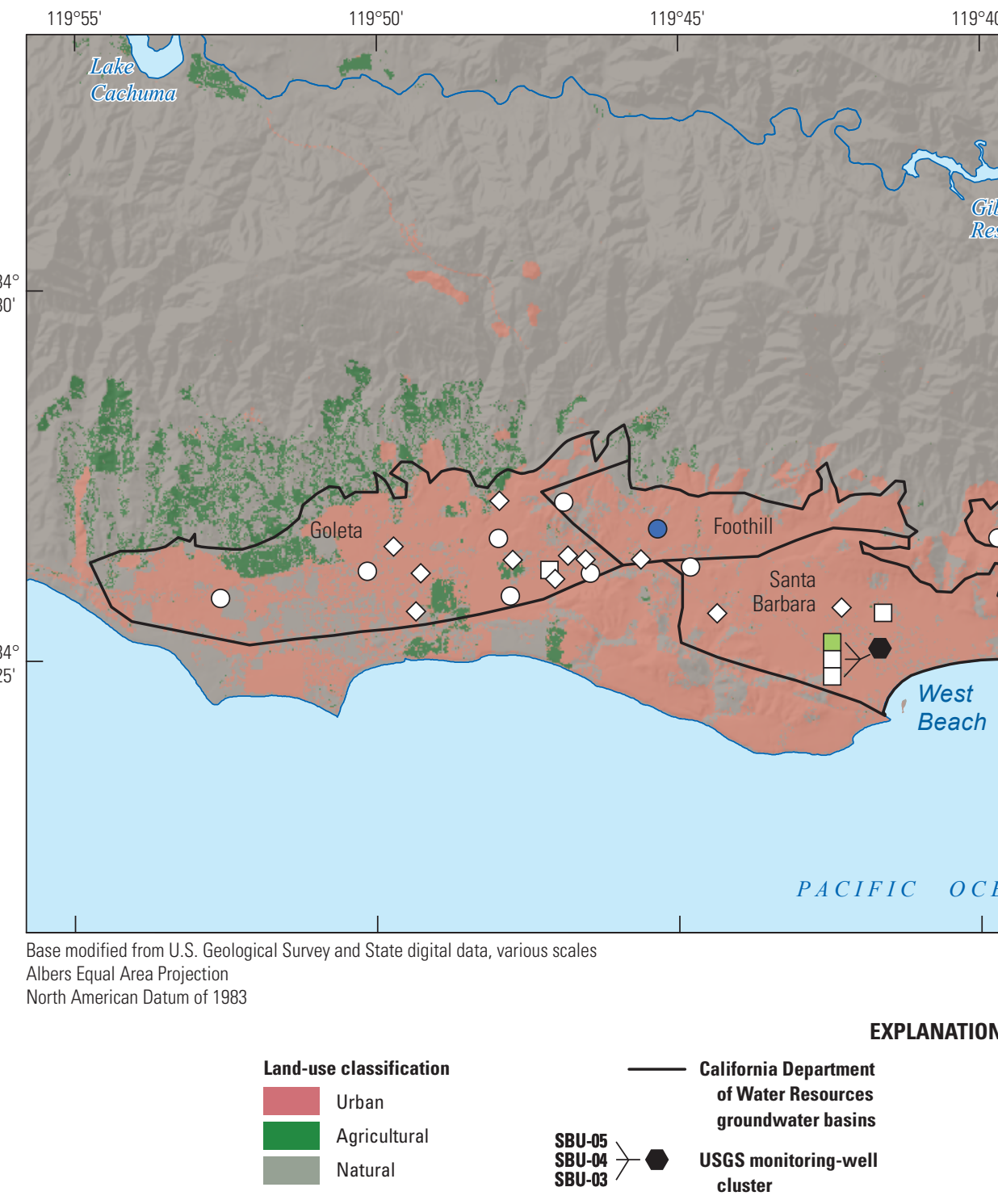

$19^{\circ} 40^{\prime}$

\section{SANTA YNEZ MOUNTAINS}
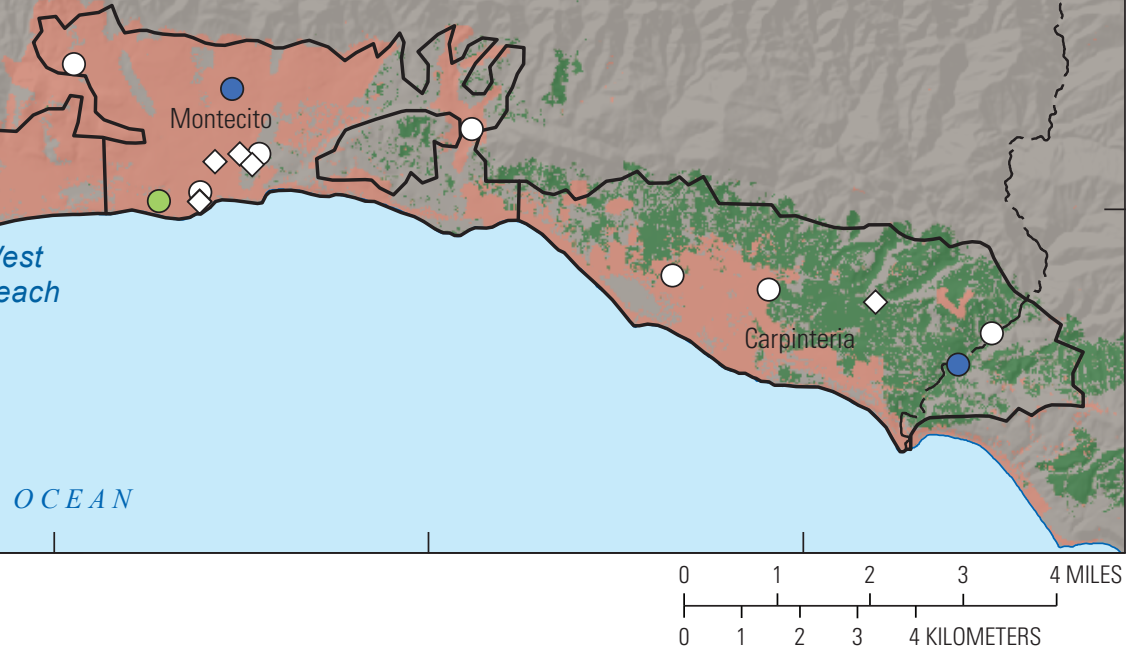

Figure 17. - Continued

\begin{tabular}{|c|c|c|c|}
\hline \multirow[b]{2}{*}{$\begin{array}{r}\text { Relative- } \\
\text { concentration }\end{array}$} & \multicolumn{3}{|c|}{ ore) } \\
\hline & $\begin{array}{l}\text { USGS grid and } \\
\text { CDPH grid sites }\end{array}$ & $\begin{array}{l}\text { USGS understanding } \\
\text { site }\end{array}$ & $\begin{array}{l}\text { Other CDPH } \\
\text { sites }\end{array}$ \\
\hline Not detected & 0 & $\square$ & $\diamond$ \\
\hline Low & 0 & & \\
\hline Moderate & 0 & $\square$ & \\
\hline
\end{tabular}




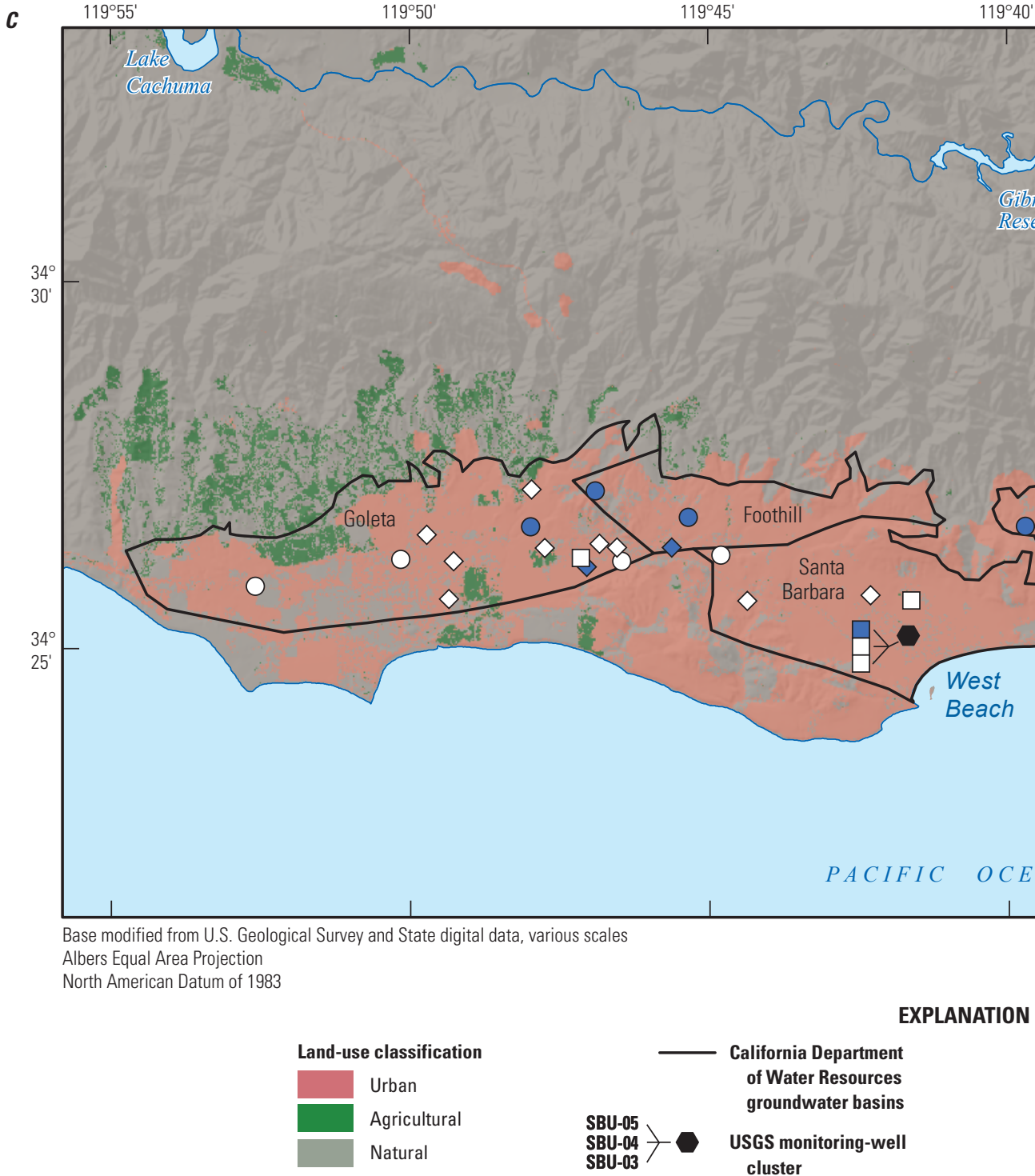

Figure 17. - Continued

$S B U-04$
$S B U-03$ cluster

\begin{tabular}{ll}
$119^{\circ} 35^{\circ}$ \\
\hline
\end{tabular}

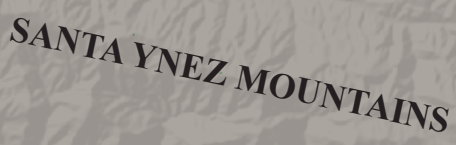

Srover Lake

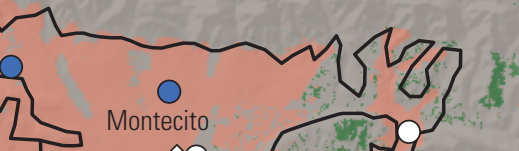

$\Delta \infty \curvearrowright$
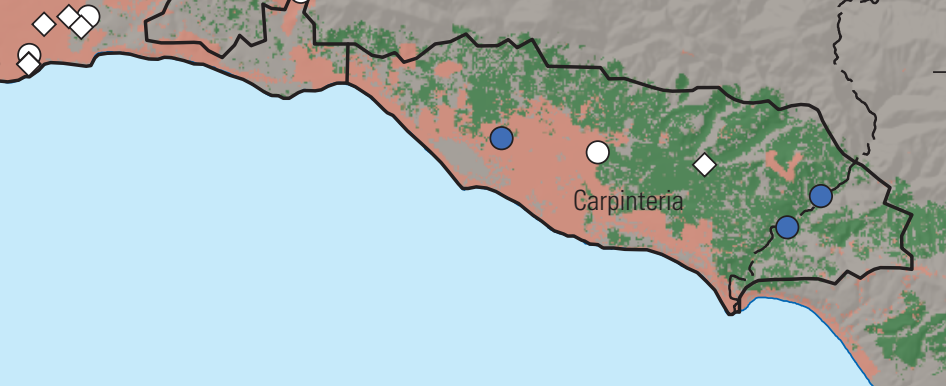


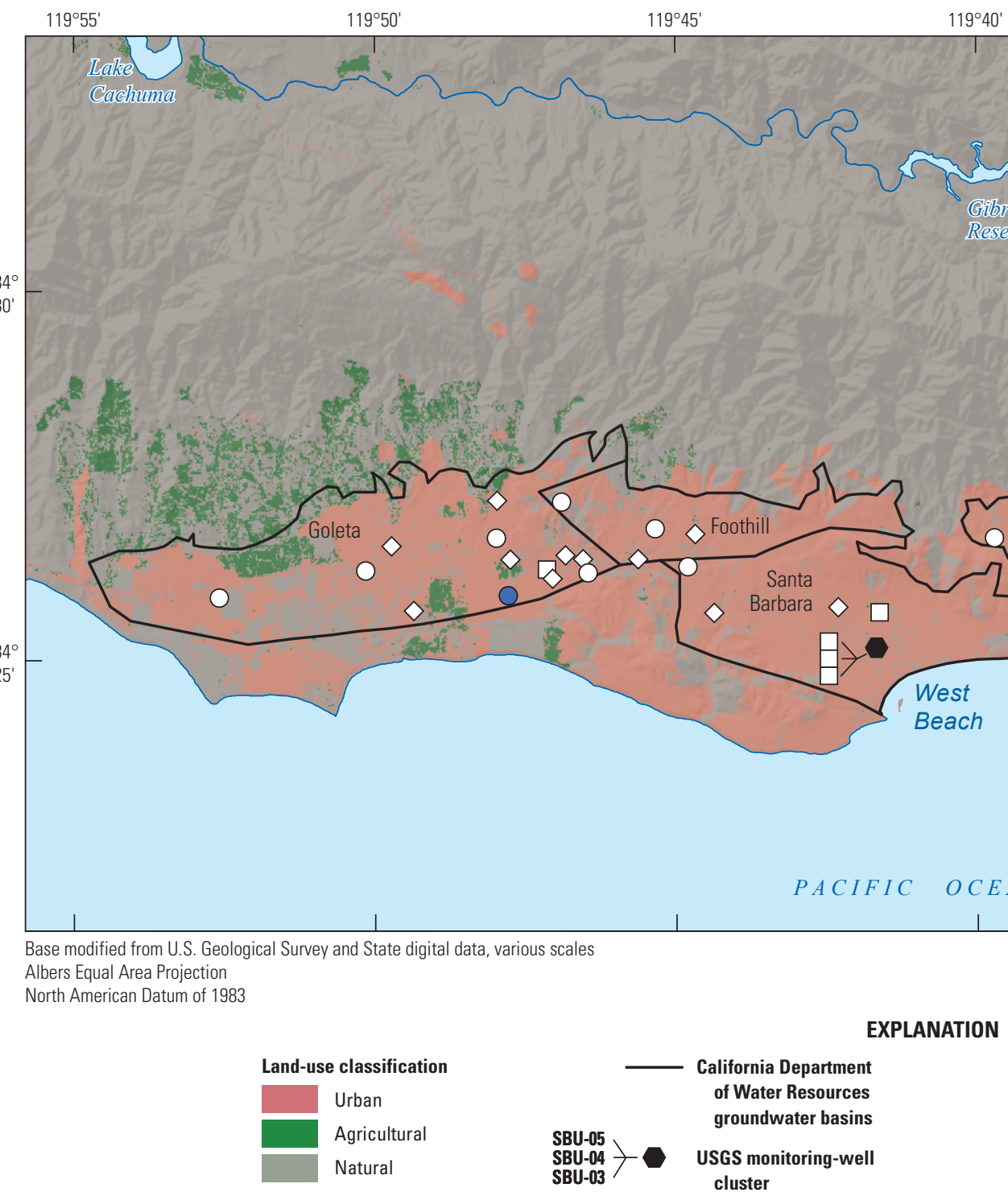

$119^{\circ} 35^{\circ}$

34

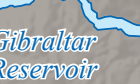

SANTA YNEZ MOUNTAINS

Survectake

$$
\text { - }
$$

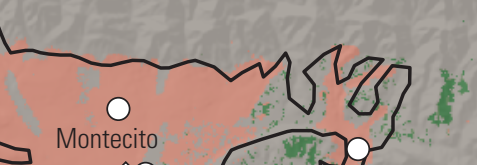

$\Delta \diamond$

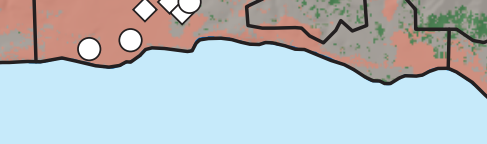

each

cluster

Simazine, in micrograms per liter

Relative- USGS grid and USGS understanding Other CDPH concentration CDPH grid sites site sites

Not detected

Low $(\leq 0.4)$ $\bigcirc$

$\square$ $\diamond$

Figure 17. - Continued 


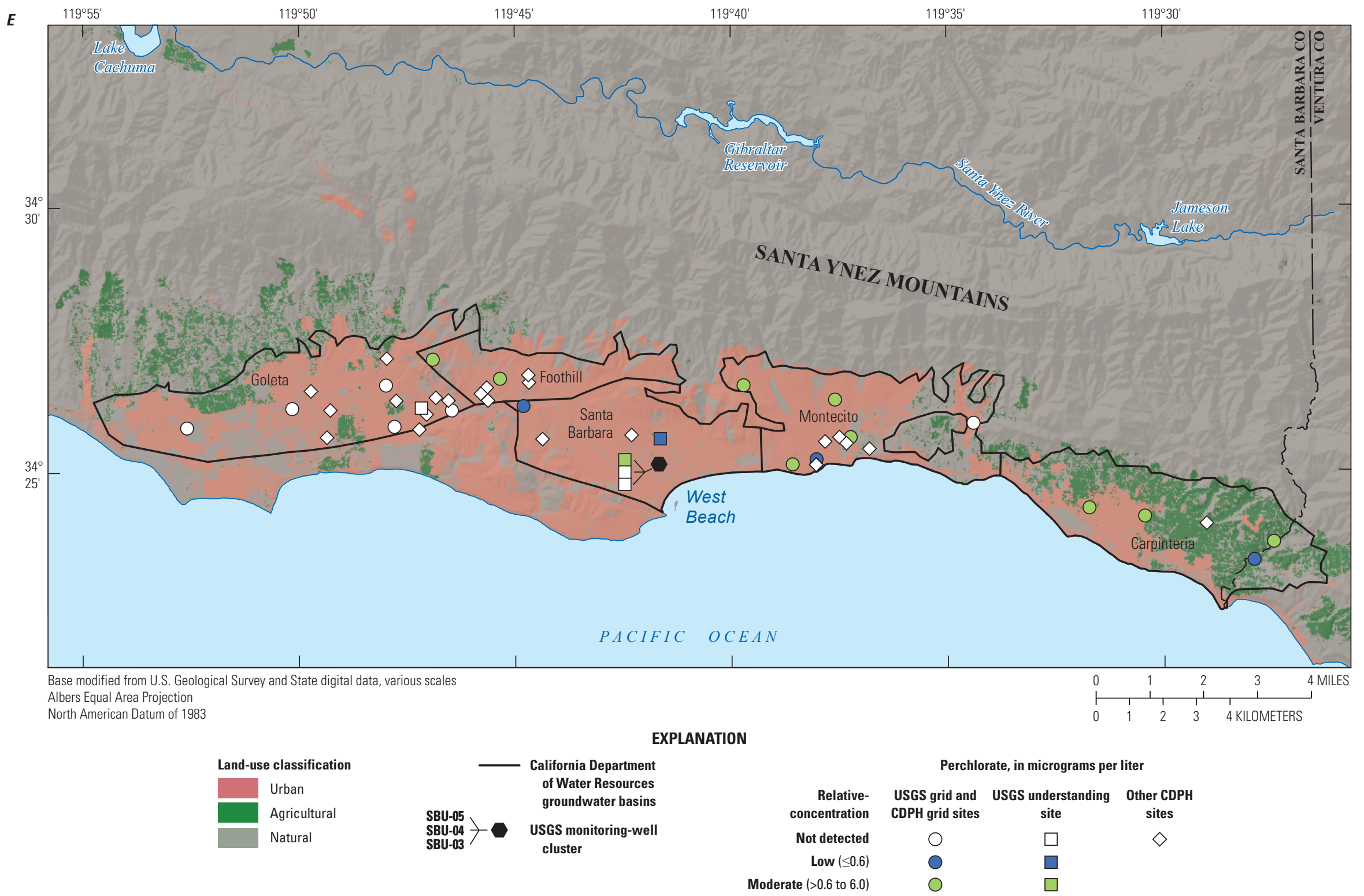

Figure 17. - Continued

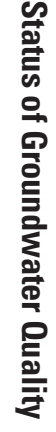




\section{Solvents}

Solvents were present at moderate relativeconcentrations in 5.6 percent of the primary aquifer system and at low relative-concentrations in 17 percent (table 7). 1,2-Dichloroethane was present at moderate relativeconcentrations in 5.6 percent of the primary aquifer system. Perchloroethene (PCE) was detected at low concentrations in 11 percent of the samples collected from USGS grid sites (fig. 15). Perchloroethene was present at moderate relative-concentrations in 1.4 percent of the primary aquifer system (spatially weighted; table 6); the moderate relativeconcentration of PCE was measured in one sample from a USGS understanding site, which also had a moderate relativeconcentration of the solvent tetrachloromethane. Other solvents for which detection frequencies were greater than 10 percent, but were detected at low relative-concentrations, were 1,1,1-trichloroethane and 1,1-dichloroethane. Solvents were detected in water from at least one USGS grid well in each groundwater basin, except the Goleta Basin (fig. 17B). Solvents are used for various industrial, commercial, and domestic purposes. PCE is primarily used for dry cleaning of fabrics and degreasing metal parts and is an ingredient in a wide range of products, including paint removers, polishes, printing inks, lubricants, and adhesives.

\section{Trihalomethanes}

The THMs detected in the Santa Barbara study unit were chloroform and bromodichloromethane (Davis and others, 2013). Low concentrations of chloroform and bromodichloromethane in water were detected at 47 percent and 11 percent, respectively, of the USGS grid sites (fig. 15). Of the 11 grid sites where VOCs were detected in the groundwater, 8 had detections of chloroform; these grid sites were spread throughout the study unit (fig. 17C). The presence of THMs in groundwater has been attributed to the reaction of chlorine with organic matter during the chlorination of drinking water. In a study by the USGS National Water Quality Assessment (NAWQA) Program, chloroform was the most frequently detected VOC in aquifers across the nation, and bromodichloromethane was the second most frequently detected THM (Zogorski and others, 2006). Recently, the Cater Treatment Plant, where the majority of water that supplies Santa Barbara and local water districts is treated, switched from chlorine to ozone in the initial step of water treatment (City of Santa Barbara, 2013).

\section{Pesticides}

Pesticides, as a class, were present only at low relativeconcentrations in the Santa Barbara study unit. Simazine was the sole contributor to the low aquifer-scale proportions for pesticides (11 percent; fig. 15; tables 6, 7). Simazine was measured at one of the lowest relative-concentrations of the detected organic and special-interest constituents and was detected in groundwater near areas of agricultural land use in the study unit (fig. 17D). Simazine is a herbicide used in agricultural applications, particularly for orange groves and vineyards in California (Kegley and others, 2014), but is commonly used in urban areas as well. Simazine is among the most frequently detected herbicides in groundwater and streams both in agricultural and urban areas throughout the Nation (Gilliom and others, 2006).

\section{Perchlorate}

There both are natural and anthropogenic potential sources of perchlorate to groundwater. Perchlorate is formed naturally in the atmosphere, and very low concentrations are found in precipitation. Anthropogenic sources include solid rocket fuel, explosives, safety flares, Chilean nitrate fertilizer applied extensively in the early to mid-1900s, and remobilization of perchlorate salts that accumulate in the unsaturated zone. Additionally, perchlorate is a degradation product of hypochlorite solutions that are widely used for drinking-water disinfection. When concentrations are greater than 1 microgram per liter, there is a high probability that anthropogenic sources have contributed perchlorate to groundwater (Fram and Belitz, 2011).

Perchlorate was present at moderate relativeconcentrations in 50 percent of the primary aquifer system and at low concentrations in 17 percent (table 7). The gridbased moderate aquifer-scale proportion was greater than the spatially weighted moderate aquifer-scale proportion for perchlorate (31 percent; table 6), because the reporting limit for USGS-GAMA data was much lower than that for data in the CDPH database (table 3). The CDPH database reporting limit was $4 \mu \mathrm{g} / \mathrm{L}$, corresponding to a relative-concentration of 0.67 ; moderate relative-concentrations between 0.10 and 0.67 would have been reported as non-detections, lowering the spatially weighted aquifer-scale proportion. The USGSGAMA reporting limit is $0.10 \mu \mathrm{g} / \mathrm{L}$, corresponding to a relative-concentration of less than 0.02 . The detection frequency of perchlorate was almost 70 percent (fig. 16), and, similar to solvents, perchlorate was detected at sites throughout the study unit, except in the Goleta groundwater basin (fig. 17E). 


\section{Summary}

Groundwater quality in the $48 \mathrm{mi}^{2}$ Santa Barbara study unit was investigated as part of the Priority Basin Project of the California Groundwater Ambient Monitoring and Assessment (GAMA) Program. The Santa Barbara study unit was designed to provide a statistically unbiased, spatially distributed characterization of untreated groundwater quality in the primary aquifer system used for public and community drinking-water supplies. The assessment is based on water-quality and ancillary data collected in 2011 by the U.S. Geological Survey (USGS) from 23 sites and on waterquality data from the California Department of Public Health $(\mathrm{CDPH})$ database.

This status assessment characterized the current quality of groundwater resources in the primary aquifer system of the Santa Barbara study unit before it is treated and delivered to consumers by water purveyors. Data used included samples analyzed for anthropogenic constituents, such as volatile organic compounds (VOCs), pesticides, pharmaceuticals, and special-interest constituents, as wells as naturally present inorganic constituents, such as major and minor ions and trace elements. Relative-concentrations (sample concentrations divided by benchmark concentrations) were used for evaluating groundwater quality for detected constituents that have federal and (or) California regulatory or non-regulatory benchmarks for drinking-water quality. Constituents classified as "high" have relative-concentrations greater than 1.0. The relative-concentration threshold for classifying inorganic constituents as "moderate" was 0.5 , whereas, for organic constituents, it was 0.1 .

Aquifer-scale proportion was used as the primary metric for assessing regional-scale groundwater quality. High aquiferscale proportion is defined as the areal percentage of the primary aquifer system with a relative-concentration greater than 1.0 for a particular constituent or class of constituents. Moderate and low aquifer-scale proportions are defined as the percentage of the primary aquifer system with moderate and low relative-concentrations, respectively. Grid-based and spatially weighted statistical approaches were used to assess aquifer-scale proportions, and results were comparable (within 90-percent confidence intervals) for the two methods in the Santa Barbara study unit.

Inorganic constituents were more prevalent and generally measured at higher relative-concentrations than organic constituents. For inorganic constituents with human-health benchmarks, relative-concentrations were high in 5.3 percent of the primary aquifer system and moderate in 32 percent. Boron and fluoride were the primary inorganic constituents with human-health benchmarks present at high relativeconcentrations. For inorganic constituents with aesthetic-based benchmarks (CDPH secondary maximum contaminant levels), relative-concentrations were high in 58 percent of the primary aquifer system and moderate in 37 percent. Iron, manganese, sulfate, and total dissolved solids (TDS) were the inorganic constituents with aesthetic-based benchmarks present at high relative-concentrations.

In contrast to inorganic constituents, organic constituents with human-health benchmarks were not detected at high relative-concentrations in the primary aquifer system in the Santa Barbara study unit. Of the 218 organic constituents analyzed, 10 were detected -9 had human-health benchmarks. Relative-concentrations of organic constituents were moderate in 11 percent of the primary aquifer system. The VOCs present at moderate relative-concentrations included MTBE (11 percent), 1,2-dichloroethane (5.6 percent), and PCE (1.4 percent, spatially weighted). All pesticides were present at low relative-concentrations or not detected. The specialinterest constituent perchlorate was present at moderate relative-concentrations in 50 percent of the primary aquifer system and at low relative-concentrations in 17 percent. Pharmaceutical compounds and NDMA were not detected at concentrations greater than or equal to method detection limits in the Santa Barbara study unit.

\section{References Cited}

Belitz, Kenneth, Dubrovsky, N.M., Burow, Karen, Jurgens, B.C., and Johnson, Tyler, 2003, Framework for a ground-water quality monitoring and assessment program for California: U.S. Geological Survey WaterResources Investigations Report 2003-4166, 78 p., https://pubs.er.usgs.gov/publication/wri034166.

Belitz, Kenneth, Jurgens, Bryant, Landon, M.K., Fram, M.S., and Johnson, Tyler, 2010, Estimation of aquifer scale proportion using equal area grids-Assessment of regional scale groundwater quality: Water Resources Research, v. 46, no. 11, http://dx.doi.org/10.1029/2010WR009321.

Brown, L.D., Cai, T.T., and DasGupta, Anirban, 2001, Interval estimation for a binomial proportion: Statistical Science, v. 16, no. 2, p. 101-117, http://www.jstor.org/stable/2676784.

Burow, K.R., Shelton, J.L., and Dubrovsky, N.M., 2008, Regional nitrate and pesticide trends in ground water in the eastern San Joaquin Valley, California: Journal of Environmental Quality, v. 37, no. 5 Supplement, p. S-249-S-263, http://dx.doi.org/10.2134/jeq2007.0061.

Burton, C.A., Shelton, J.L., and Belitz, Kenneth, 2012, Status and understanding of groundwater quality in the two southern San Joaquin Valley study units, 2005-2006California GAMA Priority Basin Project: U.S. Geological Survey Scientific Investigations Report 2011-5218, 106 p., https://pubs.er.usgs.gov/publication/sir20115218. 
California Department of Water Resources, 2003, California's groundwater update 2003: California Department of Water Resources Bulletin 118, 246 p., accessed May 27, 2014, at http://www.water.ca.gov/groundwater/bulletin118/ update_2003.cfm.

California Department of Water Resources, 2004a, California's groundwater-Carpinteria Groundwater Basin: California Department of Water Resources Bulletin 118, accessed May 27, 2014, at http://www.water.ca.gov/pubs/ groundwater/bulletin_118/basindescriptions/3-18.pdf.

California Department of Water Resources, 2004b, California's groundwater-Foothill Groundwater Basin: California Department of Water Resources Bulletin 118, accessed May 27, 2014, at http://www.water.ca.gov/pubs/ groundwater/bulletin_118/basindescriptions/3-53.pdf.

California Department of Water Resources, 2004c, California's groundwater-Goleta Groundwater Basin: California Department of Water Resources Bulletin 118, accessed May 27, 2014, at http://www.water.ca.gov/pubs/ groundwater/bulletin_118/basindescriptions/3-16.pdf.

California Department of Water Resources, 2004d, California's groundwater-Montecito Groundwater Basin: California Department of Water Resources Bulletin 118, accessed May 27, 2014, at http://www.water.ca.gov/pubs/ groundwater/bulletin_118/basindescriptions/3-49.pdf.

California Department of Water Resources, 2004e, California's groundwater-Santa Barbara Groundwater Basin: California Department of Water Resources Bulletin 118, accessed May 27, 2014, at http://www.water.ca.gov/pubs/ groundwater/bulletin_118/basindescriptions/3-17.pdf.

California Environmental Protection Agency, 2001, Geographic Environmental Information Management System GeoTracker (GEIMS) Leaking Underground Fuel/ Storage Tank database (LUFT) [digital data]: Sacramento, Calif., California Environmental Protection Agency, State Water Resources Control Board, Division of Water Quality. Data available online at http://geotracker.waterboards. ca.gov/data_download.asp.

California State Water Resources Control Board, 2003, A comprehensive groundwater quality monitoring program for California: Assembly Bill 599 Report to the Governor and Legislature, March 2003, 100 p., http://www.waterboards. ca.gov/gama/docs/final_ab_599_rpt_to_legis_7_31_03.pdf.

California State Water Resources Control Board, 2014, Emerging Contaminants: California State Water Resources Control Board website, accessed May 27, 2014, at http://www.waterboards.ca.gov/drinking_water/certlic/ drinkingwater/EmergingContaminants.shtml.
California State Water Resources Control Board, 2016a, California Drinking Water-Related Laws: California State Water Resources Control Board website, accessed September 12, 2016, at http://www.waterboards.ca.gov/ drinking_water/certlic/drinkingwater/Lawbook.shtml.

California State Water Resources Control Board, 2016b, Drinking water notification levels: California State Water Resources Control Board website, accessed September 12, 2016, at http://www.waterboards.ca.gov/drinking_water/ certlic/drinkingwater/NotificationLevels.shtml.

Centers for Disease Control and Prevention, 2001, Recommendations for using fluoride to prevent and control dental caries in the United States: Morbidity and Mortality Weekly Report, August 17, 2001, v. 40, no. RR-14, 42 p., http://www.cdc.gov/mmwr/PDF/rr/rr5014.pdf.

City of Santa Barbara, 2013, City of Santa Barbara Annual Water Quality Report_-June 2013, accessed May 20, 2014, at http://civicaweb.santabarbaraca.gov/gov/depts/pw/ resources/rates/newsletters.asp.

City of Santa Barbara, 2014, Water Sources, accessed May 20, 2014, at http://www.santabarbaraca.gov/gov/depts/pw/ resources/system/sources/default.asp.

Coplen, T.B., Hopple, J.A., Bohlke, J.K., Peiser, H.S., Rieder, S.E., Krouse, H.R., Rosman, K.J.R., Ding, T., Vocke, R.D., Jr., Revesz, K.M., Lamberty, A., Taylor, P., and DeBierve, P., 2002, Compilation of minimum and maximum isotope ratios of selected elements in naturally occurring terrestrial materials and reagents: U.S. Geological Survey Water-Resources Investigations Report 2001-4222, 98 p., https://pubs.er.usgs.gov/publication/wri014222.

Craig, Harmon, 1961, Isotopic variations in meteoric waters: Science, v. 133, no. 3465, p. 1702-1703, http://www.jstor.org/stable/1708089.

Davis, T.A., Kulongoski, J.T., and Belitz, Kenneth, 2013, Groundwater-quality data in Santa Barbara study unit, 2011-Results from the California GAMA Program: U.S. Geological Survey Data Series 742, 72 p., https://pubs.er.usgs.gov/publication/ds742.

Fram, M.S., and Belitz, Kenneth, 2011, Probability of detecting perchlorate under natural conditions in deep groundwater in California and the southwestern United States: Environmental Science and Technology, v. 45, no. 4, p. 1271-1277, http://dx.doi.org/10.1021/es103103p.

Fram, M.S., and Belitz, Kenneth, 2012, Status and understanding of groundwater quality in the TahoeMartis, Central Sierra, and Southern Sierra study units, 2006-2007-California GAMA Priority Basin Project: U.S. Geological Survey Scientific Investigations Report 2011-5216, 222 p., https://pubs.er.usgs.gov/publication/sir20115216. 
Freckleton, J.R., Martin, Peter, and Nishikawa, Tracy, 1998, Geohydrology of Storage Unit III and a combined flow model of the Santa Barbara and foothill ground-water basins, Santa Barbara County, California: U.S. Geological Survey Water-Resources Investigations Report 97-4121, 80 p., https://pubs.er.usgs.gov/publication/wri974121.

Gilliom, R.J., Barbash, J.E., Crawford, C.G., Hamilton, P.A., Martin, J.D., Nakagaki, Naomi, Nowell, L.H., Scott, J.C., Stackelberg, P.E., Thelin, G.P., and Wolock, D.M., 2006, The quality of our nation's waters-Pesticides in the nation's streams and ground water, 1992-2001: U.S. Geological Survey Circular 1291, 173 p., https://pubs.er.usgs.gov/publication/cir1291.

Hem, J.D., 1970, Study and interpretation of the chemical characteristics of natural water ( $2 \mathrm{~d}$ ed.): U.S. Geological Survey Water Supply Paper 1473, 363 p., https://pubs.er.usgs.gov/publication/wsp1473.

Hem, J.D., 1985, Study and interpretation of chemical characteristics of natural waters ( $3 \mathrm{~d}$ ed.): U.S. Geological Survey Water Supply Paper 2254, 263 p., https://pubs.er.usgs.gov/publication/wsp2254.

Isaaks, E.H., and Srivastava, R.M., 1989, Applied geostatistics: New York, Oxford University Press, 511 p.

Izbicki, J.A., Swarzenski, P.W., Reich, C.D., Rollins, Carole, and Holden, P.A., 2009, Sources of fecal indicator bacteria in urban streams and ocean beaches, Santa Barbara, California: Annals of Environmental Science, v. 3, p. 139178, accessed March 27, 2013, https://walrus.wr.usgs.gov/ reports/reprints/Izbicki_AES3.pdf.

Johnson, T.D., and Belitz, Kenneth, 2009, Assigning land use to supply wells for the statistical characterization of regional groundwater quality - Correlating urban land use and VOC occurrence: Journal of Hydrology, v. 370, p. 100-108, http://ca.water.usgs.gov/projects/gama/pdfs/ Johnson_2009_1-s2.0-S0022169409001462-main.pdf.

Jurgens, B.C., McMahon, P.B., Chapelle, F.H., and Eberts, S.M., 2009, An Excel workbook for identifying redox processes in ground water: U.S. Geological Survey Open-File Report 2009-1004, 8 p., https://pubs.er.usgs.gov/publication/ofr20091004.

Kegley, S.E., Hill, B.R., Orme, Stephan, Choi, A. H., 2014, PAN Pesticide Database, Pesticide Action Network, accessed July 21, 2014, at http://www.pesticideinfo.org.

Kendall, Carol, 1998, Tracing nitrogen sources and cycling in catchments, Chapter 16 in Kendall, Carol, and McDonnell, J.J., eds., Isotope tracers in catchment hydrology: Amsterdam, Elsevier Science, p. 519-576, http:// wwwrcamnl.wr.usgs.gov/isoig/isopubs/itchch16.html.
Klein, Cornelis, and Hurlbut, C.S., Jr., 1993, Manual of mineralogy (after James D. Dana), 21st ed.: New York, John Wiley and Sons, $681 \mathrm{p}$.

Kulongoski, J.T., and Belitz, Kenneth, 2004, Groundwater Ambient Monitoring and Assessment Program: U.S. Geological Survey Fact Sheet 2004-3088, 2 p., https://pubs.er.usgs.gov/publication/fs20043088.

Landon, M.K., Burton, C.A., Davis, T.A., Belitz, Kenneth, and Johnson, T.D., 2013, Statistical evaluation of variables affecting occurrence of hydrocarbons in aquifers used for public supply, California: Journal of the American Water Resources Association, v. 50, no. 1, p. 179-195, http://dx.doi.org/10.1111/jawr.12129.

Martin, Peter, 1984, Ground-water monitoring at Santa Barbara, California; Phase 2, Effects of pumping on water levels and on water quality in the Santa Barbara ground-water basin: U.S. Geological Survey Water Supply Paper 2197, 31 p., https://pubs.er.usgs.gov/publication/wsp2197.

McMahon, P.B., and Chapelle, F.H., 2008, Redox processes and water quality of selected principal aquifer systems: Ground Water, v. 46, no. 2, p. 259-271, http://dx.doi.org/10.1111/j.1745-6584.2007.00385.x.

Minor, S.A., Kellogg, K.S., Stanley, R.G., Gurrola, L.D., Keller, E.A., and Brandt, T.R., 2009, Geologic map of the Santa Barbara coastal plain Area, Santa Barbara County, California: U.S. Geological Survey Scientific Investigations Map 3001, scale 1:25,000, 1 sheet, pamphlet, 38 p., https://pubs.er.usgs.gov/publication/sim3001.

Nakagaki, Naomi, Price, C.V., Falcone, J.A., Hitt, K.J., and Ruddy, B.C., 2007, Enhanced National Land Cover Data 1992 (NLCDe 92): U.S. Geological Survey Raster digital data, http://water.usgs.gov/lookup/getspatial?nlcde92.

Piper, A.M., 1944, A graphic procedure in the geochemical interpretation of water analyses: American Geophysical Union Transactions, v. 25, no. 6, p. 914-923.

Rademacher, L.K., Clark, J.F., and Boles, J.R., 2003, Groundwater residence times and flow paths in fractured rock determined using environmental tracers in the Mission Tunnel; Santa Barbara County, California, USA: Environmental Geology, v. 43, no. 5, p. 557-567.

Reimann, Clemens, and de Caritat, Patrice, 1998, Chemical elements in the environment - Factsheets for the geochemist and environmental scientist: Berlin, Springer-Verlag, 398 p. 
Rowe, B.L., Toccalino, P.L., Moran, M.J., Zogorski, J.S., and Price, C.V., 2007, Occurrence and potential human-health relevance of volatile organic compounds in drinking water from domestic wells in the United States: Environmental Health Perspectives, v. 115, no. 11, p. 1539-1546, http://dx.doi.org/10.1289/ehp.10253.

Saucedo, G.J., Bedford, D.R., Raines, G.L., Miller, R.J., Wentworth, C.M., 2000, GIS Data for the Geologic Map of California, California Geological Survey, CD 2000-07.

Scott, J.C., 1990, Computerized stratified random siteselection approaches for design of a ground-water-quality sampling network: U.S. Geological Survey Water-Resources Investigations Report 90-4101, 109 p., https://pubs.er.usgs.gov/publication/wri904101.

Sparks, D.L., 2003, Environmental soil chemistry, 2d ed.: San Diego, Academic Press, 352 p.

State of California, 2001, Assembly Bill No. 599, Chapter 522, accessed May 27, 2014, at http://swrcb.ca.gov/gama/docs/ ab_599_bill_20011005_chaptered.pdf.

State of California, 2003, Prohibition of MTBE and oxygenates other than ethanol in California gasoline starting December 31, 2003: California Code of Regulations, title 13 , division 3 , chapter 5 , article 1 , subarticle 2 , section 2262.6, http://www.arb.ca.gov/fuels/gasoline/ carfg3_090904.pdf.

Toccalino, P.L., Norman, J.E., Phillips, R.H., Kauffman, L.J., Stackelberg, P.E., Nowell, L.H., Krietzman, S.J., and Post, G.B., 2004, Application of health-based screening levels to ground-water quality data in a statescale pilot effort: U.S. Geological Survey Scientific Investigations Report 2004-5174, 64 p., https://pubs.er.usgs.gov/publication/sir20045174.

Toccalino, P.L., and Norman, J.E., 2006, Health-based screening levels to evaluate U.S. Geological Survey ground water quality data: Risk Analysis, v. 26, no. 5, p. 13391348, http://dx.doi.org/10.1111/j.1539-6924.2006.00805.x.
U.S. Environmental Protection Agency, 1999, National primary drinking water regulations; Radon-222, accessed May 27, 2014, at http://federalregister.gov/a/99-27741.

U.S. Environmental Protection Agency, 2009, Code of Federal Regulations, title 40-Protection of environment, chapter 1-Environmental protection agency, subchapter E-Pesticide programs, part 159Statements of policies and interpretations, subpart DReporting requirements for risk/benefit information, 40 CFR 159.184: National Archives and Records Administration, September 19, 1997; amended June 19, 1998, accessed May 27, 2014, at https://www.gpo.gov/fdsys/pkg/CFR-2012-title40-vol25/ pdf/CFR-2012-title40-vol25-part159.pdf.

U.S. Environmental Protection Agency, 2013, Methyl Tertiary Butyl Ether (MTBE) Overview, accessed May 6, 2014, at http://www.epa.gov/mtbe/faq.htm.

U.S. Environmental Protection Agency, 2016, Drinking Water Contaminants - Standards and Regulations, accessed September 12, 2016, at https://www.epa.gov/dwstandardsregulations.

U.S. Geological Survey, 2004, Resources on isotopesPeriodic table-Boron: U.S. Geological Survey Isotopic Tracers Project, accessed June 23, 2015, at http://wwwrcamnl.wr.usgs.gov/isoig/period/b_iig.html.

United Nations Educational, Scientific, and Cultural Organization (UNESCO), 1979, Map of the world distribution of arid regions - Explanatory note. MAB Technical Notes, v. 7, 42 p., http://unesdoc.unesco.org/ images/0003/000326/032661 eo.pdf.

Zogorski, J.S., Carter, J.M., Ivahnenko, Tamara, Lapham, W.W., Moran, M.J., Rowe, B.L., Squillace, P.J., and Toccalino, P.L., 2006, Volatile organic compounds in the Nation's ground water and drinking-water supply wells: U.S. Geological Survey Circular 1292, 101 p., https://pubs.er.usgs.gov/publication/cir1292. 
Table 1. Classifications by relative-concentrations of organic, special-interest, and inorganic constituents.

$[>$, greater than; $\leq$, less than or equal to]

\begin{tabular}{lcc}
\hline Category & $\begin{array}{c}\text { Relative-concentrations } \\
\text { for organic and special- } \\
\text { interest constituents }\end{array}$ & $\begin{array}{c}\text { Relative- } \\
\text { concentrations for } \\
\text { inorganic constituents }\end{array}$ \\
\hline High & $>1$ & $>1$ \\
Moderate & $>0.1$ and $\leq 1$ & $>0.5$ and $\leq 1$ \\
Low & $\leq 0.1$ & $\leq 0.5$ \\
\hline
\end{tabular}

Table 2. Summary of constituent groups and number of constituents sampled for the Santa Barbara study unit, 2011, California Groundwater Ambient Monitoring and Assessment (GAMA) Priority Basin Project.

[Constituents analyzed by more than one analytical method are only counted once in this report. Abbreviations and symbols: B, boron; C, carbon; $\mathrm{H}$, hydrogen; He, helium; O, oxygen; $\mathrm{Sr}$, strontium; TDS, total disolved solids; $\delta$, delta notation, ratio of the heavier isotope to the lighter isotope of an element, relative to a standard reference material]

\begin{tabular}{|c|c|}
\hline Site type & $\begin{array}{c}\text { Number of } \\
\text { sites sampled }\end{array}$ \\
\hline Grid & 18 \\
\hline Understanding & 6 \\
\hline Total & 24 \\
\hline Constituent type & $\begin{array}{c}\text { Number of } \\
\text { constituents analyzed }\end{array}$ \\
\hline \multicolumn{2}{|l|}{ Organic constituents } \\
\hline Volatile organic compounds (VOCs) & 85 \\
\hline Pesticides and pesticide degradates & 63 \\
\hline Polar pesticides and degradates & 57 \\
\hline Pharmaceuticals & 13 \\
\hline \multicolumn{2}{|c|}{ Constituents of special interest } \\
\hline Perchlorate & 1 \\
\hline$N$-Nitrosodimethylamine (NDMA) & 1 \\
\hline \multicolumn{2}{|l|}{ Inorganic constituents } \\
\hline $\begin{array}{l}\text { Trace elements and major and minor ions } \\
\text { (including alkalinity and TDS) }\end{array}$ & 35 \\
\hline Nutrients & 5 \\
\hline \multicolumn{2}{|c|}{ Uranium and radioactive constituents } \\
\hline Uranium & 1 \\
\hline Gross alpha and beta radioactivity ${ }^{1}$ & 2 \\
\hline Radon-222 & 1 \\
\hline \multicolumn{2}{|c|}{ Geochemical and isotope tracers } \\
\hline $\begin{array}{l}\text { Dissolved oxygen, } \mathrm{pH} \text {, specific } \\
\text { conductance, and temperature }\end{array}$ & 4 \\
\hline Arsenic, chromium, and iron species & 3 \\
\hline$\delta^{2} \mathrm{H}$ and $\delta^{18} \mathrm{O}$ stable isotopes of water & 2 \\
\hline$\delta^{11} \mathrm{~B}$ in water & 1 \\
\hline${ }^{87} \mathrm{Sr} /{ }^{86} \mathrm{Sr}$ of dissolved strontium & 1 \\
\hline Carbon-14 and $\delta^{13} \mathrm{C}$ of dissolved carbonates & 2 \\
\hline $\begin{array}{l}\text { Dissolved noble gases (argon, helium, } \\
\text { neon, krypton, xenon), }{ }^{3} \mathrm{He} /{ }^{4} \mathrm{He} \text { of helium }\end{array}$ & 6 \\
\hline Tritium & 1 \\
\hline Total & 284 \\
\hline
\end{tabular}


Table 3. Comparison of the number of compounds and median method detection limits (MDLs), by constituent class, for data stored in the California Department of Public Health (CDPH) database and data collected for the Santa Barbara study unit, 2011, California Groundwater Ambient Monitoring and Assessment (GAMA) Priority Basin Project.

[Abbreviations: mg/L, milligrams per liter; na, not available; pCi/L, picoCuries per liter; USGS, U.S. Geological Survey; $\mu \mathrm{g} / \mathrm{L}$, micrograms per liter]

\begin{tabular}{|c|c|c|c|c|c|}
\hline \multirow[b]{2}{*}{ Constituent class } & \multicolumn{2}{|c|}{ CDPH } & \multicolumn{2}{|c|}{ USGS-GAMA } & \multirow{2}{*}{$\begin{array}{c}\text { Media } \\
\text { units }\end{array}$} \\
\hline & $\begin{array}{c}\text { Number of } \\
\text { constituents }\end{array}$ & $\begin{array}{c}\text { Median } \\
\text { MDL }\end{array}$ & $\begin{array}{c}\text { Number of } \\
\text { constituents }\end{array}$ & $\begin{array}{c}\text { Median } \\
\text { MDL }\end{array}$ & \\
\hline Pesticides and pesticide degradates & 55 & 1 & 120 & 0.03 & $\mu \mathrm{g} / \mathrm{L}$ \\
\hline Pharmaceutical constituents & na & na & 13 & 0.04 & $\mu \mathrm{g} / \mathrm{L}$ \\
\hline Trace elements & 19 & 10 & 23 & 0.06 & $\mu \mathrm{g} / \mathrm{L}$ \\
\hline Nutrients & 4 & 0.4 & 5 & 0.01 & $\mathrm{mg} / \mathrm{L}$ \\
\hline Major and minor ions & 8 & 0.1 & 12 & 0.03 & $\mathrm{mg} / \mathrm{L}$ \\
\hline Uranium and radioactive constituents & 6 & 3 & 4 & ${ }^{1} 1.4$ & $\mathrm{pCi} / \mathrm{L}$ \\
\hline
\end{tabular}

\footnotetext{
${ }^{1}$ The median detection level for USGS-GAMA radioactive constituents was calculated from the median of sample specific critical levels for gross alpha and
} gross beta radioactivity (72-hour count) and radon from the 18 Santa Barbara grid samples. 
Table 4. Number of constituents analyzed and detected at grid sites, by constituent class and benchmark type, Santa Barbara study unit, 2011, California Groundwater Ambient Monitoring and Assessment (GAMA) Priority Basin Project.

[Benchmark type: Regulatory, health-based benchmarks include U.S. Environmental Protection Agency (USEPA) and California Department of Public Health (CDPH) maximum contaminant levels and USEPA action levels. Non-regulatory, health-based benchmarks include USEPA health advisory levels and risk-specific doses at $10^{-5}$ and CDPH notification levels. Non-regulatory, aesthetic-based benchmarks include USEPA and CDPH secondary maximum contaminant levels.]

\begin{tabular}{|c|c|c|c|c|c|c|c|c|c|c|}
\hline \multirow{4}{*}{ Benchmark type } & \multicolumn{10}{|c|}{ Groups of organic and special-interest constituents } \\
\hline & \multicolumn{2}{|c|}{$\begin{array}{c}\text { Volatile organic } \\
\text { compounds }\end{array}$} & \multicolumn{2}{|c|}{$\begin{array}{c}\text { Pesticides and } \\
\text { pesticide degradates }\end{array}$} & \multicolumn{2}{|c|}{$\begin{array}{c}\text { Pharmaceutical } \\
\text { compounds }\end{array}$} & \multicolumn{2}{|c|}{$\begin{array}{l}\text { Sum of organic } \\
\text { constituents }\end{array}$} & \multicolumn{2}{|c|}{$\begin{array}{c}\text { Special-interest } \\
\text { constituents }\end{array}$} \\
\hline & \multicolumn{10}{|c|}{ Number of constituents } \\
\hline & Analyzed & Detected & Analyzed & Detected & Analyzed & Detected & Analyzed & Detected & Analyzed & Detected \\
\hline Regulatory, health-based & 34 & 8 & 8 & 1 & 0 & 0 & 42 & 9 & 1 & 1 \\
\hline Non-regulatory, health-based & 24 & 0 & 32 & 0 & 0 & 0 & 56 & 0 & 1 & 0 \\
\hline Non-regulatory, aesthetic-based & 0 & 0 & 0 & 0 & 0 & 0 & 0 & 0 & 0 & 0 \\
\hline None & 27 & 1 & 80 & 0 & 13 & 0 & 120 & 1 & 0 & 0 \\
\hline Total: & 85 & 9 & 120 & 1 & 13 & 0 & 218 & 10 & 2 & 1 \\
\hline \multirow{4}{*}{ Benchmark type } & \multicolumn{10}{|c|}{ Groups of inorganic constituents } \\
\hline & \multicolumn{2}{|c|}{$\begin{array}{l}\text { Trace elements and } \\
\text { major and minor ions }\end{array}$} & \multicolumn{2}{|c|}{ Nutrients } & \multirow{2}{*}{\multicolumn{2}{|c|}{$\begin{array}{l}\text { Uranium and } \\
\text { radioactive constituents } \\
\text { Number of constituents } \\
\end{array}$}} & \multicolumn{2}{|c|}{$\begin{array}{c}\text { Sum of inorganic } \\
\text { constituents }\end{array}$} & \multicolumn{2}{|c|}{$\begin{array}{l}\text { Geochemical and } \\
\text { isotope tracers }\end{array}$} \\
\hline & & & & & & & & & & \\
\hline & Analyzed & Detected & Analyzed & Detected & Analyzed & Detected & Analyzed & Detected & Analyzed & Detected \\
\hline Regulatory, health-based & 14 & 13 & 2 & 2 & 4 & 4 & 20 & 19 & 1 & 1 \\
\hline Non-regulatory, health-based & 4 & 4 & 1 & 1 & 0 & 0 & 5 & 5 & 0 & 0 \\
\hline Non-regulatory, aesthetic-based & 7 & 7 & 0 & 0 & 0 & 0 & 7 & 7 & 2 & 2 \\
\hline None & 10 & 10 & 2 & 2 & 0 & 0 & 12 & 12 & 17 & 17 \\
\hline Total: & 35 & 34 & 5 & 5 & 4 & 4 & 44 & 43 & 20 & 20 \\
\hline
\end{tabular}


Table 5. Constituents reported at concentrations greater than benchmarks historically (March 23, 1984, through January 23, 2008) in the California Department of Public Health (CDPH) database, Santa Barbara study unit, 2011, California Groundwater Ambient Monitoring and Assessment (GAMA) Priority Basin Project.

[Benchmark type: MCL-US, U.S. Environmental Protection Agency (USEPA) maximum contaminant level; MCL-CA, CDPH maximum contaminant level; AL-US, USEPA action level; SMCL-CA, CDPH secondary maximum contaminant level. Abbreviations: $\mathrm{pCi} / \mathrm{L}$, picoCuries per liter; mg/L, milligrams per liter; USGS, U.S. Geological Survey; $\mu \mathrm{g} / \mathrm{L}$, micrograms per liter]

\begin{tabular}{|c|c|c|c|c|c|c|}
\hline \multirow{2}{*}{ Constituent } & \multicolumn{3}{|c|}{ Benchmark } & \multirow{2}{*}{$\begin{array}{c}\text { Date of most } \\
\text { recent high value }\end{array}$} & \multirow{2}{*}{$\begin{array}{c}\text { Number of sites } \\
\text { with historical data }\end{array}$} & \multirow{2}{*}{$\begin{array}{l}\text { Number of sites } \\
\text { with a high value }\end{array}$} \\
\hline & Type & Value & Units & & & \\
\hline \multicolumn{7}{|c|}{ Inorganics with health-based benchmarks ${ }^{1}$} \\
\hline Arsenic $^{3}$ & MCL-US & 10 & $\mu \mathrm{g} / \mathrm{L}$ & $09 / 21 / 88$ & 74 & 2 \\
\hline Barium $^{4}$ & MCL-CA & 1,000 & $\mu \mathrm{g} / \mathrm{L}$ & $04 / 19 / 05$ & 74 & 1 \\
\hline Lead & AL-US & 15 & $\mu \mathrm{g} / \mathrm{L}$ & $07 / 24 / 91$ & 74 & 1 \\
\hline \multicolumn{7}{|c|}{ Nutrients } \\
\hline Nitrate (as nitrogen) ${ }^{6}$ & MCL-US & 10 & $\mathrm{mg} / \mathrm{L}$ & $10 / 13 / 03$ & 85 & 4 \\
\hline Nitrite (as nitrogen) ${ }^{6}$ & MCL-US & 1 & $\mathrm{mg} / \mathrm{L}$ & $02 / 23 / 06$ & 54 & 1 \\
\hline \multicolumn{7}{|c|}{ Uranium and radioactive constituents } \\
\hline Iron & SMCL-CA & 300 & $\mu \mathrm{g} / \mathrm{L}$ & $06 / 04 / 07$ & 78 & 32 \\
\hline Manganese & SMCL-CA & 50 & $\mu \mathrm{g} / \mathrm{L}$ & $01 / 07 / 08$ & 77 & 42 \\
\hline Sulfate & SMCL-CA & 500 & $\mathrm{mg} / \mathrm{L}$ & $02 / 28 / 07$ & 73 & 2 \\
\hline Total dissolved solids (TDS) & SMCL-CA & 1,000 & $\mathrm{mg} / \mathrm{L}$ & $02 / 28 / 07$ & 73 & 14 \\
\hline \multicolumn{7}{|c|}{ Volatile organic compounds (VOCs) } \\
\hline Perchloroethene & MCL-US & 5 & $\mu \mathrm{g} / \mathrm{L}$ & $07 / 08 / 03$ & 79 & 1 \\
\hline Chloroform & MCL-US & 80 & $\mu \mathrm{g} / \mathrm{L}$ & $07 / 17 / 01$ & 79 & 2 \\
\hline Total trihalomethanes ${ }^{8}$ & MCL-US & 80 & $\mu \mathrm{g} / \mathrm{L}$ & $08 / 14 / 02$ & 79 & 4 \\
\hline
\end{tabular}

${ }^{1}$ Inorganics for these constituent classes include trace elements and major and minor ions.

${ }^{2}$ The high value for aluminum was 2,500, which likely is a reporting error. All 10 other aluminum results for this site in the CDPH database analyzed between June 1989 and June 2009 ranged from non-detections to 20. Aluminum was not detected in the sample collected from this site for USGS-GAMA.

${ }^{3}$ The high values for arsenic both were 20; all other 14 arsenic results for the 2 sites in the CDPH database analyzed between August 1984 and April 2007 ranged from non-detections to 2.6; arsenic was detected at less than 1 in the sample collected from 1 of these sites for USGS-GAMA.

${ }^{4}$ The high value for barium was 2,060, which likely was a reporting error; the same site had a value of 77 the next day.

${ }^{5}$ One of the high values for fluoride was 4.3 , which likely was a reporting error; the high value was detected in the same sample that had a high barium value discussed previously. The second high value for fluoride was 3.1; water from the same site had fluoride values at 0.4 or less in samples collected 19,44 , and 77 months later.

${ }^{6}$ Nitrate data are reported "as nitrate" in the CDPH database and were converted to "as nitrogen" in this report for comparison with other CDPH nutrient results and USGS results. The CDPH database contains data for nitrate plus nitrite; however, there are fewer results than for nitrate: 52 wells with analysis and 1 high value. The sample with a high value of nitrite was also sampled for nitrate and is included in the count for number of sites with a high value for nitrate. The high value for nitrite was 1.1; water from the same sample had reported concentrations for nitrate plus nitrite (as nitrogen) of 2 and nitrate (as nitrogen) of 1.65. All other 24 nitrite results for this site in the CDPH database analyzed between February 2005 and July 2010 were non-detections.

${ }^{7}$ Values for gross alpha radioactivity were not adjusted for uranium activity. One site where the groundwater sample had a high gross-alpha radioactivity value also had the high uranium value; the other two sites did not have results in the CDPH database for uranium activity.

${ }^{8}$ One of the high values for total trihalomethanes (TTHM) was 92.2; however, the sum of the four trihalomethanes analyzed (bromodichloromethane, bromoform, dibromochloromethane, and chloroform) was 52.5. All other 11 TTHM results for this well in the CDPH database analyzed between May 1989 and April 2007 were below the benchmark. No VOCs were detected in the sample collected by USGS-GAMA at the same site. 
Table 6. Aquifer-scale proportions from grid-based and spatially weighted methods, Santa Barbara study unit, 2011, California Groundwater Ambient Monitoring and Assessment (GAMA) Priority Basin Project for constituents detected at high relative-concentrations during the most recent 3 years of available data (January 24,2008 through January 23, 2011); constituents detected at high or moderate relative-concentrations at grid sites; or organic constituents detected at any concentration with detection frequencies greater than 10 percent in samples collected from grid sites.

[Grid-based aquifer proportions for organic constituents are based on samples collected by the U.S. Geological Survey (USGS) at 18 grid sites during January to February 2011. Spatially weighted aquifer proportions are based on California Department of Public Health (CDPH) data from the period January 24, 2008, through January 23, 2011, in combination with data from the 18 grid sites and 5 understanding sites. Concentration category: high, concentrations greater than benchmark; moderate, concentrations less than or equal to benchmark and greater than 0.1 (for organic and special-interest constituents) or 0.5 (for inorganics) of benchmark; low, concentrations less than or equal to 0.1 (for organics) or 0.5 (for inorganics) of benchmark. Benchmark type: HAL-US, USEPA health advisory level; MCL-CA, CDPH maximum contaminant level; MCL-US, U.S. Environmental Protection Agency (USEPA) maximum contaminant level; NL-CA, CDPH notification level; SMCL-CA, CDPH secondary maximum contaminant level. Abbreviations: $\mathrm{mg} / \mathrm{L}$, milligrams per liter; $\mathrm{pCi} / \mathrm{L}$, picoCuries per liter; $\mu \mathrm{g} / \mathrm{L}$, micrograms per liter]

\begin{tabular}{|c|c|c|c|c|c|c|c|c|c|c|c|c|c|c|}
\hline \multirow[t]{2}{*}{ Constituent } & \multicolumn{3}{|c|}{ Benchmark } & \multicolumn{3}{|c|}{ Raw detection frequency } & \multicolumn{3}{|c|}{$\begin{array}{c}\text { Grid-based } \\
\text { aquifer proportions } \\
\text { (percent) }\end{array}$} & \multicolumn{3}{|c|}{$\begin{array}{l}\text { Spatially weighted } \\
\text { aquifer proportions } \\
\text { (percent) }\end{array}$} & \multicolumn{2}{|c|}{$\begin{array}{c}90 \text {-percent } \\
\text { confidence interval } \\
\text { for grid-based high } \\
\text { proportion }\end{array}$} \\
\hline & Type & Value & Units & $\begin{array}{c}\text { Number } \\
\text { of sites }\end{array}$ & $\begin{array}{l}\text { Percentage } \\
\text { moderate }\end{array}$ & $\begin{array}{c}\text { Percentage } \\
\text { high }\end{array}$ & $\begin{array}{l}\text { Number } \\
\text { of cells }\end{array}$ & $\begin{array}{c}\text { Proportion } \\
\text { moderate }\end{array}$ & $\begin{array}{c}\text { Proportion } \\
\text { high }\end{array}$ & $\begin{array}{l}\text { Number } \\
\text { of cells }\end{array}$ & $\begin{array}{c}\text { Proportion } \\
\text { moderate }\end{array}$ & $\begin{array}{c}\text { Proportion } \\
\text { high }\end{array}$ & $\begin{array}{c}\text { Lower } \\
\text { limit }\end{array}$ & $\begin{array}{c}\text { Upper } \\
\text { limit }\end{array}$ \\
\hline \multicolumn{15}{|c|}{ Inorganics with health-based benchmarks ${ }^{1}$} \\
\hline Boron & NL-CA & 1,000 & $\mu \mathrm{g} / \mathrm{L}$ & 35 & 0 & 2.9 & 19 & 0 & 5.3 & 19 & 0 & 5.3 & 0.9 & 19 \\
\hline Fluoride & MCL-CA & 2 & $\mathrm{mg} / \mathrm{L}$ & 40 & 2.5 & 2.5 & 19 & 5.3 & 5.3 & 19 & 5.3 & 5.3 & 0.9 & 19 \\
\hline Strontium & HAL-US & 4,000 & $\mu \mathrm{g} / \mathrm{L}$ & 23 & 4.3 & 0 & 18 & 5.6 & 0 & 18 & 5.6 & 0 & 0 & 7.1 \\
\hline \multicolumn{15}{|c|}{ Nutrients } \\
\hline $\begin{array}{l}\text { Nitrate plus nitrite } \\
\quad \text { (as nitrogen) }\end{array}$ & MCL-US & 10 & $\mathrm{mg} / \mathrm{L}$ & 49 & 8.2 & 2.0 & 19 & 16 & 0 & 19 & 6.5 & 1.3 & 0 & 6.8 \\
\hline \multicolumn{15}{|c|}{ Uranium and radioactive constituents } \\
\hline $\begin{array}{l}\text { Gross alpha } \\
\text { radioactivity }\end{array}$ & MCL-US & 15 & $\mathrm{pCi} / \mathrm{L}$ & 33 & 9.1 & 0 & 18 & 17 & 0 & 18 & 17 & 0 & 0 & 7.1 \\
\hline $\begin{array}{l}\text { Adjusted gross alpha } \\
\text { radioactivity }{ }^{2}\end{array}$ & MCL-US & 15 & $\mathrm{pCi} / \mathrm{L}$ & 33 & 0 & 0 & 18 & 0 & 0 & 18 & 0 & 0 & 0 & 7.1 \\
\hline \multicolumn{15}{|c|}{ Inorganics with aesthetic-based benchmarks ${ }^{1}$} \\
\hline Chloride & SMCL-CA & 500 & $\mathrm{mg} / \mathrm{L}$ & 40 & 15 & 0 & 19 & 21 & 0 & 19 & 15 & 0 & 0 & 6.8 \\
\hline Iron & SMCL-CA & 300 & $\mu \mathrm{g} / \mathrm{L}$ & 40 & 10 & 22 & 19 & 16 & 16 & 19 & 7.4 & 25 & 6.0 & 33 \\
\hline Manganese & SMCL-CA & 50 & $\mu \mathrm{g} / \mathrm{L}$ & 40 & 7.5 & 42 & 19 & 11 & 37 & 19 & 4.6 & 40 & 21 & 56 \\
\hline Sulfate & SMCL-CA & 500 & $\mathrm{mg} / \mathrm{L}$ & 40 & 35 & 5.0 & 19 & 37 & 5.3 & 19 & 33 & 5.3 & 0.9 & 19 \\
\hline $\begin{array}{r}\text { Total dissolved } \\
\text { solids (TDS) }\end{array}$ & SMCL-CA & 1,000 & $\mathrm{mg} / \mathrm{L}$ & 40 & 68 & 25 & 19 & 63 & 32 & 19 & 66 & 27 & 17 & 50 \\
\hline
\end{tabular}


Table 6. Aquifer-scale proportions from grid-based and spatially weighted methods, Santa Barbara study unit, 2011, California Groundwater Ambient Monitoring and

Assessment (GAMA) Priority Basin Project for constituents detected at high relative-concentrations during the most recent 3 years of available data (January 24, 2008 through January 23, 2011); constituents detected at high or moderate relative-concentrations at grid sites; or organic constituents detected at any concentration with detection frequencies greater than 10 percent in samples collected from grid sites. - Continued

[Grid-based aquifer proportions for organic constituents are based on samples collected by the U.S. Geological Survey (USGS) at 18 grid sites during January to February 2011 . Spatially weighted aquifer proportions are based on California Department of Public Health (CDPH) data from the period January 24, 2008, through January 23, 2011, in combination with data from the 18 grid sites and 5 understanding sites. Concentration category: high, concentrations greater than benchmark; moderate, concentrations less than or equal to benchmark and greater than 0.1 (for organic and special-interest constituents) or 0.5 (for inorganics) of benchmark; low, concentrations less than or equal to 0.1 (for organics) or 0.5 (for inorganics) of benchmark. Benchmark type: HAL-US, USEPA health advisory level; MCL-CA, CDPH maximum contaminant level; MCL-US, U.S. Environmental Protection Agency (USEPA) maximum contaminant level; NL-CA, CDPH notification level; SMCL-CA, CDPH secondary maximum contaminant level. Abbreviations: $\mathrm{mg} / \mathrm{L}$, milligrams per liter; $\mathrm{pCi} / \mathrm{L}$, picoCuries per liter; $\mu \mathrm{g} / \mathrm{L}$, micrograms per liter]

\begin{tabular}{|c|c|c|c|c|c|c|c|c|c|c|c|c|c|c|}
\hline \multirow[t]{2}{*}{ Constituent } & \multicolumn{3}{|c|}{ Benchmark } & \multicolumn{3}{|c|}{ Raw detection frequency } & \multicolumn{3}{|c|}{$\begin{array}{c}\text { Grid-based } \\
\text { aquifer proportions } \\
\text { (percent) }\end{array}$} & \multicolumn{3}{|c|}{$\begin{array}{l}\text { Spatially weighted } \\
\text { aquifer proportions } \\
\text { (percent) }\end{array}$} & \multicolumn{2}{|c|}{$\begin{array}{c}90 \text {-percent } \\
\text { confidence interval } \\
\text { for grid-based high } \\
\text { proportion }\end{array}$} \\
\hline & Type & Value & Units & $\begin{array}{l}\text { Number } \\
\text { of sites }\end{array}$ & $\begin{array}{c}\text { Percentage } \\
\text { moderate }\end{array}$ & $\begin{array}{l}\text { Percentage } \\
\text { high }\end{array}$ & $\begin{array}{l}\text { Number } \\
\text { of cells }\end{array}$ & $\begin{array}{l}\text { Proportion } \\
\text { moderate }\end{array}$ & $\begin{array}{c}\text { Proportion } \\
\text { high }\end{array}$ & $\begin{array}{c}\text { Number } \\
\text { of cells }\end{array}$ & $\begin{array}{c}\text { Proportion } \\
\text { moderate }\end{array}$ & $\begin{array}{c}\text { Proportion } \\
\text { high }\end{array}$ & $\begin{array}{l}\text { Lower } \\
\text { limit }\end{array}$ & $\begin{array}{l}\text { Upper } \\
\text { limit }\end{array}$ \\
\hline \multicolumn{15}{|c|}{ Volatile organic compounds } \\
\hline $\begin{array}{l}\text { Chloroform (total } \\
\text { trihalomethanes) }\end{array}$ & MCL-US & 80 & $\mu \mathrm{g} / \mathrm{L}$ & 39 & 0 & 0 & 17 & 0 & 0 & 18 & 0 & 0 & 0 & 7.1 \\
\hline $\begin{array}{l}\text { 1,1,1-Trichloro- } \\
\text { ethane }\end{array}$ & MCL-US & 200 & $\mu \mathrm{g} / \mathrm{L}$ & 40 & 0 & 0 & 18 & 0 & 0 & 18 & 0 & 0 & 0 & 7.1 \\
\hline 1,1-Dichloroethane & MCL-CA & 5 & $\mu \mathrm{g} / \mathrm{L}$ & 40 & 0 & 0 & 18 & 0 & 0 & 18 & 0 & 0 & 0 & 7.1 \\
\hline Perchloroethene & MCL-US & 5 & $\mu \mathrm{g} / \mathrm{L}$ & 40 & 2.5 & 0 & 18 & 0 & 0 & 18 & 1.4 & 0 & 0 & 7.1 \\
\hline $\begin{array}{l}\text { Methyl tert-butyl } \\
\text { ether }\end{array}$ & MCL-CA & 13 & $\mu \mathrm{g} / \mathrm{L}$ & 40 & 5.0 & 0 & 18 & 11 & 0 & 18 & 2.2 & 0 & 0 & 7.1 \\
\hline 1,2-Dichloroethane & MCL-CA & 0.5 & $\mu \mathrm{g} / \mathrm{L}$ & 40 & 2.5 & 0 & 18 & 5.6 & 0 & 18 & 1.4 & 0 & 0 & 7.1 \\
\hline \multicolumn{15}{|c|}{ Pesticides and pesticide degradates } \\
\hline Simazine & MCL-US & 4 & $\mu \mathrm{g} / \mathrm{L}$ & 38 & 0 & 0 & 18 & 0 & 0 & 19 & 0 & 0 & 0 & 7.1 \\
\hline \multicolumn{15}{|c|}{ Constituents of special interest } \\
\hline Perchlorate & MCL-US & 6 & $\mu \mathrm{g} / \mathrm{L}$ & 46 & 22 & 0 & 18 & 50 & 0 & 18 & 31 & 0 & 0 & 7.1 \\
\hline
\end{tabular}

${ }^{1}$ Inorganics for these constituent classes include trace elements and major and minor ions.

${ }^{2}$ Adjusted gross alpha radioactivity is provided for comparison and is equal to gross alpha radioactivity minus uranium activity.

${ }^{3}$ Aquifer-scale proportions of total trihalomethanes in the Santa Barbara study unit primarily were determined by detections of chloroform. The trihalomethane bromodichloromethane was also detected, but only at low concentrations in samples from two grid wells that also had chloroform detections. 
Table 7. Summary of aquifer-scale proportions for inorganic, organic, and special-interest constituent classes, Santa Barbara study unit, 2011, California Groundwater Ambient Monitoring and Assessment (GAMA) Priority Basin Project.

[Concentration category: high, concentrations greater than benchmark; moderate, concentrations less than or equal to benchmark and greater than 0.5 (or 0.1 for organics) of benchmark; low, concentrations less than or equal to 0.5 (or 0.1 for organics) of benchmark. Aquifer-scale proportions greater than 10 percent are rounded to the nearest 1 percent; values less than 10 percent are rounded to the nearest 0.1 percent. Values may not add up to 100 percent because of rounding. Abbreviations: na, not available; TDS, total dissolved solids]

\begin{tabular}{|c|c|c|c|c|c|}
\hline \multirow{2}{*}{ Constituent class } & \multirow{2}{*}{$\begin{array}{l}\text { Number of } \\
\text { cells }\end{array}$} & \multicolumn{4}{|c|}{ Aquifer-scale proportions (percent) } \\
\hline & & Not detected $^{1}$ & Proportion low & Proportion moderate & Proportion high \\
\hline \multicolumn{6}{|c|}{ Inorganics with health-based benchmarks } \\
\hline Nutrients & 19 & na & 83 & 16 & ${ }^{2} 1.3$ \\
\hline Uranium and radioactive constituents & 18 & na & 83 & 17 & 0 \\
\hline \multicolumn{6}{|c|}{ Inorganics with aesthetic-based benchmarks } \\
\hline Iron and (or) manganese (redox indicators) & 19 & na & 42 & 21 & 37 \\
\hline TDS, sulfate, and (or) chloride (salinity indicators) & 19 & na & 5.3 & 63 & 32 \\
\hline Any inorganic constituent & 19 & na & 5.3 & 37 & 58 \\
\hline \multicolumn{6}{|c|}{ Organics with health-based benchmarks } \\
\hline Any volatile organic compound & 18 & 44 & 44 & 11 & 0 \\
\hline Pesticides & 18 & 89 & 11 & 0 & 0 \\
\hline Any organic constituent & 18 & 39 & 50 & 11 & 0 \\
\hline \multicolumn{6}{|c|}{ Constituents of special interest } \\
\hline Perchlorate & 18 & 33 & 17 & 50 & 0 \\
\hline
\end{tabular}

${ }^{1}$ Non-detections are included in the calculation of low aquifer-scale proportions for inorganic constituents.

${ }^{2}$ Spatially weighted value. 


\section{Appendix 1. Additional Information about Data used in the Status Assessment}

\section{Selection of California Department of Public Health and U.S. Geological Survey Data}

California requires samples to be collected regularly from public-supply wells under Title 22 (California State Water Resources Control Board, 2016). Historical data derived from these samples are available from the California Department of Public Health (CDPH) database. Assembly Bill 599 directs the Groundwater Ambient Monitoring and Assessment (GAMA) Program to use available data and to collect new data as needed. The GAMA Priority Basin Project used the existing monitoring data along with newly collected data to characterize the water quality of the primary aquifer system. The CDPH database provided additional water-quality data for the spatially weighted and grid-based approaches to estimating aquifer-scale proportions for a wide range of constituents. The CDPH data were not used to provide data for grid sites for volatile organic compounds (VOCs), pesticides, pharmaceuticals, NDMA, or perchlorate, because reporting limits for these constituents in the CDPH database generally were not sufficiently low to differentiate between "low" and "moderate" concentrations. For the Santa Barbara study unit, the historical CDPH database contained more than 1,626 records distributed among 78 wells, requiring targeted retrievals to manageably use the data to assess water quality. The CDPH database was used to provide data to represent grid cells for which there were no U.S. Geological Survey (USGS) grid sites sampled (for the grid-based and spatially weighted calculations of aquifer-scale proportions) and to provide additional data for each grid cell (for the spatially weighted calculations).

In the Santa Barbara study unit, 2 of the 20 grid cells did not have USGS-GAMA sites, and 2 additional cells were missing radon data from the USGS-GAMA dataset. The CDPH did not contain radon data for samples collected between January 2008 and January 2011. Of the two cells without USGS-GAMA grid sites, only one contained a CDPH well that had data for water samples collected between January 2008 and January 2011. The data from this well (SB-DPH-19; table 1-1; fig. 1-1) were selected for use in the grid-based calculations of aquifer-scale proportions. The CDPH data available for SB-DPH-19 were simazine (for spatially weighted calculation only), boron, fluoride, nitrate, chloride, iron, manganese, sulfate, and TDS. In other GAMA Priority Basin Project study units, grid cells without complete water-quality data from a USGS grid well typically contained more than one CDPH well, and a prioritization process was required to select data from among those wells (for example, Parsons and others, 2014).

\section{Comparison of California Department of Public Health and USGS-GAMA Data}

The CDPH and USGS-GAMA data were compared to assess the validity of combining data for inorganic constituents from these different sources for use in calculations of aquiferscale proportions. Because laboratory reporting levels for most organic constituents and trace elements were substantially lower for USGS-GAMA data than for CDPH data (table 3), only relatively high concentrations of constituents could be compared; as a result, there were insufficient data from which to evaluate agreement between CDPH and USGS-GAMA data. Concentrations of major ions and nitrate, which generally are substantially above reporting levels, could be compared for each site by using data from both sources, however. Nine sites had major ion and nitrate data from the USGS database and the CDPH database. Although differences between the paired datasets existed for some sites, most sample pairs with detections in both datasets plotted close to a 1-to-1 line (fig. 1-2). A nonparametric signed-rank test indicated a positive bias for the USGS-GAMA dataset relative to the CDPH dataset $(p=0.005)$, in particular for fluoride and total dissolved solids (TDS). The relative standard deviation (RSD) was calculated for each of the 85 data pairs. The median RSD was 4.2 percent; 90 percent of the RSD values were less than 20 percent. Differences between the paired USGS-GAMA and $\mathrm{CDPH}$ data for the 10 constituents were not likely to affect interpretation of inorganic data in the study unit.

Major-ion data for grid sites that had sufficient groundwater data (USGS and CDPH data) were plotted on a Piper diagram (Piper, 1944; Hem, 1985) along with all the CDPH major-ion data to determine whether the groundwater types in samples from the grid sites were similar to the groundwater types historically observed in the study unit. All major-ion data in the CDPH database that had a cation/ anion imbalance of less than 10 percent were retrieved and plotted on the Piper diagram for comparison with data from the USGS grid sites. The ranges of water types for USGSGAMA sites and sites from the historical CDPH database were similar (fig. 1-3). For samples from most USGS grid sites (83 percent) and all CDPH sites, no single cation accounted for more than 60 percent of the total cations, and no single anion accounted for more than 60 percent of the total anions. Water in these wells is described as mixed cation-mixed anion type water. The determination that the range of relative abundance of major cations and anions at USGS grid sites was similar to the range of those at all CDPH sites indicated that the grid sites represent most of the types of water present in the Santa Barbara study unit. 


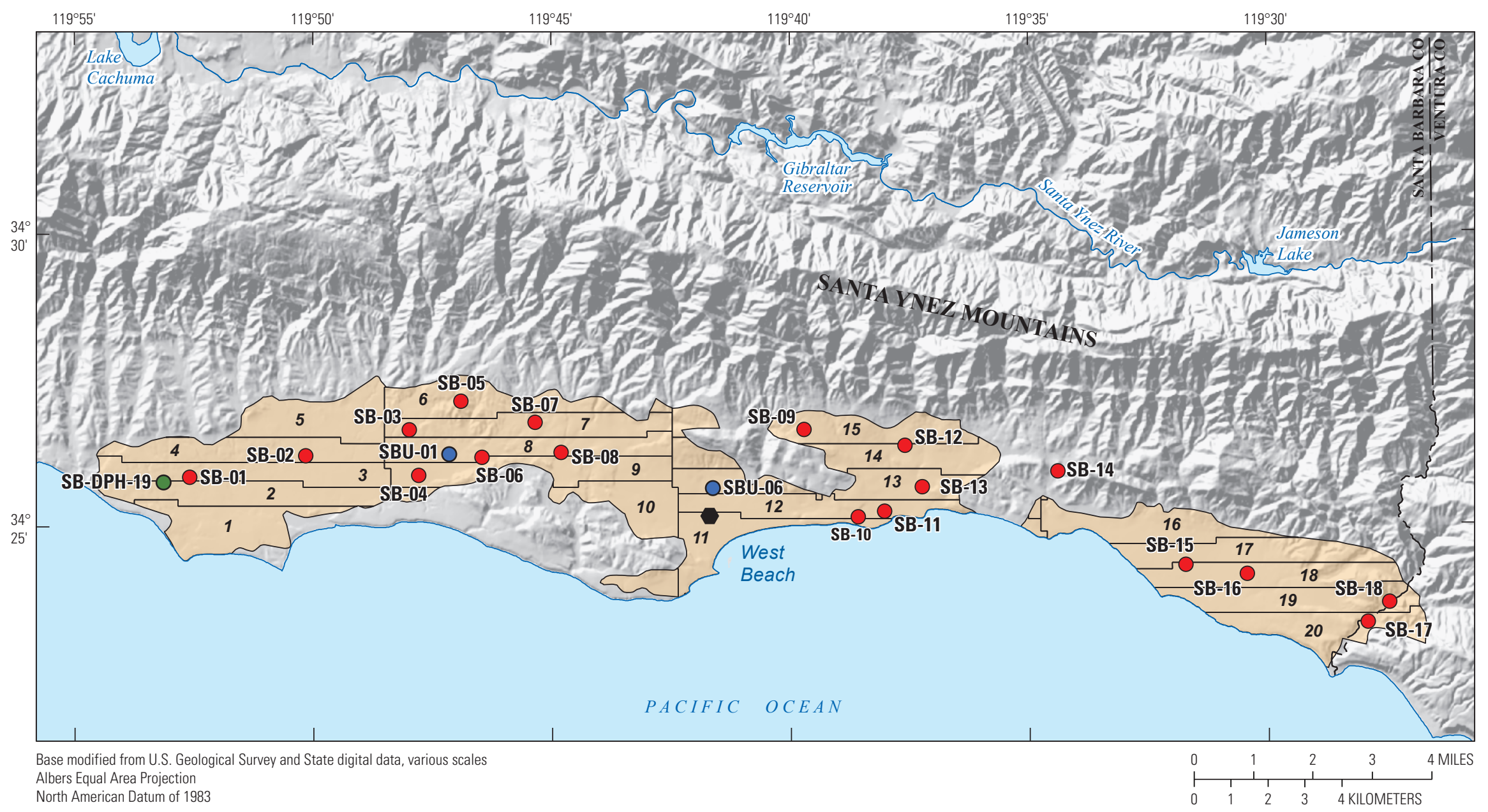

EXPLANATION

Grid cells

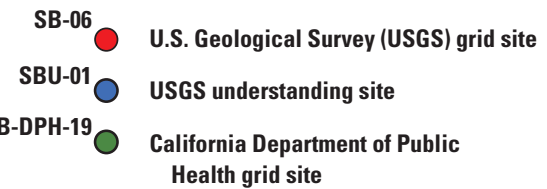

SBU-05

USGS monitoring-well cluste

SBU-02 Health grid site

Figure 1-1. Locations of U.S. Geological Survey (USGS) grid, California Department of Public Health (CDPH) grid, and USGS understanding sites and grid cells, Santa Barbara study unit, 2011, California Groundwater Ambient Monitoring and Assessment (GAMA) Priority Basin Project. 


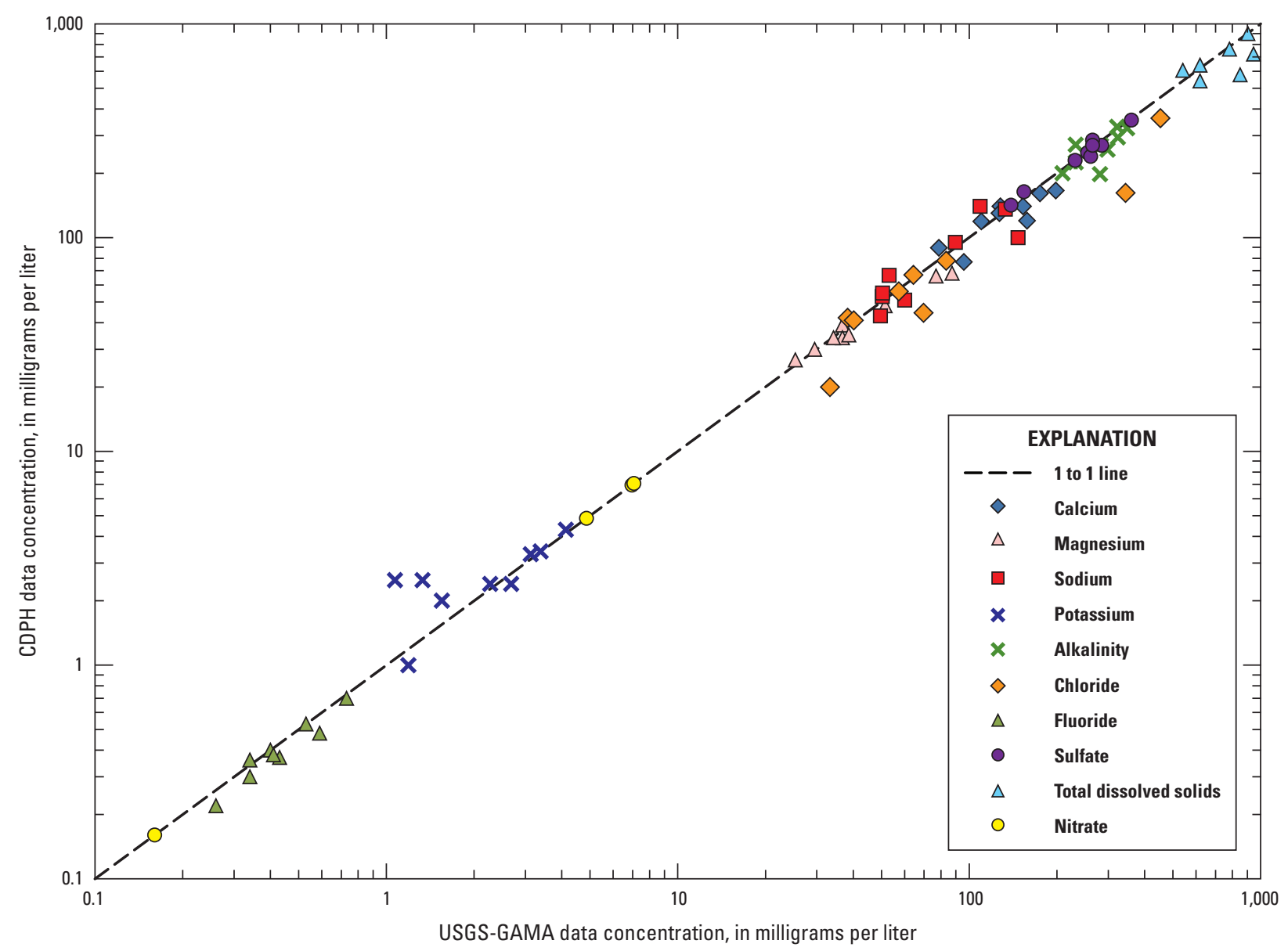

Figure 1-2. Paired inorganic constituent concentrations from sites sampled by U.S. Geological Survey (USGS), January 24, 2011February 16, 2011, and by California Department of Public Health (CDPH), January 24, 2008-January 23, 2011, Santa Barbara study unit, 2011, California Groundwater Ambient Monitoring and Assessment (GAMA) Priority Basin Project. 


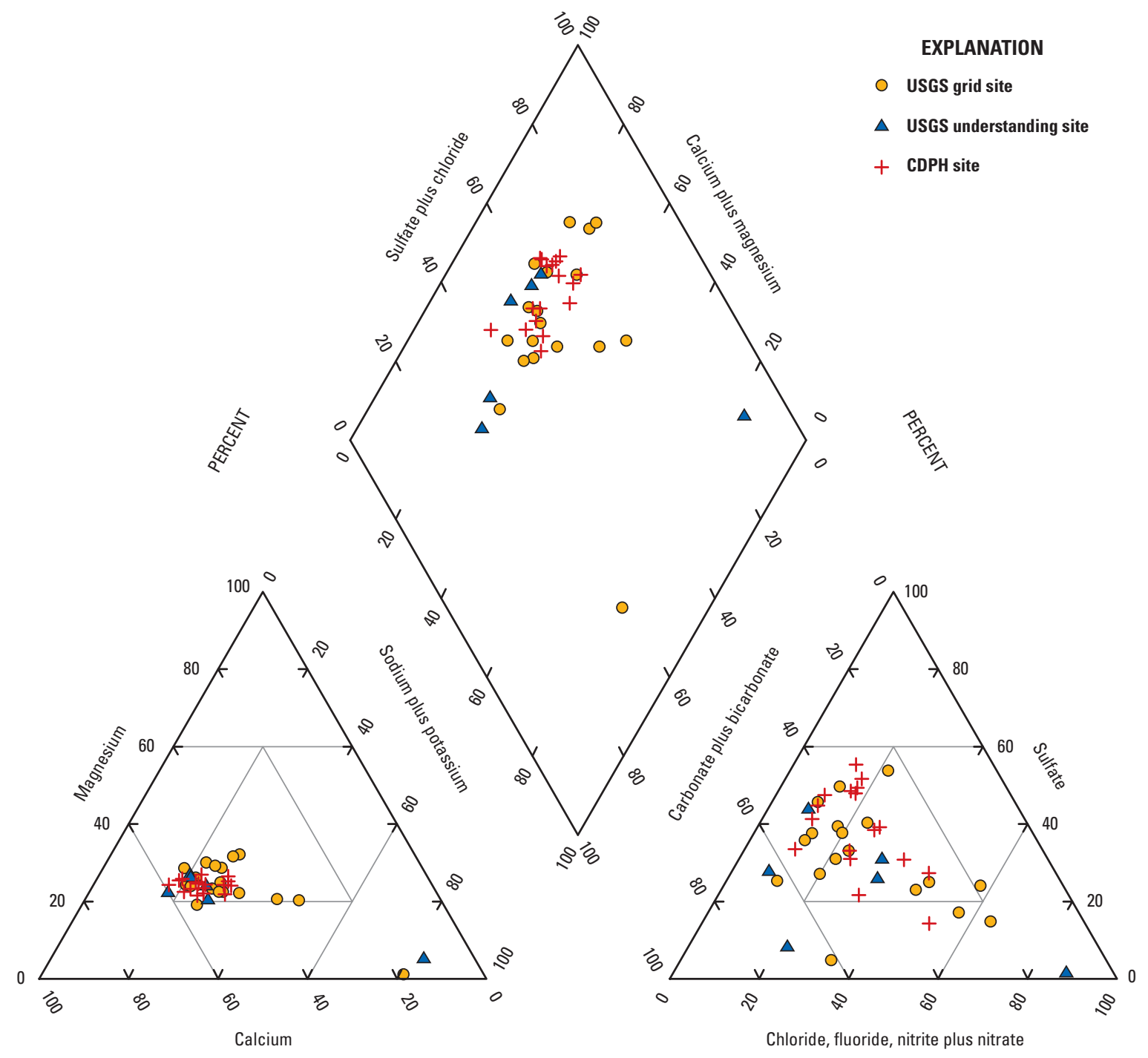

PERCENT

Figure 1-3. Selected inorganic data from U.S. Geological Survey (USGS) sites and California Department of Public Health (CDPH) sites for the Santa Barbara study unit, 2011, California Groundwater Ambient Monitoring and Assessment (GAMA) Priority Basin Project. 
Bicarbonate was the dominant anion in groundwater from 50 percent of the USGS grid sites, followed by chloride at 28 percent and sulfate at 22 percent (fig. 1-3). Calcium was the dominant cation in groundwater from 83 percent of the grid sites, followed by sodium at 17 percent. Sodium accounted for more than 60 percent of the total cations in groundwater from one grid site, and bicarbonate or chloride accounted for more than 60 percent of the total anions in groundwater from three sites. Calcium was the dominant cation in water from all $16 \mathrm{CDPH}$ sites that had available data. The dominant anion in water from the majority of the CDPH wells was different than the USGS grid sites: sulfate was the dominant anion in water from 56 percent of the CDPH sites, followed by bicarbonate at 25 percent and chloride at 19 percent. The greater percentage of sulfate dominant anion mixtures in groundwater from $\mathrm{CDPH}$ sites could be a result of having CDPH sites concentrated in certain areas of the study unit, whereas the USGS grid sites were more evenly distributed spatially.

\section{Radioactivity Data}

The class of radioactive constituents includes constituents whose abundances commonly are measured as activities rather than concentrations. Activity is measured in units of picocuries per liter $(\mathrm{pCi} / \mathrm{L})$, and 1 picocurie equals approximately two atoms decaying per minute. When atoms decay, they release alpha or beta particles, and (or) gamma radiation. Gross alpha radioactivity is a measure of the total activity of non-volatile isotopes decaying by alpha emission. The U.S. Environmental Protection Agency maximum contaminant level (MCL-US) for gross alpha radioactivity $(15 \mathrm{pCi} / \mathrm{L})$ applies to "adjusted" gross alpha radioactivity, which is equal to the measured gross alpha radioactivity minus uranium activity (U.S. Environmental Protection Agency, 2000). Data collected by USGS-GAMA and data compiled in the CDPH database are reported as gross alpha radioactivity without correction for uranium activity. Gross alpha radioactivity is used as a screening tool to determine whether other radioactive constituents must be analyzed. For regulatory purposes, analysis of uranium is only required if gross alpha radioactivity is greater than 15 pCi/L (California State Water Resources Control Board, 2016); therefore, the CDPH database contains substantially more data for gross alpha radioactivity than for uranium. As a result, it is not always possible to calculate adjusted gross alpha radioactivity. For this reason, results for gross alpha radioactivity (that is, without correction for uranium) are the primary data used in the status assessments made by the USGS-GAMA for Priority Basin Project study units. Results for adjusted gross alpha radioactivity also are given in this report for comparison (table 6).

USGS-GAMA reports data for two measurements of gross alpha radioactivity, one counted 72 hours, and one
30 days, after sample collection. Regulatory sampling for gross alpha particle activity permits use of quarterly composite samples (California State Water Resources Control Board, 2016). The composite samples sent by water agencies to laboratories for analysis may be mixtures of four samples collected 9 months, 6 months, 3 months, and a few days before submission. Because of these long holding times for the CDPH data, the USGS-GAMA gross alpha 30-day count data could be more appropriate to use when combining USGSGAMA and CDPH datasets. The 30-day count data were used in this study. Gross alpha particle activity in a groundwater sample can change with time after sample collection as a result of radioactive decay of parent isotopes and ingrowth and subsequent decay of radioactive daughter isotopes (activity can increase or decrease, depending on sample composition and holding time; Arndt, 2010).

\section{References Cited}

Arndt, M.F., 2010, Evaluation of gross alpha and uranium measurements for MCL compliance: Denver, Colo., Water Research Foundation, 299 p.

California State Water Resources Control Board, 2016, California Drinking Water-Related Laws: California State Water Resources Control Board website, accessed September 12, 2016, at http:/www.waterboards.ca.gov/ drinking_water/certlic/drinkingwater/Lawbook.shtml.

Hem, J.D., 1985, Study and interpretation of chemical characteristics of natural waters ( $3 \mathrm{~d}$ ed.): U.S. Geological Survey Water Supply Paper 2254, 263 p., https://pubs.er.usgs.gov/publication/wsp2254.

Parsons, M.S., Hancock, T.C., Kulongoski, J.T., and Belitz, Kenneth, 2014, Status of groundwater quality in the Borrego Valley, Central Desert, and Low-Use Basins of the Mojave and Sonoran Deserts study unit, 2008-2010 California GAMA Priority Basin Project: U.S. Geological Survey Scientific Investigations Report 2014-5001, 88 p., http://dx.doi.org/10.3133/sir20145001.

Piper, A.M., 1944, A graphic procedure in the geochemical interpretation of water-analyses: American Geophysical Union Transactions, v. 25, no. 6, p. 914-928, http://onlinelibrary.wiley.com/doi/10.1029/ TR025i006p00914/abstract.

U.S. Environmental Protection Agency, 2000, National primary drinking water regulations; radionuclides; final rule, accessed February 2012 at http://federalregister.gov/a/00-30421. 
Table 1-1. Grid-cell number and nomenclature for grid sites used in the status assessment, Santa Barbara study unit, 2011, California Groundwater Ambient Monitoring and Assessment (GAMA) Priority Basin Project.

[California Department of Public Health (CDPH) sites were used to provide data for inorganic constituents for grid cells lacking U.S. Geological Survey (USGS) GAMA data. No sites were available to sample by USGS-GAMA for cells 1 and 2, and no recent (January 24, 2008, through January 23, 2011) CDPH data exists for cell 1. Five sites were located in a cell different than the one they were selected to represent. The cells in which these sites are located are identified in parentheses in the first column. Abbreviations: - , no site sampled or selected]

\begin{tabular}{lcc}
\hline \multirow{2}{*}{ Grid-cell number } & \multicolumn{2}{c}{ GAMA site identifier } \\
\cline { 2 - 3 } & USGS-grid site & CDPH-grid site \\
\hline 2 & - & SB-DPH-19 \\
3 & SB-01 & - \\
4 & SB-02 & - \\
$5(7)$ & SB-03 & - \\
6 & SB-05 & - \\
7 & SB-07 & - \\
8 & SB-08 & - \\
$9(8)$ & SB-06 & - \\
$10(9)$ & SB-04 & - \\
$11(12)$ & SB-10 & - \\
12 & SB-11 & - \\
13 & SB-13 & - \\
14 & SB-12 & - \\
15 & SB-09 & - \\
16 & SB-14 & - \\
$17(18)$ & SB-15 & - \\
18 & SB-16 & - \\
19 & SB-18 & - \\
20 & SB-17 & - \\
\hline
\end{tabular}




\section{Appendix 2. Attribution of Potential Explanatory Factors}

\section{Hydrologic Conditions}

The climate at each site was represented by an aridity index (table 2-1). The aridity index is defined by the United Nations Environment Programme (1997) and United Nations Educational, Scientific, and Cultural Organization [UNESCO] (1979) as follows:

$$
\text { aridity index }=\frac{\text { average annual precipitation }}{\text { average annual evapotranspiration }}
$$

Greater values in the index correspond to wetter conditions. Values less than 0.05 are defined as hyper-arid, $0.05-0.20$ as arid, $0.20-0.50$ as semi-arid, $0.50-0.65$ as dry sub-humid, $0.65-1.00$ as humid, and greater than 1.00 as wet. The average annual precipitation for each site was extracted from the PRISM average annual precipitation for 19712000 GIS coverage (PRISM Climate Group, Oregon State University, 2014, United States average annual precipitation, maximum and minimum temperature, 1971-2000, accessed May 27, 2014, at http://prism.oregonstate.edu/). The average annual evapotranspiration for each site was extracted from a GIS coverage modified from Flint and Flint (2007).

Modification of the GIS coverage consisted of calibrating the evapotranspiration values to the measured California Irrigation Management Information System reference evapotranspiration values (California Irrigation Management Information System, 2005; Alan Flint, U.S. Geological Survey California Water Science Center, oral commun., 2009).

\section{Land Use}

Land use for each U.S. Geological Survey (USGS) site (table 2-1) was classified by using an enhanced version of the satellite-derived (30-m pixel resolution), nationwide USGS National Land Cover Dataset (Nakagaki and others, 2007). This dataset has been used in previous national and regional studies relating land use to water quality (Gilliom and others, 2006; Zogorski and others, 2006). The data represent land use during the early 1990s. The imagery is classified into 25 landcover classifications (Nakagaki and Wolock, 2005). These 25 land-cover classifications were condensed into 3 principal land-use categories: urban, agricultural, and natural. Landuse statistics for the study unit, study areas, and areas within a 500-m radius around each site (500-m buffers) were calculated for classified datasets by using ArcGIS. A 500-m radius centered on the site has been shown to be effective at correlating urban land use with the presence of volatile organic compounds (VOCs) for the purposes of statistical characterization (Johnson and Belitz, 2009).

\section{Formerly Leaking Underground Fuel-Tank and Septic-Tank Densities}

Leaking (or formerly leaking) underground fuel tanks (LUFT) generally are associated with urban land use, although they can be in areas classified as natural or agricultural land use. The LUFT density was determined by using a Thiessen polygon approach (Tyler T. Johnson, U.S. Geological Survey, written commun., 2013) and data from the California Environmental Protection Agency (2001). The boundaries of the Thiessen polygon around a particular LUFT are created by bisecting the linear distances between the LUFT and all of the surrounding LUFTs. The density of LUFTs is the number of tanks in the polygon (nearly always one) divided by the area of the polygon in square kilometers. A site is assigned the LUFT density of the Thiessen polygon in which it resides (table 2-1).

Septic tanks generally are associated with dispersed residences and as such, can be in areas classified as natural or agricultural land use in addition to areas classified as urban land use. Septic tank density was determined from housing characteristics data from the 1990 U.S. Census (U.S. Census Bureau, 1990, U.S. Census ftp site, accessed May 27, 2014, at ftp://ftp2.census.gov/census_1990). The density of septic tanks in each housing census block was calculated from the number of tanks and the block area. The density of septic tanks around each site was then calculated from the area-weighted mean of the block densities for blocks within a 500-m buffer around the site (table 2-1).

\section{Well Construction}

Well-construction data were obtained primarily from drillers' logs filed with the California Department of Water Resources (CDWR). In some cases, well-construction data were obtained from ancillary records of site owners or the USGS National Water Information System database. Well depths and depths to the top and bottom of the screened or open interval for USGS grid wells are listed in table 2-1. Wellidentification verification procedures are described by Davis and others (2013). Well-construction data were not available for wells in the CDPH database. 


\section{Groundwater-Age Classification}

Groundwater-dating techniques indicate the time since the groundwater was last in contact with the atmosphere. Techniques used to estimate groundwater residence times, or 'age,' include those based on tritium (for example, Tolstikhin and Kamensky, 1969; Torgersen and others, 1979) and ${ }^{14} \mathrm{C}$ activities (for example, Vogel and Ehhalt, 1963; Plummer and others, 1993). Tritium concentrations, uncorrected ${ }^{14} \mathrm{C}$ age, and age classifications for Santa Barbara grid- and understandingsite samples for the Santa Barbara study unit are reported in table $2-2$.

Tritium $\left({ }^{3} \mathrm{H}\right)$ is a short-lived radioactive isotope of hydrogen that has a half-life of 12.32 years (Lucas and Unterweger, 2000). Tritium is produced naturally in the atmosphere by the interaction of cosmogenic radiation with nitrogen (Craig and Lal, 1961), by aboveground nuclear weapons testing, and by the operation of nuclear reactors. Beginning in about 1952, aboveground nuclear explosions caused a large increase in tritium values in precipitation that peaked in 1963 at values over 1,000 tritium units (TU) in the northern hemisphere (Michel, 1989). Tritium enters the hydrological cycle following oxidation to tritiated water. Tritium values in precipitation under natural conditions (prior to nuclear testing) in the Santa Barbara study unit were about 2 to 4 TU (updated values from Michel, 1989). On the west coast, most of the storms are oceanic in origin, so the water from these storms mostly comes from exchange with surface ocean water, which has relatively low tritium concentrations (Michel, 1989). Radioactive decay of tritium in water with a tritium value of $4 \mathrm{TU}$ in 1950 would result in a tritium value of 0.2 TU in 2011. Previous investigations have used a range of tritium values from 0.3 to 1.0 tritium unit (TU) as thresholds for indicating presence of water that has exchanged with the atmosphere since 1952 (Michel, 1989; Plummer and others, 1993; Michel and Schroeder, 1994; Clark and Fritz, 1997; Manning and others, 2005). For samples collected for the Santa Barbara study unit in 2011, groundwater that had tritium values less than 0.3 TU were defined as "pre-modern" (recharged before 1952); tritium values greater than $0.3 \mathrm{TU}$ indicated the presence of "modern" groundwater (recharged since 1952; table 2-2). By using a tritium value of $0.3 \mathrm{TU}$ for the threshold for this study, the age classification scheme allows for samples with a slightly larger fraction of premodern groundwater to be classified as "mixed" (containing components recharged before and after 1952) than if a higher threshold were used. A higher threshold for tritium would result in fewer samples classified as mixed than classified as pre-modern, when ${ }^{14} \mathrm{C}$ data indicate that the samples were mixed with modern groundwater.

Carbon-14 $\left({ }^{14} \mathrm{C}\right)$ is a widely used chronometer based on the radiocarbon content of organic and inorganic carbon. Dissolved inorganic carbonate species, carbonic acid, bicarbonate, and carbonate, typically are used for ${ }^{14} \mathrm{C}$ dating of groundwater. Carbon-14 is formed in the atmosphere by the interaction of cosmic-ray neutrons with nitrogen and, to a lesser degree, with oxygen and carbon. Carbon-14 is incorporated into carbon dioxide and mixed throughout the atmosphere, dissolved in precipitation, and incorporated into the hydrologic cycle. Carbon-14 activity in groundwater, expressed as percent modern carbon (pmc), reflects the time since groundwater was last exposed to the atmospheric ${ }^{14} \mathrm{C}$ source. Carbon- 14 has a half-life of 5,730 years, which can be used to estimate groundwater ages ranging from 1,000 to less than 30,000 years before present (Clark and Fritz, 1997).

Carbon-14 data can be reported in units of percent modern $(\mathrm{pM})$ or in the units of percent modern carbon (pmc). The ${ }^{14} \mathrm{C}$ data for the Santa Barbara study unit by Davis and others (2013) are given in pM units, as reported by the analyzing laboratory, and have been normalized for carbon isotopic fractionation on the basis of a stable isotope composition of carbon $\left(\delta^{13} \mathrm{C}\right)$ of -25 per mil (parts per thousand). The non-normalized ${ }^{14} \mathrm{C}$ data in pmc units are used in this report. Data were converted from $\mathrm{pM}$ to pmc by using this equation, derived from Plummer and others (2004):

$$
p m c=\frac{p M\left(1+\frac{\delta^{13} C}{1,000}\right)^{2}}{0.975^{2}}
$$

where

$$
\begin{gathered}
\text { pM is the }{ }^{14} \mathrm{C} \text { value, in units of } \mathrm{pM} \text {, and } \\
\delta^{13} \mathrm{C} \quad \text { is the measured }{ }^{13} \mathrm{C} \text { composition, in units of } \\
\text { per mil. }
\end{gathered}
$$

The ${ }^{14} \mathrm{C}$ age (residence time) is calculated on the basis of the decrease in ${ }^{14} \mathrm{C}$ activity that has resulted from radioactive decay since groundwater recharge relative to an assumed initial ${ }^{14} \mathrm{C}$ concentration (Clarke and Fritz, 1997). A mean initial ${ }^{14} \mathrm{C}$ activity of $100 \mathrm{pmc}$ was assumed for this study, with estimated errors for calculated groundwater ages of as much as plus or minus 20 percent. Calculated ${ }^{14} \mathrm{C}$ ages in this study are referred to as "uncorrected" because they have not been adjusted to consider exchanges with sedimentary sources of carbon (Fontes and Garnier, 1979). Groundwater with a ${ }^{14} \mathrm{C}$ activity greater than $88 \mathrm{pmc}$ is reported as having an age of less than 1,000 years; no attempt was made to refine ${ }^{14} \mathrm{C}$ ages of less than 1,000 years (table 2-2). Measured values of percent modern carbon can be greater than $100 \mathrm{pmc}$ because the definition of the ${ }^{14} \mathrm{C}$ activity in "modern" carbon does not include the excess ${ }^{14} \mathrm{C}$ produced in the atmosphere by aboveground nuclear weapons testing. For the Santa Barbara study unit, ${ }^{14} \mathrm{C}$ activity less than 88 pmc was defined as indicative of the presence of groundwater recharged before 1952. The threshold value of 88 pmc was selected, because all but one groundwater sample with tritium greater than $1 \mathrm{TU}$ (more than three times the threshold for distinguishing between pre-modern and mixed groundwater) also had ${ }^{14} \mathrm{C}$ activity greater than $88 \mathrm{pmc}$. 


\section{Geochemical Condition}

Geochemical conditions tabulated as potential explanatory factors in this report include oxidation-reduction (redox) characteristics, dissolved oxygen, $\mathrm{pH}$, and ratio of iron species. The geochemical data for each site are shown in table 2-3. Redox conditions influence the mobility of many organic and inorganic constituents (McMahon and Chapelle, 2008). Redox conditions along groundwater-flow paths commonly proceed along a well-documented sequence of terminal electron acceptor processes (TEAP); one TEAP typically dominates at a particular time and place in the aquifer (Chapelle and others, 1995; Chapelle, 2001). The predominant TEAPs are oxygen-reduction, nitrate-reduction, manganese-reduction, iron-reduction, sulfate-reduction, and methanogenesis. The presence of redox-sensitive chemical species indicating more than one TEAP could indicate mixed water from different redox zones upgradient of the site, a well screened across more than one redox zone, or spatial heterogeneity in microbial activity in the aquifer. This TEAP sequence is the order predicted from equilibrium thermodynamics and corresponds to progressively decreasing oxidation-reduction potentials. Different redox elements (for example, iron, manganese, and sulfur) tend not to reach overall equilibrium in most natural water systems (Lindberg and Runnells, 1984); therefore, a single redox measurement usually cannot represent the system, further complicating the assessment of redox conditions.

In this report, redox conditions were represented by redox class (oxic, anoxic, or mixed) and by reduction processes (table 2-3). Redox conditions and processes were classified according to the TEAPs inferred from dissolved oxygen (DO), nitrate, manganese, iron, and sulfate concentrations by using a modified version of the classification scheme of McMahon and Chapelle (2008) used by an automated workbook program (Jurgens and others, 2009). Other geochemical conditions related to redox processes, including DO concentrations, $\mathrm{pH}$ values, and ratios of iron species, were also presented in table 2-3. Ratios of iron species were not calculated for samples that had total iron concentrations of less than $10 \mu \mathrm{g} / \mathrm{L}$, which is five times the reporting level.

\section{References Cited}

California Environmental Protection Agency, 2001, Geographic Environmental Information Management System GeoTracker (GEIMS) Leaking Underground Fuel/ Storage Tank database (LUFT) [digital data]: Sacramento, Calif., California Environmental Protection Agency, State Water Resources Control Board, Division of Water Quality; data available online at http://geotracker.waterboards. ca.gov/data_download.asp.
California Irrigation Management Information System, 2005, CIMIS Reference Evapotranspiration Zones, accessed April 22, 2015, at http://wwwcimis.water.ca.gov/App_ Themes/images/etozonemap.jpg.

Chapelle, F.H., 2000, Ground-water microbiology and geochemistry (2d Ed): New York, John Wiley and Sons, Inc., $468 \mathrm{p}$.

Chapelle, F.H., McMahon, P.B., Dubrovsky, N.M., Fuji, R.F., Oaksford, E.T., and Vroblesky, D.A., 1995, Deducing the distribution of terminal electron-accepting processes in hydrologically diverse groundwater systems: Water Resources Research, v. 31, no. 2, p. 359-371, http://dx.doi.org/10.1029/94WR02525.

Clark, I.D., and Fritz, Peter, 1997, Environmental isotopes in hydrogeology: Boca Raton, Florida, CRC Press LLC, 342 p.

Craig, Harmon, and Lal, Devendra, 1961, The production rate of natural tritium: Tellus, v. 13, no. 1, p. 85-105, http://dx.doi.org/10.1111/j.2153-3490.1961.tb00068.x.

Davis, T.A., Kulongoski, J.T., and Belitz, Kenneth, 2013, Groundwater-quality data in Santa Barbara study unit, 2011-Results from the California GAMA Program: U.S. Geological Survey Data Series 742, 72 p., https://pubs.er.usgs.gov/publication/ds742.

Flint, A.L., and Flint, L.E., 2007, Application of the basin characterization model to estimate in-place recharge and runoff potential in the Basin and Range carbonate-rock aquifer system, White Pine County, Nevada, and adjacent areas in Nevada and Utah: U.S. Geological Survey Scientific Investigations Report 2007-5099, 21 p., https://pubs.er.usgs.gov/publication/sir20075099.

Fontes, J-C., and Garnier, J-M., 1979, Determination of the initial ${ }^{14} \mathrm{C}$ activity of the total dissolved carbon-A review of the existing models and a new approach: Water Resources Research, v. 15, no. 2, p. 399-413, http://dx.doi.org/10.1029/WR015i002p00399.

Gilliom, R.J., Barbash, J.E., Crawford, C.G., Hamilton, P.A., Martin, J.D., Nakagaki, Naomi, Nowell, L.H., Scott, J.C., Stackelberg, P.E., Thelin, G.P., and Wolock, D.M., 2006, The quality of our nation's waters-Pesticides in the nation's streams and ground water, 1992-2001: U.S. Geological Survey Circular 1291, 173 p., https://pubs.er.usgs.gov/publication/cir1291.

Johnson, T.D., and Belitz, Kenneth, 2009, Assigning land use to supply wells for the statistical characterization of regional groundwater quality - Correlating urban land use and VOC occurrence: Journal of Hydrology, v. 370, no. 1-4, p. 100-108, http://dx.doi.org/10.1016/j.jhydrol.2009.02.056. 
Jurgens, B.C., McMahon, P.B., Chapelle, F.H., and Eberts, S.M., 2009, An Excel workbook for identifying redox processes in ground water: U.S. Geological Survey Open-File Report 2009-1004, 8 p.,

https://pubs.er.usgs.gov/publication/ofr20091004.

Lindberg, R.D., and Runnels, D.D., 1984, Ground water redox reactions-An analysis of equilibrium state applied to Eh measurements and geochemical modeling: Science, v. 225 , no. 4665 , p. $925-927$, http://dx.doi.org/10.1126/science.225.4665.925.

Lucas, L.L., and Unterweger, M.P., 2000, Comprehensive review and critical evaluation of the half-life of tritium: Journal of Research of the National Institute of Standards and Technology, v. 105, no. 4, p. 541-549, http://nvlpubs.nist.gov/nistpubs/jres/105/4/j54luc2.pdf.

McMahon, P.B., and Chapelle, F.H., 2008, Redox processes and water quality of selected principal aquifer systems: Ground Water, v. 46, no. 2, p. 259-271, http://dx.doi.org/10.1111/j.1745-6584.2007.00385.x.

Manning, A.H., Solomon, D.K., and Thiros, S.A., 2005 ${ }^{3} \mathrm{H} /{ }^{3} \mathrm{He}$ age data in assessing the susceptibility of wells to contamination: Ground Water, v. 43, no. 3, p. 353-367, http://dx.doi.org/10.1111/j.1745-6584.2005.0028.x.

Michel, R.L., 1989, Tritium deposition in the continental United States, 1953-83: U.S. Geological Survey WaterResources Investigations Report 89-4072, 46 p., https://pubs.er.usgs.gov/publication/wri894072.

Michel, R.L., and Schroeder, R.A., 1994, Use of long-term tritium records from the Colorado River to determine timescales for hydrologic processes associated with irrigation in the Imperial Valley, California: Applied Geochemistry, v. 9, no. 4, p. 387-401, http://dx.doi.org/10.1016/0883-2927(94)90061-2.

Nakagaki, Naomi, and Wolock, D.M., 2005, Estimation of agricultural pesticide use in drainage basins using land cover maps and county pesticide data: U.S. Geological Survey Open-File Report 2005-1188, 56 p., https://pubs.er.usgs.gov/publication/ofr20051188.

Nakagaki, Naomi, Price, C.V., Falcone, J.A., Hitt, K.J., and Ruddy, B.C., 2007, Enhanced National Land Cover Data 1992 (NLCDe 92): U.S. Geological Survey Raster digital data, available online at http://water.usgs.gov/lookup/getspatial?nlcde92.
Plummer, L.N., Michel, R.L., Thurman, E.M., and Glynn, P.D., 1993, Environmental tracers for age-dating young ground water, in Alley, W.M., ed., Regional groundwater quality: New York, Van Nostrand Reinhold, p. $255-294$.

Plummer, L.N., Bexfield, L.M., Anderholm, S.K., Sanford, W.E., and Busenberg, Eurybiades, 2004, Geochemical characterization of ground-water flow in the Santa Fe Group aquifer system, Middle Rio Grande Basin, New Mexico: U.S. Geological Survey Water-Resources Investigations Report 2003-4131, 395 p., http://pubs.er.usgs.gov/publication/wri034131.

Tolstikhin, I.N., and Kamensky, I.L., 1969, Determination of groundwater ages by the T-3He method: Geochemistry International, v. 6, p. 810-811.

Torgersen, T., Jenkins, W.J. and Clarke, W.B., 1979, The tritium/helium-3 method in hydrology: IAEA-SM-228, v. 49, p. $917-930$.

United Nations Educational, Scientific, and Cultural Organization (UNESCO), 1979, Map of the world distribution of arid regions - Explanatory note. MAB Technical Notes, v. 7, 42 p., http://unesdoc.unesco.org/ images/0003/000326/032661eo.pdf.

United Nations Environment Programme, 1997, World Atlas of Desertification, 2d ed.: Arnold, London, 182 p.

Vogel, J.C., and Ehhalt, D., 1963, The use of the carbon isotopes in groundwater studies, in Radioisotopes in hydrology, Proceedings of the symposium on the application of radioisotopes in hydrology: Tokyo, International Atomic Energy Agency, p. 383-395, http://www.iaea.org/inis/ collection/NCLCollectionStore/_Public/44/053/44053949. pdf.

Zogorski, J.S., Carter, J.M., Ivahnenko, Tamara, Lapham, W.W., Moran, M.J., Rowe, B.L., Squillace, P.J., and Toccalino, P.L., 2006, Volatile organic compounds in the Nation's ground water and drinking-water supply wells: U.S. Geological Survey Circular 1292, 101 p., https://pubs.er.usgs.gov/publication/cir1292. 
Table 2-1. Well construction information, land-use data, and other ancillary data for sites, Santa Barbara study unit, 2011, California Groundwater Ambient Monitoring and Assessment (GAMA) Priority Basin Project.

[Abbreviations: ft, feet; LSD, land surface datum; LUFT, leaking (or formerly leaking) underground fuel tank; m, meter; na, not available; tanks/km², tanks per square kilometer]

\begin{tabular}{|c|c|c|c|c|c|c|c|c|c|}
\hline \multirow{2}{*}{$\begin{array}{c}\text { GAMA } \\
\text { site } \\
\text { identifier }\end{array}$} & \multicolumn{3}{|c|}{ Well construction information } & \multicolumn{3}{|c|}{ Land use within $500 \mathrm{~m}$ of site ${ }^{1}$} & \multirow{2}{*}{$\begin{array}{c}\text { LUFT } \\
\text { density }{ }^{2} \\
\text { (tanks/km²) }\end{array}$} & \multirow{2}{*}{$\begin{array}{c}\text { Septic-tank } \\
\text { density }{ }^{3} \\
\left(\operatorname{tanks} / \mathbf{k m}^{2}\right)\end{array}$} & \multirow{2}{*}{$\begin{array}{c}\text { Aridity } \\
\text { index }{ }^{4} \\
\text { (dimensionless }\end{array}$} \\
\hline & $\begin{array}{c}\text { Well depth } \\
\text { (ft below LSD) }\end{array}$ & $\begin{array}{l}\text { Top of perforations } \\
\text { (ft below LSD) }\end{array}$ & $\begin{array}{c}\text { Bottom of perforations } \\
\text { (ft below LSD) }\end{array}$ & $\begin{array}{l}\text { Agricultural } \\
\text { (percent) }\end{array}$ & $\begin{array}{c}\text { Natural } \\
\text { (percent) }\end{array}$ & $\begin{array}{c}\text { Urban } \\
\text { (percent) }\end{array}$ & & & \\
\hline \multicolumn{10}{|c|}{ Santa Barbara study-unit grid sites } \\
\hline SB-01 & 150 & 110 & 150 & 0 & 43 & 57 & 6.14 & 6.32 & 0.31 \\
\hline SB-02 & 820 & 210 & 820 & 0.2 & 21 & 79 & 5.08 & 0 & 0.31 \\
\hline SB-03 & 450 & 250 & 450 & 0.5 & 1.3 & 98 & 0.54 & 6.27 & 0.32 \\
\hline SB-04 & 680 & 180 & 680 & 1.1 & 3.0 & 96 & 0.63 & 2.05 & 0.31 \\
\hline SB-05 & 410 & 255 & 410 & 0 & 38 & 62 & 1.01 & 22.9 & 0.32 \\
\hline SB-06 & 630 & 350 & 630 & 0 & 13 & 87 & 0.47 & 18.9 & 0.34 \\
\hline SB-07 & 427 & 215 & 427 & 0 & 10 & 90 & 1.51 & 35.6 & 0.34 \\
\hline SB-08 & 583 & 203 & 583 & 0 & 13 & 87 & 2.81 & 25.2 & 0.33 \\
\hline SB-09 & 350 & 140 & 350 & 0 & 7.9 & 92 & 0.01 & 11.7 & 0.38 \\
\hline SB-10 & 145 & 55 & 145 & 0 & 22 & 78 & 1.01 & 8.39 & 0.31 \\
\hline SB-11 & 206 & 100 & 206 & 0 & 12 & 88 & 1.01 & 20.3 & 0.31 \\
\hline SB-12 & 280 & 100 & 280 & 0 & 0 & 100 & 1.03 & 12.7 & 0.36 \\
\hline SB-13 & 460 & 170 & 460 & 1.5 & 50 & 49 & 0.45 & 17.7 & 0.31 \\
\hline SB-14 & 975 & 195 & 975 & 2.9 & 26 & 71 & 0.17 & 25.4 & 0.37 \\
\hline SB-15 & 938 & 317 & 938 & 11 & 7.0 & 82 & 0.04 & 19.8 & 0.29 \\
\hline SB-16 & 1,230 & 310 & 1,230 & 29 & 10 & 61 & 0.07 & 24.3 & 0.30 \\
\hline SB-17 & 250 & na & na & 65 & 35 & 0.2 & 0.01 & 5.04 & 0.31 \\
\hline SB-18 & 295 & 85 & 295 & 55 & 44 & 0.5 & 0.01 & 4.07 & 0.36 \\
\hline \multicolumn{10}{|c|}{ Santa Barbara study-unit understanding sites } \\
\hline SBU-01 & 1,065 & 549 & 1,065 & 0 & 5.7 & 94 & 0.56 & 3.00 & 0.32 \\
\hline SBU-02 & 780 & 760 & 780 & 0.1 & 14 & 86 & 27.3 & 0.10 & 0.33 \\
\hline SBU-03 & 670 & 650 & 670 & 0.1 & 14 & 86 & 27.3 & 0.10 & 0.33 \\
\hline SBU-04 & 440 & 420 & 440 & 0.1 & 14 & 86 & 27.3 & 0.10 & 0.33 \\
\hline SBU-05 & 220 & 200 & 220 & 0.1 & 14 & 86 & 27.3 & 0.10 & 0.33 \\
\hline SBU-06 & 464 & 280 & 464 & 0.5 & 7.7 & 92 & 2.02 & 3.60 & 0.34 \\
\hline
\end{tabular}

${ }^{1}$ Land-use percentages within 500-m radius of site (Nakagaki and others, 2007; Johnson and Belitz, 2009).

${ }^{2}$ Leaking (or formerly leaking) underground fuel-tank density within 500-m radius of site (California Environmental Protection Agency, 2001).

${ }^{3}$ Septic-tank density within 500-m radius of site (U.S. Census Bureau, 1990, U.S. Census Bureau ftp site, accessed May 27, 2014, at ftp://ftp2.census.gov/census_1990).

${ }^{4}$ Aridity index is average annual precipitation divided by average annual potential evapotranspiration (United Nations Educational, Scientific, and Cultural Organization, 1979). 
Table 2-2. Tritium, ${ }^{14} \mathrm{C}$ data, and groundwater age classifications, Santa Barbara study unit, 2011, California Groundwater Ambient Monitoring and Assessment (GAMA) Priority Basin Project.

[Groundwater age classifications were based on tritium and carbon-14 data. Pre-modern (recharged before 1952): tritium less than 0.3 tritium unit (TU). Mixed (containing components recharged before and after 1952): tritium greater than $0.3 \mathrm{TU}$ and percent modern carbon less than 88. Modern (recharged after 1952): tritium greater than $0.3 \mathrm{TU}$ and percent modern carbon greater than 88. Abbreviations: USGS, U.S. Geological Survey; ${ }^{14} \mathrm{C}$, carbon- $14 ;<$, less than; - , not detected]

\begin{tabular}{ccccl}
\hline $\begin{array}{c}\text { GAMA } \\
\text { site } \\
\text { identifier }\end{array}$ & $\begin{array}{c}\text { Tritium } \\
\text { (TU) }\end{array}$ & $\begin{array}{c}\text { Percent } \\
\text { modern carbon } \\
\text { (pmc) }\end{array}$ & $\begin{array}{c}\text { Uncorrected } \\
{ }^{14} \text { C age } \\
\text { (years) }\end{array}$ & \multicolumn{1}{c}{$\begin{array}{c}\text { Age } \\
\text { classification }\end{array}$} \\
\hline \multicolumn{5}{c}{ Santa Barbara study-unit grid sites } \\
\hline SB-01 & - & 47.6 & 5,900 & Pre-modern \\
SB-02 & 0.12 & 79.0 & 1,840 & Pre-modern \\
SB-03 & 0.50 & 84.3 & 1,310 & Mixed \\
SB-04 & 1.06 & 71.4 & 2,640 & Mixed \\
SB-05 & 0.43 & 84.0 & 1,340 & Mixed \\
SB-06 & - & 44.1 & 6,520 & Pre-modern \\
SB-07 & 0.40 & 85.4 & 1,210 & Mixed \\
SB-08 & 0.25 & 70.9 & 2,710 & Pre-modern \\
SB-09 & 0.40 & 87.5 & 1,010 & Mixed \\
SB-10 & 1.22 & 88.8 & $<1,000$ & Modern \\
SB-11 & 1.44 & 98.4 & $<1,000$ & Modern \\
SB-12 & 1.66 & 109.7 & $<1,000$ & Modern \\
SB-13 & 0.37 & 77.9 & 1,940 & Mixed \\
SB-14 & - & 48.9 & 5,690 & Pre-modern \\
SB-15 & - & 57.9 & 4,330 & Pre-modern \\
SB-16 & 0.28 & 68.1 & 3,030 & Pre-modern \\
SB-17 & 1.56 & 94.3 & $<1,000$ & Modern \\
SB-18 & 0.59 & 79.4 & 1,790 & Mixed \\
\hline & Santa Barbara study-unit understanding & sites ${ }^{1}$ \\
\hline SBU-01 & - & 73.4 & 2,430 & Pre-modern \\
SBU-03 & - & 58.4 & 4,260 & Pre-modern \\
SBU-04 & 0.18 & 74.2 & 2,340 & Pre-modern \\
SBU-06 & 0.31 & 86.8 & 1,080 & Mixed \\
\hline I & & & & \\
\hline
\end{tabular}

${ }^{1}$ Results of the age classifications for USGS understanding sites SBU-02 and SBU-05 were omitted from this table and are not included in the status assessment, because of a possible mix-up of the carbon isotope samples for these sites. 
Table 2-3. Dissolved oxygen concentration, $\mathrm{pH}$, ratio of oxidized and reduced iron, and oxidation-reduction classification Santa Barbara study unit, 2011, California Groundwater Ambient Monitoring and Assessment (GAMA) Priority Basin Project.

[Oxidation reduction classifications determined using measured dissolved oxygen, nitrate, manganese, iron, and sulfate concentrations and the Jurgens and others (2009) Excel $^{\circledR}$ workbook, based on the framework described by McMahon and Chapelle (2008). Chemical species: Fe ${ }^{2+}$, iron with +2 oxidation state; $\mathrm{Fe}^{3+}$, iron with +3 oxidation state; $\mathrm{Mn}^{4+}$, manganese with +4 oxidation state; $\mathrm{NO}_{3}^{-}$, nitrate; $\mathrm{SO}_{4}{ }^{2-}$, sulfate. Abbreviations: $\mathrm{mg} / \mathrm{L}$, milligrams per liter; na, not available; - , not detected or, for ratio of iron species, total iron concentration too low (less than 5 times the reporting level) to measure ratio]

\begin{tabular}{|c|c|c|c|c|c|}
\hline $\begin{array}{l}\text { GAMA site } \\
\text { identifier }\end{array}$ & $\begin{array}{l}\text { Dissolved oxygen } \\
\text { (mg/L) }\end{array}$ & $\mathrm{pH}$ & $\mathrm{Fe}^{3+} / \mathrm{Fe}^{2+}$ & $\begin{array}{l}\text { Oxidation-reduction } \\
\text { classification }\end{array}$ & $\begin{array}{l}\text { Anoxic reduction } \\
\text { process(es) }\end{array}$ \\
\hline \multicolumn{6}{|c|}{ Santa Barbara study-unit grid sites } \\
\hline SB-01 & 0.2 & 7.0 & 0.02 & Anoxic & $\mathrm{Fe}^{3+}$ and (or) $\mathrm{SO}_{4}^{2-}$ reduction \\
\hline SB-02 & 0.2 & 7.1 & 0.02 & Anoxic & $\mathrm{Fe}^{3+}$ and (or) $\mathrm{SO}_{4}^{2-}$ reduction \\
\hline SB-03 & 0.3 & 7.1 & 0.10 & Anoxic & $\mathrm{Fe}^{3+}$ and (or) $\mathrm{SO}_{4}^{2-}$ reduction \\
\hline SB-04 & 0.7 & 6.9 & 0.88 & Oxic & none \\
\hline SB-05 & 5.1 & 7.0 & - & Oxic & none \\
\hline SB-06 & 0.2 & 7.2 & 0.02 & Anoxic & $\mathrm{Fe}^{3+}$ and (or) $\mathrm{SO}_{4}^{2-}$ reduction \\
\hline SB-07 & 3.3 & 6.8 & - & Oxic & none \\
\hline SB-08 & 0.2 & 6.6 & - & Anoxic & $\mathrm{NO}^{3-}$ reduction \\
\hline SB-09 & 3.3 & 6.4 & - & Oxic & none \\
\hline SB-10 & 0.3 & 6.3 & - & Anoxic & $\mathrm{NO}^{3-}$ and $\mathrm{Mn}^{4+}$ reduction \\
\hline SB-11 & 3.1 & 6.9 & - & Oxic & none \\
\hline SB-12 & 3.8 & 6.4 & - & Oxic & none \\
\hline SB-13 & 3.2 & 6.7 & 0.47 & Mixed & $\mathrm{Fe}^{3+}$ and (or) $\mathrm{SO}_{4}^{2-}$ reduction \\
\hline SB-14 & 0.2 & 7.5 & 0.15 & Anoxic & $\mathrm{Fe}^{3+}$ and (or) $\mathrm{SO}_{4}^{2-}$ reduction \\
\hline SB-15 & 0.4 & 7.2 & 1 & Anoxic & $\mathrm{NO}^{3-}$ and $\mathrm{Mn}^{4+}$ reduction \\
\hline SB-16 & 0.6 & 7.2 & 0.88 & Mixed & $\mathrm{Mn}^{4+}$ reduction \\
\hline SB-17 & 4.7 & 7.0 & - & Oxic & none \\
\hline SB-18 & 2.3 & 7.1 & - & Oxic & none \\
\hline SB-DPH-19 & na & 6.9 & na & Indeterminant & none \\
\hline \multicolumn{6}{|c|}{ Santa Barbara study-unit understanding sites } \\
\hline SBU-01 & 0.2 & 7.4 & 0.04 & Anoxic & $\mathrm{Fe}^{3+}$ and (or) $\mathrm{SO}_{4}^{2-}$ reduction \\
\hline SBU-02 & 0.2 & 7.6 & - & Suboxic & none \\
\hline SBU-03 & - & 7.8 & - & Anoxic & $\mathrm{Mn}^{4+}$ reduction \\
\hline SBU-04 & 0.7 & 7.2 & - & Oxic & none \\
\hline SBU-05 & 1.8 & 7.0 & - & Oxic & none \\
\hline SBU-06 & 0.4 & 7.3 & 0.04 & Anoxic & $\mathrm{Fe}^{3+}$ and (or) $\mathrm{SO}_{4}^{2-}$ reduction \\
\hline
\end{tabular}




\section{Appendix 3. Additional Water-Quality Data}

\section{Results for Dissolved Noble Gases and Modeled Results for Isotopic Analyses of Boron and Recharge Temperatures Strontium}

Data for noble gases were not available in time for inclusion in the report by Davis and others (2013). Results for analysis of dissolved noble gases (argon, helium, krypton, neon, and xenon) and modeled recharge temperatures are reported in table 3-1. A brief discussion of the collection procedures and the associated data are given here.

Samples were collected from 23 sites in the Santa Barbara study unit for analysis of dissolved noble gases (table 3-1). Dissolved noble gases were collected in $3 / 8$-inchdiameter copper tubes by using reinforced nylon tubing connected to the hose bib at the wellhead. Groundwater was flushed through the tubing to dislodge bubbles before flow was restricted with a back pressure valve. Clamps on either end of the copper tube then were tightened, trapping a sample of groundwater for analysis (Kulongoski and Hilton, 2011). Samples were analyzed by the Lawrence Livermore National Laboratory by using methods described by Moran and others (2002) and Eaton and others (2003).

Gases dissolve in water that is in contact with the atmosphere, and the solubilities of the different gas species vary with temperature. Concentrations of noble gases can be used to estimate the conditions of groundwater recharge, particularly the temperature of the water at the time of recharge. Recharge temperatures for 22 samples were calculated from dissolved neon, argon, krypton, and xenon data by using methods described by AeschbachHertig and others (1999; table 3-1). The only modeled recharge temperatures accepted were those for which the probability was greater than 1 percent that the sum of the squared deviations between the modeled and the measured concentrations (weighted with the experimental 1 -sigma errors) was equal to or greater than the observed value (Aeschbach-Hertig and others, 2000). The recharge temperature that had the greatest probability for each sample is given in this report.
Data for boron and strontium isotopes were not available in time for inclusion in the report by Davis and others (2013). Results for the stable isotope composition of boron $\left(\delta^{11} \mathrm{~B}\right)$ and isotopic ratio of strontium $\left({ }^{87} \mathrm{Sr} /{ }^{86} \mathrm{Sr}\right)$ dissolved in water are reported in table 3-2. A brief discussion of the collection procedures and the associated data are given here.

Samples were collected from 24 sites in the Santa Barbara study unit for analyses of boron and strontium isotopes (table 3-2). Samples were filtered into one 250-mL polyethylene bottle and secured with electrical tape to prevent leakage and evaporation. Samples were analyzed by the U.S. Geological Survey National Research Program Metals Isotope Research Laboratory using methods described by Vengosh and others (1989), Bullen and others (1996), and Dwyer and Vengosh (2008).

Boron isotopes can be useful in distinguishing the sources of boron in groundwater. Natural sources include igneous rocks, evaporate minerals, seawater, and geothermal water. Boron isotope variations have been shown to reflect mixing in the regional groundwater and the boron isotope fractionalization following boron removal by adsorption onto clays. As a result, boron isotopes are a useful tracer in groundwater systems in which the role of clay and minerals can be clearly identified (as a tracer for anthropogenic boron or as a tracer for seawater contamination, for example; U.S. Geological Survey, 2004). The ratio of ${ }^{87} \mathrm{Sr} /{ }^{86} \mathrm{Sr}$ reflects the amounts of strontium (and other inorganic constituents) the aquifer materials are contributing to the groundwater system. In regions that have diverse geology, strontium isotope ratios can aid in identifying groundwater-flow paths. 


\section{References Cited}

Aeschbach-Hertig, W., Peeters, F., Beyerle, U., and Kipfer, R., 1999, Interpretation of dissolved atmospheric noble gases in natural waters: Water Resources Research, v. 35, no. 9, p. 2779-2792, http://dx.doi.org/10.1029/1999WR900130.

Aeschbach-Hertig, W., Peeters, F., Beyerle, U., and Kipfer, R., 2000, Paleotemperature reconstruction from noble gases in ground water taking into account equilibration with entrapped air: Nature, v. 405, p. 1040-1044, http://www. nature.com/nature/journal/v405/n6790/full/4051040a0.html.

Bullen, T.D., Krabbenhoft, D.P., and Kendall, Carol, 1996, Kinetic and mineralogic controls on the evolution of groundwater chemistry and ${ }^{87} \mathrm{Sr} /{ }^{86} \mathrm{Sr}$ in a sandy silicate aquifer, northern Wisconsin, USA: Geochimica et Cosmochimica Acta, v. 60, no. 10, p. 1807-1821, http://dx.doi.org/10.1016/0016-7037(96)00052-X.

Coplen, T.B., Hopple, J.A., Bohlke, J.K., Peiser, H.S., Rieder, S.E., Krouse, H.R., Rosman, K.J.R., Ding, T., Vocke, R.D., Jr., Revesz, K.M., Lamberty, A., Taylor, P., and DeBierve, P., 2002, Compilation of minimum and maximum isotope ratios of selected elements in naturally occurring terrestrial materials and reagents: U.S. Geological Survey WaterResources Investigations Report 2001-4222, 98 p., https://pubs.er.usgs.gov/publication/wri014222.

Davis, T.A., Kulongoski, J.T., and Belitz, Kenneth, 2013, Groundwater-quality data in Santa Barbara study unit, 2011-Results from the California GAMA Program: U.S. Geological Survey Data Series 742, 72 p., https://pubs.er.usgs.gov/publication/ds742.
Dwyer, G.S., and Vengosh, Avner, 2008, Alternative filament loading solution for accurate analysis of boron isotopes by negative thermal ionization mass spectrometry: American Geophysical Union, Fall Meeting, abstract \#H51C-0824.

Eaton, G.F., Hudson, G.B., and Moran, J.E., 2003, Tritiumhelium-3 age-dating of groundwater in the Livermore Valley of California: American Chemical Society ACS Symposium Series, v. 868, p. 235-245, http://pubs.acs.org/doi/abs/10.1021/bk-2004-0868.ch016.

Kulongoski, J.T., and Hilton, D.R., 2011, Applications of Groundwater Helium, Chapter 15 in Baskaran, M., ed., Handbook of Environmental Isotope Geochemistry: Springer-Verlag, p. 285-304.

Moran, J.E., Hudson, G.B., Eaton, G.F., and Leif, Roald, 2002, A contamination vulnerability assessment for the Livermore-Amador and Niles Cone Groundwater Basins: Lawrence Livermore National Laboratory internal report UCRL-AR-148831, 25 p., http://www.waterboards.ca.gov/water_issues/programs/ gama/docs/cas_1lnl_alameda.pdf.

U.S. Geological Survey, 2004, Resources on isotopesPeriodic table-Boron: U.S. Geological Survey Isotopic Tracers Project, accessed June 23, 2015, at http://wwwrcamnl.wr.usgs.gov/isoig/period/b_iig.html.

Vengosh, Avner, Chivas A.R., and McCulloch M.T., 1989, Direct determination of boron and chlorine isotope compositions in geological materials by negative thermal-ionization mass spectrometry: Chemical Geology, v. 79, no. 4, p. 333-343, http://dx.doi.org/10.1016/0168-9622(89)90039-0. 
Table 3-1. Results for analyses of noble gases by the Lawrence Livermore National Laboratory (LLNL) and modeled recharge temperatures for samples collected for the Santa Barbara study unit, 2011, California Groundwater Ambient Monitoring and Assessment (GAMA) Priority Basin Project.

[The five digit number in parentheses below the constituent name is the U.S. Geological Survey parameter code used to uniquely identify a specific constituent or property. Measurement errors: Helium-3/helium-4 ratios, helium-4, argon, neon, and xenon have average errors of 2-percent; krypton and xenon have average errors of 3-percent; errors for modeled recharge temperatures are less than $0.5^{\circ} \mathrm{C}$ for all samples. Abbreviations: $\mathrm{cm}^{3} \mathrm{STP} / \mathrm{gH}_{2} \mathrm{O}$, cubic centimeters per gram at standard temperature and pressure; na, not available; ${ }^{\circ} \mathrm{C}$, degrees Celsius]

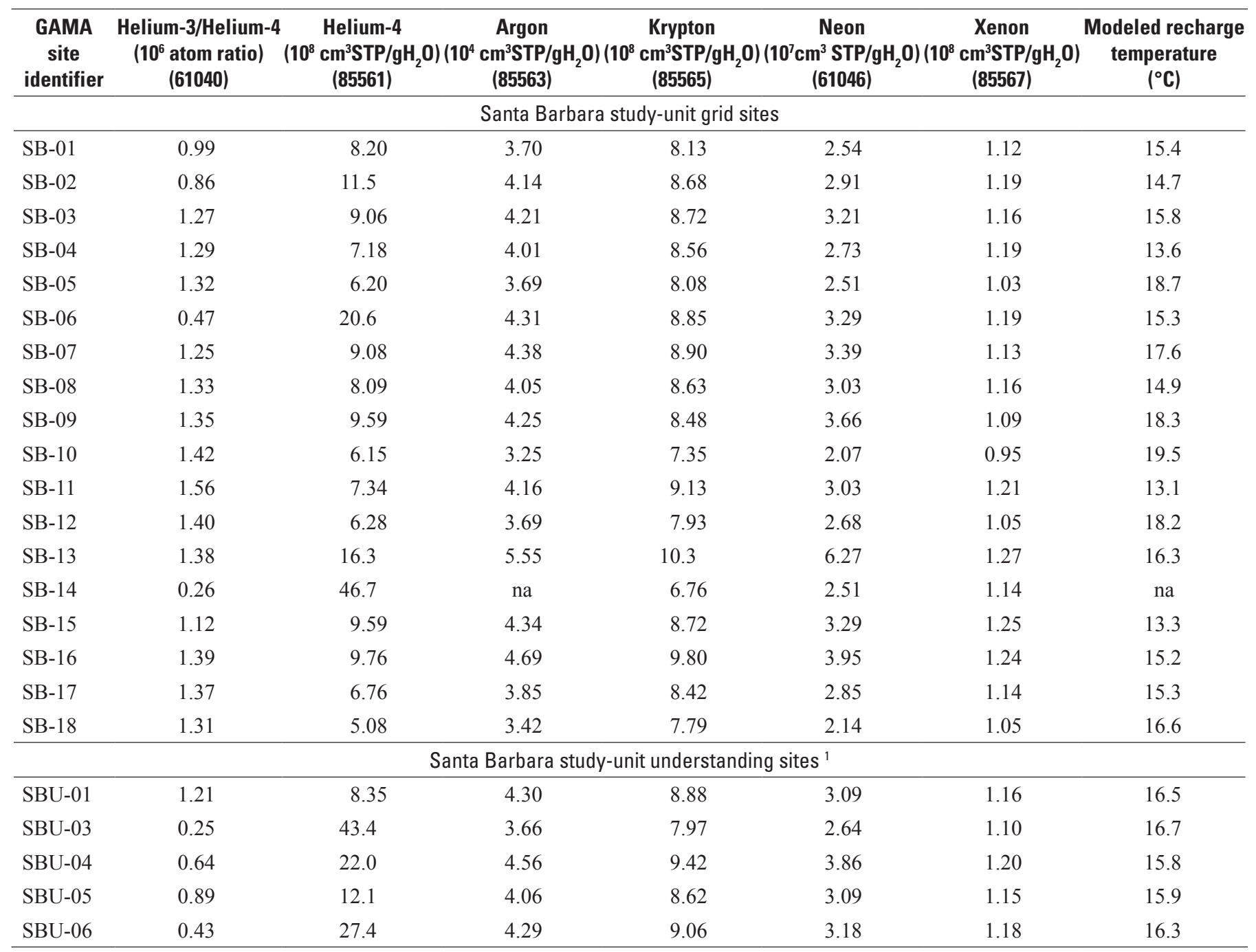

\footnotetext{
${ }^{1}$ No results were reported for SBU-02.
} 
Table 3-2. Results for isotopic analyses of boron and strontium in water by the U.S. Geological Survey (USGS) National Research Program (NRP) Metals Isotope Research Laboratory for samples collected for the Santa Barbara study unit, 2011, California Groundwater Ambient Monitoring and Assessment (GAMA) Priority Basin Project.

[The five digit number in parentheses below the constituent name is the U.S. Geological Survey parameter code used to uniquely identify a specific constituent or property. Stable isotope ratios of boron are reported in delta notation $\left(\delta^{11} \mathrm{~B}\right)$, the ratio of a heavier isotope to the lighter isotope of the element relative to the National Institute of Standards and Technology (NIST) reference material SRM 951 boric acid, which is assigned a $\delta^{11} \mathrm{~B}$ value of 0 per mil (parts per thousand; Coplen and others, 2002). Isotopic ratios of strontium $\left({ }^{87} \mathrm{Sr} /{ }^{86} \mathrm{Sr}\right)$ are reported as the abundance of atoms of the heavier isotope to the lighter isotope of the element.]

\begin{tabular}{|c|c|c|}
\hline $\begin{array}{c}\text { GAMA } \\
\text { site } \\
\text { identifier }\end{array}$ & $\begin{array}{c}\delta^{11 B} \mathrm{~B} \\
\text { (per mil) } \\
\text { (62648) }\end{array}$ & $\begin{array}{c}\text { Strontium isotope ratio } \\
\left({ }^{87} \mathrm{Sr}{ }^{\beta 6} \mathrm{Sr}\right) \\
(\text { atom ratio) } \\
(75978)\end{array}$ \\
\hline \multicolumn{3}{|c|}{ Santa Barbara study-unit grid sites } \\
\hline SB-01 & 3.25 & 0.7088 \\
\hline SB-02 & 18.61 & 0.7093 \\
\hline SB-03 & 8.24 & 0.7095 \\
\hline SB-04 & 9.07 & 0.7092 \\
\hline SB-05 & 19.48 & 0.7098 \\
\hline SB-06 & 17.98 & 0.7093 \\
\hline SB-07 & 18.23 & 0.7093 \\
\hline SB-08 & 11.49 & 0.7096 \\
\hline SB-09 & 15.98 & 0.7095 \\
\hline SB-10 & 38.88 & 0.7095 \\
\hline SB-11 & 9.16 & 0.7097 \\
\hline SB-12 & 20.31 & 0.7099 \\
\hline SB-13 & 19.48 & 0.7100 \\
\hline SB-14 & 4.37 & 0.7103 \\
\hline SB-15 & 14.24 & 0.7100 \\
\hline SB-16 & 15.73 & 0.7100 \\
\hline SB-17 & 14.49 & 0.7097 \\
\hline SB-18 & 14.99 & 0.7096 \\
\hline \multicolumn{3}{|c|}{ Santa Barbara study-unit understanding sites } \\
\hline SBU-01 & 16.98 & 0.7096 \\
\hline SBU-02 & 26.22 & 0.7099 \\
\hline SBU-03 & 20.40 & 0.7096 \\
\hline SBU-04 & 16.86 & 0.7096 \\
\hline SBU-05 & 16.57 & 0.7097 \\
\hline SBU-06 & 17.40 & 0.7096 \\
\hline
\end{tabular}


Publishing support provided by the U.S. Geological Survey Science Publishing Network, Sacramento Publishing Service Center

For more information concerning the research in this report, contact the Director, California Water Science Center

U.S. Geological Survey

6000 J Street, Placer Hall

ISSN 2328-031X (print)

Sacramento, California 95819

http://dx.doi.org/10.3133/sir20165112

http://ca.water.usgs.gov 

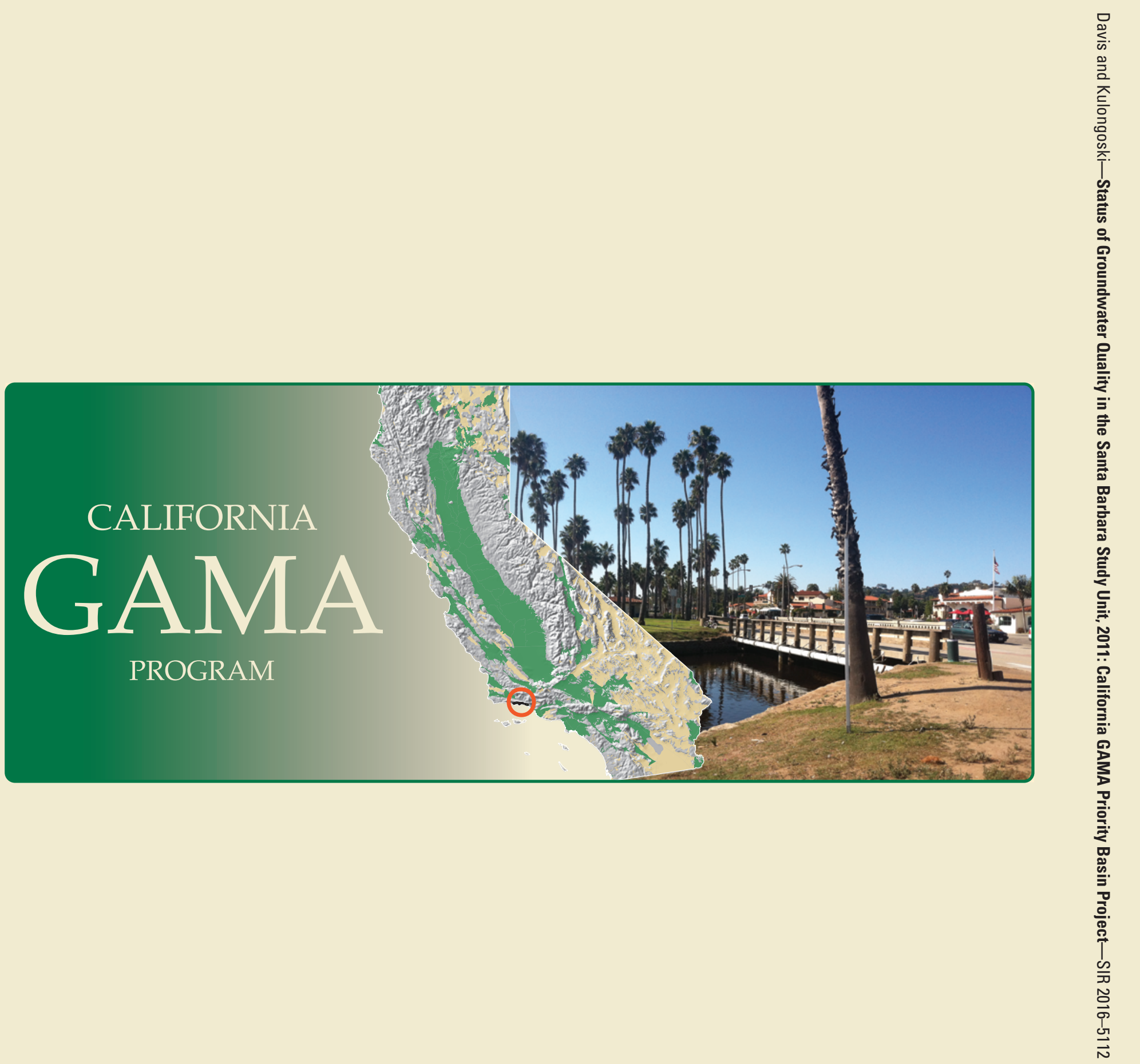